\title{
The relationship between $R \& D$ partnership formation, social embeddedness and innovative performance : a multi-level approach of social embeddedness
}

Citation for published version (APA):

Cloodt, D. A. M. (2008). The relationship between R\&D partnership formation, social embeddedness and innovative performance : a multi-level approach of social embeddedness. [Doctoral Thesis, Maastricht University]. Universitaire Pers Maastricht. https://doi.org/10.26481/dis.20080618dc

Document status and date:

Published: 01/01/2008

DOI:

10.26481/dis.20080618dc

Document Version:

Publisher's PDF, also known as Version of record

Please check the document version of this publication:

- A submitted manuscript is the version of the article upon submission and before peer-review. There can be important differences between the submitted version and the official published version of record.

People interested in the research are advised to contact the author for the final version of the publication, or visit the DOI to the publisher's website.

- The final author version and the galley proof are versions of the publication after peer review.

- The final published version features the final layout of the paper including the volume, issue and page numbers.

Link to publication

\footnotetext{
General rights rights.

- You may freely distribute the URL identifying the publication in the public portal. please follow below link for the End User Agreement:

www.umlib.nl/taverne-license

Take down policy

If you believe that this document breaches copyright please contact us at:

repository@maastrichtuniversity.nl

providing details and we will investigate your claim.
}

Copyright and moral rights for the publications made accessible in the public portal are retained by the authors and/or other copyright owners and it is a condition of accessing publications that users recognise and abide by the legal requirements associated with these

- Users may download and print one copy of any publication from the public portal for the purpose of private study or research.

- You may not further distribute the material or use it for any profit-making activity or commercial gain

If the publication is distributed under the terms of Article $25 \mathrm{fa}$ of the Dutch Copyright Act, indicated by the "Taverne" license above, 
THE RELATIONSHIP BETWEEN R\&D PARTNERSHIP FORMATION, SOCIAL EMBEDDEDNESS AND INNOVATIVE PERFORMANCE

\author{
A MULTI-LEVEL APPROACH OF SOCIAL EMBEDDEDNESS
}


The relationship between R\&D partnership formation, social embeddedness and innovative performance: a multi-level approach of social embeddedness

C D.A.M. Cloodt, Sittard 2008

Proefschrift Universiteit Maastricht

ISBN 978-90-5278-722-0

All rights reserved. No part of this publication may be reprinted or utilized in any form or by any electronic, mechanical or other means, now known, or hereafter invented, including photocopying and recording, or in any information storage or retrieval system, without written permission from the copyright owner.

Cover photography: "Dandelion Dew", Taro Taylor, www.flickr.com/photos/tjt195/

Remixed by: Daniëlle Cloodt

License terms: http://creativecommons.org/licenses/by-nc/2.0/

Cover design: Daniëlle Cloodt

Printed by: Datawyse / Universitaire Pers Maastricht 


\section{THE RELATIONSHIP BETWEEN R\&D PARTNERSHIP FORMATION, SOCIAL EMBEDDEDNESS AND INNOVATIVE PERFORMANCE}

A MULTI-LEVEL APPROACH OF SOCIAL EMBEDDEDNESS

\section{PROEFSCHRIFT}

TER VERKRIJGING VAN DE GRAAD VAN DOCTOR

AAN DE UNIVERSITEIT MAASTRICHT,

OP GEZAG VAN DE RECTOR MAGNIFICUS, PROF. MR. G.P.M.F. MOLS VOLGENS HET BESLUIT VAN HET COLLEGE VAN DECANEN,

IN HET OPENBAAR TE VERDEDIGEN

OP WOENSDAG 18 JUNI 2008 OM 14.00 UUR

DOOR

DANIËLLE ANNA MARIA CLOODT

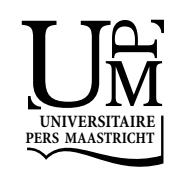




\section{Promotor}

Prof. dr. J. Hagedoorn

\section{Copromotor}

Prof. dr. H.L. van Kranenburg (Radboud Universiteit Nijmegen)

\section{Beoordelingscommissie}

Prof. dr. M.A. Carree (voorzitter)

Prof. dr. A.P. de Man (Vrije Universiteit Amsterdam)

Prof. dr. P. Mohnen 
"Kolen branden dicht op elkaar,

als ze zich afscheiden doven ze."

(Boeddhistisch spreekwoord)

\author{
Voor Robert,
}

Mam en Pap,

Myriam

en Oma

“... these are the ties that bind!" 


\section{Dankwoord (Acknowledgements in Dutch)}

"Everyone is a new door opening into other worlds. Six degrees of separation between us and everyone else on this planet. But, to find the right six people..." (quote from Ouisa Kittredge in the film Six Degrees of Separation by Fred Schepisi)

Dit proefschrift is voortgekomen uit de gedachte dat sociale inbedding bepalend is voor het vormen van nieuwe netwerkbanden evenals het verhogen van innovatief succes. Ik besef goed dat dit proefschrift niet tot stand was gekomen zonder de hulp van "mijn eigen netwerkbanden". Succes heb je immers niet alleen, dat maak je met elkaar. Ik wil iedereen bedanken die heeft bijgedragen aan dit proefschrift door informatie, kennis en ideeën met mij uit te wisselen, waardoor ik (hopelijk) in staat ben geweest om te leren, inzichten te ontwikkelen en vernieuwend bezig te zijn.

Een aantal mensen wil ik hier in het bijzonder bedanken. Allereerst mijn promotor John Hagedoorn, die ondanks zijn drukke agenda altijd tijd wist vrij te maken om mijn onderzoek te bespreken, zeer zorgvuldig de hoofdstukken te lezen en (door middel van vele rode penstrepen) van waardevol commentaar en opbouwende kritiek te voorzien. Tevens wist hij bruikbare ideeën en oplossingen aan te dragen. Zijn uitstekende academische kennis en ervaring waren onmisbaar voor dit onderzoek, ik heb dan ook veel van hem geleerd. John, het was steeds weer een voorrecht om met jou van gedachten te mogen wisselen. Bedankt voor je enthousiasme en vertrouwen. Ook wil ik mijn copromotor Hans van Kranenburg bedanken. Hans, bedankt voor je waardevolle feedback en je deskundigheid ten aanzien van mijn onderzoek. Tevens wil ik je bedanken voor de kans die je me hebt geboden om me verder te ontplooien als universitair docent binnen de afdeling Strategie \& Marketing aan de Radboud Universiteit in Nijmegen. John en Hans, jullie unieke academische vaardigheden en bekwaamheden sluiten mooi op elkaar aan en waren essentieel gedurende het gehele onderzoeksproces. Bedankt voor het vertrouwen in onze (toekomstige) samenwerking.

Eveneens een woord van dank aan mijn beoordelingscommissie: Martin Carree, Pierre Mohnen en Ard-Pieter de Man, voor de tijd en moeite die zij genomen hebben om mijn proefschrift te lezen en te beoordelen.

Ik bedank mijn voormalige collega's van de Universiteit Maastricht en in het bijzonder de collega's van Organisatie \& Strategie voor hun betrokkenheid bij mijn onderzoek en voor de gezelligheid. Ik wil vooral Marc van Ekert bedanken voor het aanleveren van de data en voor zijn bereidwillige hulp en uitleg met betrekking tot het inlezen van data in verschillende computerprogramma's en het bewerken van data door middel van allerlei queries; de voormalige student-assistenten Kim Wolters, Sonia Pardal de Sousa en Margo Hoogenberk voor hun medewerking aan de verzameling van data; mijn voormalige kamergenoten Hans Frankort en Andrea Günster voor de interesse in mijn onderzoek en voor de gezelligheid en de goede sfeer op onze kamer tijdens het laatste 
jaar van mijn aio-schap; Kitty van Straaten, Adela Buttolo en Eva Nelissen voor hun hulp bij het regelen van allerlei zaken van organisatorische aard evenals voor de plezierige gesprekken op het secretariaat en mijn mede-aio's voor hun betrokkenheid en gezelligheid: "you're next!" Verder wil ik alle leden van het beruchte champagnecomité bedanken voor de leuke borrels in d'Ouwe Klok (de Wekker) en de Tribunal. Als laatste een woord van dank aan mijn collega's van de RU, in het bijzonder de afdeling Strategie \& Marketing voor hun belangstelling in mijn onderzoeksproject, de lunches en de gezellige gesprekken.

Zonder mijn "eigen sociaal netwerk" bestaande uit familie, vrienden en kennissen had ik deze drukke en soms stressvolle periode nooit volbracht. Ik wil al mijn vrienden en kennissen bedanken voor de nodige afleiding, er bestaat immers gelukkig ook nog een leven naast het aio-schap. In het bijzonder wil ik Simone Franssen, Petra KramerOgrajensek en Anita Gidding-Baade bedanken. We kennen elkaar al sinds de middelbare school, bedankt voor de gezellige uitstapjes en borrels, en voor jullie vriendschap. Mirella Kleijnen, de voorbereidingen voor het promotiefeest van Myriam waren vaak hilarisch, bedankt dat je ook mijn paranimf wilt zijn.

Ten slotte een woord van dank aan mijn familie en (toekomstige) schoonfamilie en in het bijzonder aan de vijf personen aan wie dit boek is opgedragen: Robert, mam en pap, Myriam en oma. Oma, "op dé centrale positie in ons familienetwerk", bedankt voor uw liefde en betrokkenheid bij hetgeen waar ik mee bezig was.

Myriam, "mijn grote zus", je hebt me bij zowat alles geholpen waar het maar kon. Gedurende de gehele fase van mijn proefschrift heb jij een belangrijke rol gespeeld. Bedankt voor je hulp, enthousiasme, vriendschap en liefde. Jij bent niet voor niets één van mijn paranimfen!

Lieve mam en pap, jullie hebben mij altijd gestimuleerd om er uit te halen wat er in zit en staan daarmee aan de basis van dit proefschrift. Bedankt voor jullie begrip, vertrouwen, steun en onvoorwaardelijke liefde. Jullie staan altijd voor me klaar!

Lieve Robert, jij kwam mijn leven binnenstappen op het moment dat ik net was begonnen aan mijn proefschrift. Jouw vertrouwen in mij en in dit proefschrift en jouw eindeloos geduld gedurende vooral de laatste maanden van de afronding van dit proefschrift hebben ervoor gezorgd dat ik de finish uiteindelijk gehaald heb. Onze "strong tie" is heel bijzonder en uniek! Ik houd oneindig veel van je! Op naar de volgende feesten: onze bruiloft en jouw promotie! 


\section{CONTENTS}

\section{Acknowledgements (in Dutch)}

1 Introduction 1

1.1 Introduction 1

1.2 Theoretical background 2

1.3 Research questions 5

1.4 Reasons for selecting R\&D partnerships in high-tech industries 7

1.5 Outline of the book 9

2 International inter-firm R\&D partnership formation: an overview of 13 major trends and patterns (1971-2000)

$\begin{array}{lll}2.1 & \text { Introduction } & 13\end{array}$

2.2 International R\&D partnerships: definition, their rationale and 14 organizational settings

2.3 General patterns in international R\&D partnerships $\quad 16$

$\begin{array}{lll}2.4 & \text { Sectoral patterns in international R\&D partnerships } & 18\end{array}$

2.5 Patterns in international R\&D partnerships of companies from 24 different economic regions

$\begin{array}{ll}2.6 \text { Conclusions } & 29\end{array}$

3 Intellectual property rights and the governance of international 31 R\&D partnerships

3.1 Introduction 31

3.2 Theory and hypotheses $\quad 32$

$\begin{array}{lll}3.3 & \text { Research methods } & 37\end{array}$

$\begin{array}{lll}3.4 & \text { Results } & 40\end{array}$

3.5 Discussion $\quad 43$

3.6 Conclusions 45

4 Multi-causal relationships between R\&D partnership formation, 47 positional embeddedness and innovative performance

$\begin{array}{lll}4.1 & \text { Introduction } & 47\end{array}$

4.2 R\&D partnership formation and innovative performance $\quad 50$

4.3 Positional embeddedness $\quad 52$

4.4 Introducing multiple causal relationships $\quad 55$

4.5 Research methods $\quad 56$

$\begin{array}{lll}4.6 & \text { Results } & 61\end{array}$

4.7 Discussion and conclusions 66 
5 The strength of R\&D network ties in high-tech industries: a multi- 71 dimensional analysis of the effects of tie strength on technological performance

5.1 Introduction

5.2 Theoretical background

$\begin{array}{lll}5.3 & \text { The measurement of tie strength } & 75\end{array}$

$\begin{array}{ll}5.4 & \text { Research methods } \\ 5.5 & 78\end{array}$

$\begin{array}{lll}5.5 & \text { Results } & 83\end{array}$

5.6 Discussion and conclusions $\quad 89$

6 Conclusions $\quad 93$

6.1 Introduction 93

6.2 Some major findings of this thesis and answer to the general 95 research question

6.3 Methodological, empirical, theoretical and managerial implications 101

$\begin{array}{ll}6.4 & \text { Limitations and suggestions for future research } \\ \end{array}$

$\begin{array}{ll}\text { Appendices } & \mathbf{1 0 8}\end{array}$

A The MERIT Cooperative Agreements and Technology Indicators 108 (CATI) Database

B The United States Patent and Trademark Office (USPTO) Database 109

$\begin{array}{ll}\text { References } & 110\end{array}$

$\begin{array}{ll}\text { Summary in Dutch (Nederlandse samenvatting) } & 125\end{array}$

$\begin{array}{ll}\text { Curriculum Vitae } & 132\end{array}$ 


\section{LIST OF TABLES}

2.1 Relative contractual partnering indexes of all sectors (1971-2000)

3.1 Descriptive statistics (means and standard deviations (S.D.)) and 41 bivariate correlations for all variables, $\mathrm{N}=2005$

3.2 Estimation results of the binomial logit analysis

4.1 Descriptive statistics (means and standard deviations (S.D.)) and 62 bivariate correlations among explanatory and control variables

4.2 The effect of R\&D partnership formation on positional embeddedness: results of the negative binomial analysis

4.3 The effect of innovative performance and positional embeddedness on 64 R\&D partnership formation: results of the negative binomial analysis

4.4 The effect of R\&D partnership formation and positional embeddedness 65 on innovative performance: results of the negative binomial analysis

4.5 Descriptive statistics (means and standard deviations (S.D.)) and 66 bivariate correlations between the residuals of the three negative binomial analyses

5.1 Descriptive statistics (means and standard deviations (S.D.)) and 84 bivariate correlations for all variables of the exploratory factor analysis

5.2 Estimation results of the exploratory factor analysis 84

5.3 Descriptive statistics (means and standard deviations (S.D.)) and 85 bivariate correlations for all variables of the negative binomial analysis

5.4 Estimation results of the negative binomial analysis (one year lead time 86 for the dependent variable)

5.5 Estimation results of the negative binomial analysis (two years lead time 87 for the dependent variable)

5.6 Estimation results of the negative binomial analysis (three years lead 88 time for the dependent variable) 


\section{LIST OF FIGURES}

1.1 Overview of the thesis and the specific research questions 8

2.1 The growth of newly established international R\&D partnerships (1971- 16 2000)

2.2 The share (\%) of joint ventures in all newly established international 18 R\&D partnerships (1971-2000)

2.3 The share (\%) of high-tech, medium-tech, and low-tech industries in all 19 newly established international R\&D partnerships (1971-2000)

2.4 The share (\%) of high-tech industries in all newly established 20 international R\&D partnerships (1971-2000)

2.5 Relative contractual partnering indexes, per sector (1971-2000) 23

2.6 Distribution of newly established international R\&D partnerships, 25 economic regions (1971-2000)

2.7a Distribution of newly established international R\&D partnerships, 26 economic regions (1971-2000)

2.7b Distribution of newly established international R\&D partnerships, 27 economic regions (1971-1980)

2.7c Distribution of newly established international R\&D partnerships, 27 economic regions (1981-1990)

2.7d Distribution of newly established international R\&D partnerships, 28 economic regions (1991-2000)

4.1 The multiple causal relationships between R\&D partnership formation, 49 positional embeddedness and innovative performance

6.1 Multi-level approach of a firm's social embeddedness 



\section{CHAPTER 1}

\section{INTRODUCTION}

\subsection{Introduction}

In recent decades, a number of environmental shifts have led to fundamental changes in the structure of the global economy and to an ongoing process of technological change and convergence, thereby leading to new opportunities for inter-firm cooperation. Examples of these shifts are, for instance, homogenization and globalization of markets, regulatory changes, and fierce competition. Whereas everincreasing uncertainty and costs of research and development (R\&D) and the increasing complexity of products combined with a strong increase in the speed of technological developments are the main drivers from a technological perspective (Contractor and Lorange, 1988; Dussauge and Garrette, 1999; Hagedoorn, 1993, 1996; Haklisch, 1989; Mowery, 1988; Mytelka, 1991; Nooteboom, 1999; OECD, 1992).

Traditionally, firms have been understood as independent and self-contained units, organizing R\&D internally and relying on outside contract research only for relatively simple functions or products (Mowery, 1983; Nelson, 1990). However, during the seventies and early eighties, a number of companies started to replace their traditional practices, such as mergers and foreign direct investment, with new forms of organization, such as joint ventures, joint development agreements, and other types of partnerships (Duysters and Hagedoorn, 2000).

R\&D partnerships are part of a relatively large and diverse group of inter-firm relationships that one finds in between standard market transactions of unrelated companies and integration by means of mergers and acquisitions (Hagedoorn, 2002). R\&D partnerships can be defined as a specific set of different modes of innovationbased inter-firm collaboration where two or more firms, which remain independent economic agents and organizations, share part of their R\&D activities (see for instance Hagedoorn, 2002; Hagedoorn, Link and Vonortas, 2000).

R\&D partnerships can be divided into two categories, i.e. contractual (nonequity) agreements, such as joint $R \& D$ pacts and joint development agreements, and equity based partnerships, such as joint ventures. Joint ventures are organizational units created and controlled by two or more parent companies, thereby increasing the organizational interdependence of the parent companies (Hagedoorn, 2002). Joint ventures, including those with a specific R\&D program, are one of the older modes of inter-firm partnering and have become well known during the past decades (Berg et al., 1982; Hagedoorn, 1996; Hladik, 1985). According to Hagedoorn (1996) and Narula and Hagedoorn (1999), equity based partnerships such as joint ventures seem to have become gradually less popular if compared to other forms of partnering due to 
their organizational costs in combination with high failure rate (Kogut, 1988; Porter, 1987).

Contractual agreements cover technology and R\&D sharing between two or more companies in combination with joint research or joint development projects (Hagedoorn, 2002). The costs are shared between the partners. The organizational dependence between companies in a contractual R\&D partnership is smaller compared to equity-based partnerships and the time-horizon of the actual project-based partnership is almost by definition shorter (Hagedoorn, 1993). These contractual forms of R\&D partnerships have become very important modes of inter-firm collaboration as their share has far exceeded that of joint ventures (Hagedoorn, 2002; Narula and Hagedoorn, 1999; Osborn and Baughn, 1990).

Reasons for engaging into these partnerships are, among others, uncertainty and risk reduction, reducing innovation time span, access to new (product) markets (in the case of limited international experience), governmental restrictions, access to (external) knowledge, technology and R\&D (especially because of increased technological complexity), the need to reduce, minimize and share costs, economies of scale, product rationalization, and co-opting or blocking competition (Eisenhardt and Schoonhoven, 1996; Hagedoorn, 1993; Haklisch, 1986; Harrigan, 1985, 1988; Hladik, 1985, 1988; Narula, 1996; Ohmae, 1985).

The above mentioned reasons can be distinguished into two broad categories of motives for engaging into R\&D partnership agreements (Narula, 1996). The first one, the cost economizing motive, focuses on transaction costs and production costs (depending on, for instance, economies of scale and scope) (Gulati and Singh, 1998; Spence, 1984). Secondly, R\&D partnership agreements must include some organizational interdependence between the firms involved, such that there is a strategic benefit that accrues to either partner as the result of shared capital, technology or other resources. There must be some expected long-term positive effects of the agreements on the product-market positioning of at least one of the partners (Hagedoorn, 1993). In reality, R\&D agreements are often both strategically motivated as well as cost-economizing, although some agreements are clearly biased towards one motivation (Narula, 1996).

In order to help us to position the topic of this dissertation within the proper theoretical context, a theoretical background is given in Section 1.2. We will introduce the research questions that form the center of each of the core chapters in this thesis in Section 1.3. Section 1.4 clarifies the most important reasons for selecting R\&D partnerships in high-tech industries, as the primary industrial context of our analysis. Finally, in Section 1.5 we will discuss the outline of the remainder of this thesis.

\subsection{Theoretical background}

Engaging into alliances has become more and more important during the last decades. However, not only the number of one-on-one alliances has become greater but firms 
are also increasingly embedded in networks of alliances (De Man, 2004). The main purpose of this thesis is to gain a better insight into the relationships between the formation of new R\&D partnerships, firm's social embeddedness and its innovative performance. To study these relationships, we make use of the theory of the firm (resource based view, dynamic capabilities view, and knowledge based view) and social network theory as important theoretical tools for identifying sources of competitive advantage in inter-organizational networks by reconciling some of the competing arguments surrounding how social embeddedness influences R\&D partnership formation and the innovative performance of individual firms. In line with social network theory, previous work introduced a differentiation of several levels of social embeddedness that affect the formation of new forms of economic organization such as inter-firm partnerships (Dacin et al., 1999; Granovetter, 1992; Gulati and Gargiulo, 1999; Hagedoorn, 2006; Hite, 2003; Lam, 1997, Simsek et al., 2003; Uzzi, 1997) and the innovative performance of the companies involved. This thesis makes use of a multi-level approach of social embeddedness to obtain more fine grained insights into the mechanisms driving R\&D partnership formation and innovative performance of firms. A distinction has been made between environmental embeddedness, positional embeddedness and relational embeddedness.

When considering the environmental embeddedness of inter-firm partnering, one can think of specific effects at the macro and meso level (Hagedoorn, 2006). The macro level of environmental embeddedness refers to specific country differences that influence the choice of governance in an international context. Although technological changes have fostered the homogenization and globalization of markets (Levitt, 1983), many companies are still to a large extent characterized by specific features that can be traced back to their country of origin. This type of embeddedness relates to the degree to which a company feels comfortable with the institutional environment of the home country of its partner. The more companies are embedded in the home country of their partner, the less likely they will choose for international R\&D partnerships that are characterized by strong government structures with hierarchical control, like joint ventures. Rather, these companies will prefer to engage into international R\&D partnerships that are characterized by looser structures with lower levels of hierarchical control, like joint R\&D pacts and joint development agreements or other contractual R\&D partnerships.

The meso level of environmental embeddedness refers to differences at the industry level that influence the choice of governance (Hagedoorn, 2006). Companies in high-tech industries appear to behave quite differently from companies in low-tech industries (OECD, 1992; Oster, 1992). There are differences with regard to the sectoral propensity to engage in partnerships (Hagedoorn, 1996; Link and Bauer, 1989; Mowery, 1988; Mytelka, 1991; OECD, 1992; Osborn and Baughn, 1990; Oster, 1992; Yu and Tang, 1992). These contributions conclude that high-tech industries account for a large share of inter-firm partnerships, and are willing to experiment with new forms of organization. This particular feature of some sectors implies that the opportunity to engage in $R \& D$ partnerships differs for a range of industries. The 
general picture that emerges from the above mentioned literature is that contractual agreements are particularly preferred in high-tech industries, i.e. sectors with high levels of technological change, whereas joint ventures play a role of disproportionate importance in other industries. Similar patterns for joint ventures and contractual alliances can be expected in R\&D partnering.

Positional embeddedness refers to the central position that a firm occupies within the alliance network. It is said that firms that occupy a central position within the alliance network have access to information and thereby to external knowledge from a greater number of partner firms as well as from a greater variety of firms. The above mentioned external knowledge generation is based on differences in technological capabilities between firms and is a central issue in research traditions that stress the importance of organizational learning and the transfer and diffusion of innovative capabilities within a company (Grant, 1996).

According to the knowledge-based view of the firm (Conner and Prahalad, 1996; Grant, 1996; Kogut and Zander, 1992; Nonaka, 1991; Nonaka and Takeuchi, 1995), heterogeneous knowledge bases and capabilities among firms are the major determinants of a sustainable competitive advantage and superior performance, which is especially relevant in rapidly changing environments like high-tech industries. Exposure to new ideas and new (external) knowledge increases the opportunities for organizational learning. Firms can learn from each other's differences in technological capabilities, generate new ideas and practices, generate new knowledge and create incentives for innovative behavior (Ahuja, 2000a; Baum, Calabrese and Silverman, 2000; Cohen and Levinthal, 1989, 1990; Knoke and Burt, 1983; Mody, 1993; Powell, Koput and Smith-Doerr, 1996; Stuart, 2000; Teece, 1992; Wasserman and Faust, 1994). So, besides engaging into one-on-one alliances, occupying positional embeddedness within the network is expected to have a positive effect on innovative performance of companies as well.

Relational embeddedness refers to the quality of specific dyadic relationships in pairs of related economic organizations, including the degree to which parties consider one another's needs and goals as well as the behaviors that they exhibit toward one another, such as trust, norms, reputation, sanctions, and obligations (Coleman, 1990; Simsek et al., 2003). Granovetter (1973) refers to relational embeddedness as the strength of dyadic ties that increases with "amount of time, emotional intensity, intimacy (mutual confiding) and reciprocity" engaged during the interaction between partners. This strength of network ties can be understood in terms of strong ties and weak ties.

Weaker ties are more likely to link companies to different local networks (Granovetter, 1973; Krackhardt, 1992), to connect distant companies with diverse and unique perspectives, different activities, and diverse problem-solving styles (Granovetter, 1982; Ruef, 2002), and to connect companies to a wider range of potential partners and more, non-redundant information (Burt, 1992; Granovetter, 1973, 1982; Weimann, 1983). Exposure to different approaches and new perspectives can enhance important innovative skills, thereby enhancing a company's technological 
performance (Feldman and Audretsch, 1999; Granovetter, 1982; Hagedoorn and Duysters, 2002a; Kogut, 2000; Liebeskind, Oliver, Zucker and Brewer, 1996; Ruef, 2002; Schilling and Steensma, 2001).

Interestingly, a small number of contributions seem to suggest exactly the opposite logic, where strong network ties of companies generate better results than weak ties. Strong ties may be beneficial, for instance by providing a strong social environment and mutual support for network players (Krackhardt, 1992) by providing relational trust and reciprocity in information exchange between partners (Larson, 1992; Soh, 2003). Relational trust affects the degree of information exchange (Jenssen and Koenig, 2002) and the degree to which companies can learn from their partnerships (Brass et al., 1998; Liebeskind et al., 1996; Kale, Singh and Perlmutter, 2000), thereby enabling organizations to better adapt to environmental changes as organizations with strong ties learn from their well-connected environment (Kraatz, 1998). Companies can use their strong ties to take advantage of joint learning and knowledge spillovers, while avoiding the duplication of innovative efforts, to improve their technological performance.

\subsection{Research questions}

Understanding the nature of a firm's social embeddedness by means of engaging into R\&D partnerships can aid us in comprehending the choice of governance made by firms. It also helps us in understanding how organizations gain new information and knowledge, thereby creating learning effects which are important in explaining firm innovative performance differences (Ghoshal, 1987; Hitt et al., 1996). Based upon the theoretical background as described above, the general research question in this thesis is therefore:

What is the relationship between a firm's $R \& D$ partnership formation, its social embeddedness and its innovative performance?

To answer this general research question we should answer several more specific subquestions. For our understanding of R\&D partnerships it is important to research the factors that influence the choice of governance. Previous research has presented an analysis of the choice between equity and contractual partnerships (Pisano, 1989; Oxley, 1999). These studies indicate that companies prefer to enter into an equitybased partnership rather than to engage in a contractual agreement when they are confronted with higher levels of specific knowledge transfer, when uncertainty surrounding partnerships increases and when small-number bargaining conditions create risk.

According to Hagedoorn (2006), environmental embeddedness, both in terms of country and industry specific contexts, can create a first understanding of differences with regard to the conduct of companies engaged in partnerships. When considering 
the macro level of environmental embeddedness, an important trend in recent decades is the ongoing process of globalization of markets, thereby leading to new opportunities for partnership formation. In the light of this, the role of intellectual property rights protection has increasingly become a relevant and important topic of research. By encouraging and facilitating creativity and innovation, and the dissemination of new ideas and creations, intellectual property rights protection is critical if innovative industries are to flourish. The degree to which country differences in intellectual property rights protection affect the choice of companies for a particular mode of international inter-firm R\&D partnering plays an important role when analyzing the macro level of environmental embeddedness.

Furthermore, when considering the meso level of environmental embeddedness, literature suggests that the level of technological change in industries might influence the preferred form of governance for partnering companies. Rapid technological change, (Harrigan, 1985, 1988) technological instability (Osborn and Baughn, 1990; Yu and Tang, 1992), and technological sophistication (Auster, 1987; Hagedoorn and Narula, 1996) in industries induces the formation of somewhat informal forms of R\&D partnering such as non-equity, contractual partnerships. Hence, when analyzing the meso level of environmental embeddedness, the degree to which sectoral technological change affects the choice of companies for a particular mode of international inter-firm $\mathrm{R} \& \mathrm{D}$ partnering plays an important role.

Positional embeddedness should be taken into consideration when analyzing R\&D partnership formation and innovative performance. A large amount of research has studied the relationships between R\&D partnerships, positional embeddedness and innovation. One of the important gaps in our understanding about these relationships result from the fact that most of these studies focus on singular causal relationships (see also Grodal, 2004) while using a specific dataset. In order to be able to "link" the different studies with each other and to be able to draw some conclusions from the body of studies as a whole, there is a need to investigate the relationships using one and the same dataset. Also, a joint consideration of R\&D partnership formation, positional embeddedness and innovative performance and their interaction, may provide us with more insight in the validity of the arguments made by previous authors such as for instance Powell et al. (1996) and Ahuja (2000a, 2000b).

Finally, relational embeddedness of firms deals with the strength of ties. The analysis of the effect of tie strength has had a profound impact on the current management and organization literature. Previous literature has analyzed these network ties in the context of individuals and small group behavior (Granovetter, 1973; Krackhardt, 1992). At the dyadic level, social network researchers have found advantages of both strong and weak ties to knowledge acquisition, and thereby to a firm's innovative performance. Although social network theory has also influenced the analysis of the behavior of companies and other organizations, there seems to be only a relatively small number of studies that concentrate specifically on the effect of strong and weak ties in an inter-organizational network setting (see also Jack, 2005). As already has been discussed, academic research about the impact of strong versus weak 
ties on the innovative performance of companies are inconclusive or contradicting each other. Much of the current literature on inter-organizational ties has taken a more one-dimensional perspective, which maybe could explain the contradicting results of the different studies. In an analysis of relational embeddedness in terms of the effect of strong or weak ties on the innovative performance of companies, there is a need for a more multi-dimensional approach of inter-firm network ties (see for instance McEvily and Zaheer, 1999).

In sum, the main research question can be divided into three more specific research questions (see Figure 1.1):

1. What is the effect of the macro level of environmental embeddedness (in terms of intellectual property rights protection) and the meso level of environmental embeddedness (in terms of the level of technological change in the sector of industry) on the preference of a company for hierarchical control in an international $R \& D$ partnership?

2. What are the effects of a company's R\&D partnership formation, positional embeddedness and innovative performance on each other?

3. What is the effect of relational embeddedness (in terms of strong and weak network ties) of a company on its innovative performance?

\subsection{Reasons for selecting R\&D partnerships in high-tech industries}

When analyzing the effect of environmental embeddedness on the choice of governance, we focus on international partnerships, because differences in intellectual property right protection regimes between partners are per definition only present in international partnerships. Our analysis will concentrate on a specific group of interfirm partnerships, i.e. international $R \& D$ partnerships, because in these joint $R \& D$ activities the protection of intellectual property rights is more crucial than in other forms of partnering such as standard customer-supplier relationships, second-sourcing or joint marketing agreements (Dussauge and Garette, 1999; Osborn and Baughn, 1990; Teece, 1986).

When analyzing the effect of positional as well as relational embeddedness on the innovative performance of a company, we will focus on R\&D partnerships (domestically as well as internationally) in high-tech industries. Although R\&D partnerships have become an important aspect of company behavior in a wide variety of industries, they play in particular an important role in high-tech industries where learning and flexibility are important features of the competitive landscape (Ciborra, 1991; Dussauge and Garrette, 1999; Eisenhardt and Schoonhoven, 1986; GomesCasseres, 1996; Harrigan and Newman, 1990; Oster, 1992). The literature also reveals that many $R \& D$ partnerships are concentrated in a limited number of mainly $R \& D$ intensive industries (Dussauge and Garrette, 1999; Hagedoorn and Schakenraad, 1993; Link and Bauer, 1989; Mytelka, 1991). 
Figure 1.1 Overview of the thesis and the specific research questions.

\begin{tabular}{l} 
Environmental Embeddedness: \\
Macro level: \\
Intellectual Property Rights Protection \\
Meso level: \\
Sectoral Technological Change \\
\hline
\end{tabular}
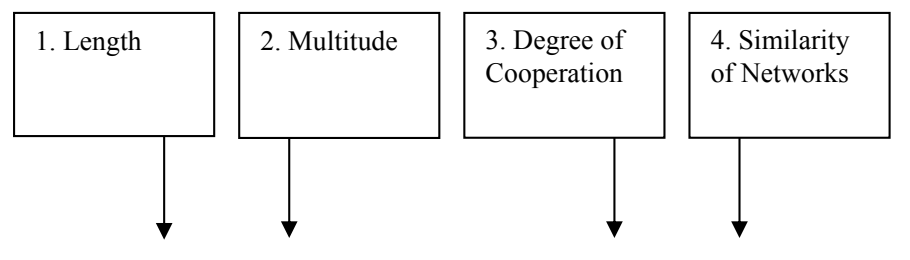

\begin{tabular}{|l|}
\hline 5. International \\
Cultural \\
Closeness \\
\hline
\end{tabular}

6. Domestic Partnership Formation
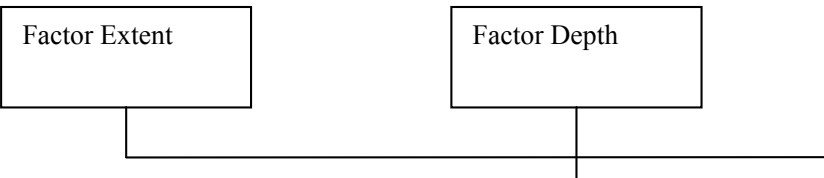

Factor Cultural Closeness

RQ 3.

(Ch. 5)

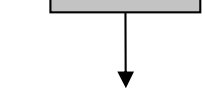

\section{Relational}

Embeddedness:

Tie Strength
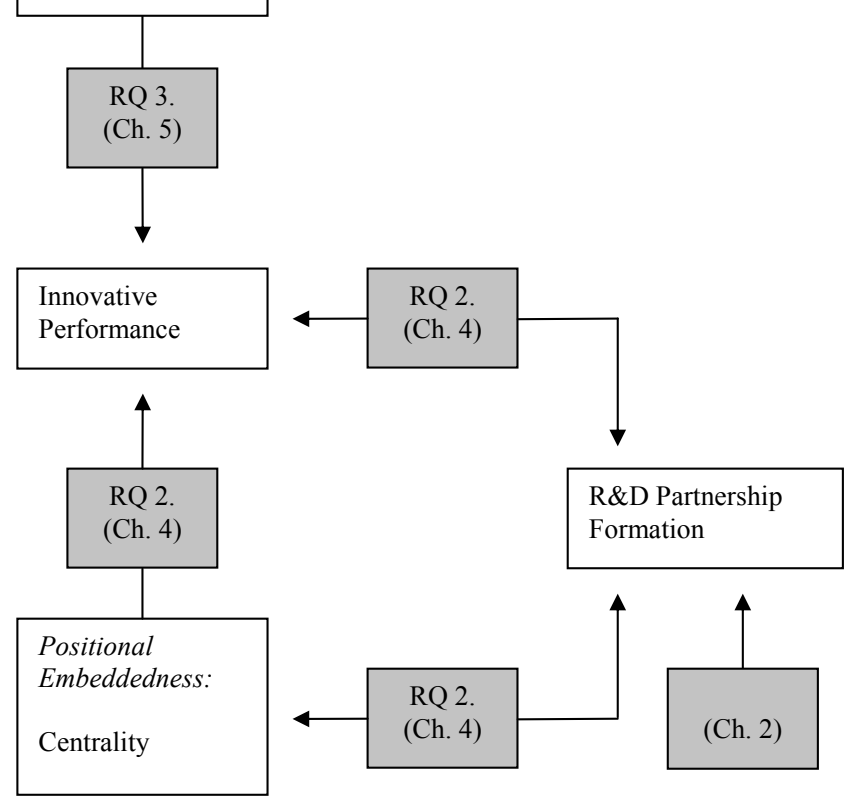
Following the standard OECD sector classification (OECD, 1997), the different sectors of industry can be classified into high-, medium- and low-tech industries using R\&D intensity indicators (i.e. R\&D expenditures as a percentage of value of production). Industries with $\mathrm{R} \& \mathrm{D}$ intensity indicators between $10 \%$ and $15 \%$ are considered to be high-tech industries, below $10 \%$ medium-tech industries and below $1 \%$ low-tech industries. Indeed, the importance of R\&D partnering by high-tech sectors has gradually increased over time, becoming the most dominant sector at the beginning of the 1980s and increasing in importance ever since. At the end of the millennium, more than $80 \%$ of all R\&D partnerships were established within the hightech sector. In particular the information technology sector $(50 \%$ share) and the pharmaceutical sector ( $30 \%$ share) play a very dominant role when it comes to $\mathrm{R} \& \mathrm{D}$ partnering within the high-tech sector (Hagedoorn, 2002).

Eisenhardt and Martin (2000) and Grant (1996) explain that particularly in rapidly changing environments, such as these high-tech industries, organizational learning and technological diversification are very important for effective innovative performance and the creation of a sustainable competitive advantage. In an environment in which technological innovation and the need for technological breadth is essential, companies will be more likely to form R\&D alliances in order to acquire new innovation capabilities. As demonstrated in a number of studies, high-tech industries are a major area of industrial activity where companies forge an increasing number of partnerships (Chung, Singh and Lee, 2000; Gomes-Casseres, 1996; Hagedoorn, 2002). It is also in these industries, where a large number of companies are engaged in joint R\&D through a variety of different modes of R\&D partnerships (Hagedoorn 1993; Soh, 2003). Therefore, this thesis will concentrate on R\&D partnerships within high-tech industries when analyzing the effect of (positional as well as relational) embeddedness on innovation.

\subsection{Outline of the book}

In Figure 1.1 an overview of the thesis and the specific research questions is provided. In order to obtain a better understanding of the phenomenon that is actually being studied, Chapter 2 introduces a historical analysis of the major trends and patterns in international R\&D partnerships for firms in the manufacturing sectors from 1971 to 2000. It discusses the historical importance and magnitude of international R\&D partnership formation from the beginning of the 1970s, together with some main rationales and definitions of international $R \& D$ partnerships to understand the phenomenon that is actually being studied. Thereafter, we present the general growth patterns, as well as the distribution of major organizational features of international R\&D partnerships. Next, specific sectoral growth patterns of international R\&D partnerships will be analyzed because partnerships are known to be somewhat sectorspecific as the propensity to enter into partnerships differs by industry. This is followed by an in-depth discussion of the growth patterns in international $R \& D$ 
partnerships of companies from different economic regions, as there are the developed economies (OECD), newly industrialized countries (NIC), and the less developed countries (LDC) which include the East European previously state-run economies and former communist countries (FCC).

Chapter 3 studies the effect of different regimes of intellectual property rights protection on the preference of companies for particular forms of international interfirm R\&D partnerships for a wide range of industries (including high-, medium- and low-tech industries) and for companies from a large number of countries by studying over 2000 international R\&D partnerships set up by nearly 2000 companies from 53 countries. Our research focuses on the period from the mid-1970s to the end of the 1990s when intellectual property rights protection, in particular patent-related property rights protection, appear to still diverge substantially between many countries at different levels of economic and technological development. Also, during that period many companies were still building up experience in international R\&D partnering with companies from countries with a less developed intellectual property rights regime. As such, each of these new partnerships can be seen as a crucial strategic decision. The research particularly looks at the choice for either equity based international $R \& D$ joint ventures or contractual international R\&D partnerships. In that context we will pay attention to a number of specific issues that refer to the international differences in intellectual property rights protection (at the macro level of environmental embeddedness) and the role that the level of technological change in industries (at the meso level of environmental embeddedness) might play in all of this.

Chapter 4 tries to develop an integral understanding of the relationships between R\&D partnerships, positional embeddedness and innovative performance. Previous research has treated the various relationships between alliance formation, positional embeddedness and innovation only in pairs thus far (thereby ignoring other relationships). Furthermore, the different studies investigating these various relationships all make use of a specific dataset. Following some recent suggestions for a more multiple causal approach (Grodal, 2004), this chapter will attempt to contribute to the previous literature by analyzing the multi-causal relationships and the resulting feedback loops between R\&D partnership formation, positional embeddedness and innovative performance of companies by using one and the same dataset. This dataset consists of a large international population of more than 3000 R\&D partnerships of nearly 1700 companies from 39 countries, established in 4 high-tech industries (pharmaceuticals including biotech, computers, semiconductors, and telecom) during the period 1990-2000.

Chapter 5 deals with relational embeddedness by investigating the effect of inter-firm R\&D network ties on the technological performance of companies in the above mentioned high-tech industries with the use of a large international population of more than 3000 R\&D partnerships of nearly 1700 companies from 39 countries, established in the above mentioned 4 high-tech industries during the period 19902000. A central question in that context is whether companies in high-tech industries should forge strong or weak ties with other companies through R\&D partnerships that 
can improve their innovative performance. Based on Granovetter's (1973) original contribution, tie strength is analyzed through a multi-dimensional perspective. Factor analysis is used to indicate the degree of coherence between the different dimensions of tie strength. The outcome of this partial analysis forms the basis of an index of the strength of different ties that preserves the multi-dimensional character of the strength of network ties.

Chapter 6 presents the conclusions of this thesis and provides an answer to our overall research question. In addition, this chapter will state the limitations of our study and offer some suggestions for future research. 



\section{CHAPTER $2^{1}$}

\section{INTERNATIONAL INTER-FIRM R\&D PARTNERSHIP FORMATION: AN OVERVIEW OF MAJOR TRENDS AND PATTERNS (1971-2000)}

\subsection{Introduction}

This chapter presents an analysis of major historical trends and sectoral patterns in international inter-firm R\&D partnering from 1971 to 2000 . The focus is on collaboration between independent companies through formal agreements, such as contractual agreements and joint ventures. We will mainly look at partnerships where $\mathrm{R} \& \mathrm{D}$ is at least part of the collaborative effort. It is well established that the ongoing process of globalization has greatly influenced the growth of these international interfirm R\&D partnerships. This is especially the case in technology intensive industries that undergo a process of rapid technological development. Increased global competition together with enlarged complexity of technology and the associated risks and costs of innovative activities have stimulated many firms to enter into international R\&D partnerships. In the following we will pay specific attention to differences between the developed economies (OECD), newly industrialized countries (NIC), less developed countries (LDC) which include the East European previously state-run economies and former communist countries (FCC).

The MERIT-CATI database (see Appendix A) will be used to discover a number of general trends and patterns in international R\&D partnering. This database is one of the few still existing databases that generate both cross-sectional and longitudinal insights. It allows us to study patterns in R\&D partnerships in several industries, in different regions of the world over an extended period of several decades (Hagedoorn, 2002; Hagedoorn et al., 2000).

The chapter is organized as follows: first, we will explain the rationale behind inter-firm partnering and provide some definitions. Second, we will give a general overview of trends in international R\&D partnerships since 1971, using the MERITCATI database. We will present growth data, as well as the distribution of major organizational features of international R\&D partnerships. Third, specific sectoral patterns of international $R \& D$ partnerships will be analyzed because partnerships are known to be somewhat sector-specific as the propensity to enter into partnerships

\footnotetext{
${ }^{1}$ This chapter is partly based on Cloodt, D. and J. Hagedoorn, 2005, The role of developing countries and emerging economies in international inter-firm R\&D partnering, in Cuyvers, L. and F. de Beule (eds.), Transnational corporations and economic development: from internationalization to globalization, London, Palgrave Macmillan, pp. 102-121. The focus of the above mentioned book chapter is on East European previously staterun economies and former communist countries. Therefore, this chapter has been extended in order to give an overview of trends and patterns in international inter-firm R\&D partnership formation from economies around the world.
} 
differs by industry. Fourth, we will present an in-depth discussion of the patterns in R\&D partnerships of companies from different economic regions. Finally, we will discuss some of the main conclusions that can be drawn from this contribution.

\subsection{International R\&D partnerships: definition, their rationale and organizational settings}

Traditionally, firms have been understood as independent and self-contained units. During the seventies and early eighties, however, a number of companies started to replace their traditional practices, such as mergers and foreign direct investment, with new forms of organization, such as joint ventures, joint development agreements, and other types of partnerships (Duysters and Hagedoorn, 2000). This process of change was triggered by fundamental changes in the structure of the global economy and by the ongoing process of technological change (Haklisch, 1989).

Strategic partnerships are often seen as an essential part of international corporate strategies (De Woot, 1990; Ohmae, 1990). It has been indicated in the literature that strategic partnerships can make up for the lack of economic power, competence, or foreign experience of at least one of the partners. Furthermore, they are also increasingly used as scanning devices that allow firms to monitor new markets without the need to invest the full amount of resources (Duysters and Hagedoorn, 2000).

This chapter focuses on international R\&D partnerships. We define $R \& D$ partnerships as the set of different modes of innovation-based inter-firm collaboration where two or more independent firms share part of their R\&D activities (see for instance Hagedoorn, 2002; Hagedoorn et al., 2000). These partnerships are expected to have an impact on the long-term product-market combinations of the companies involved. R\&D partnerships can be divided into two categories, i.e. contractual partnerships, such as joint R\&D pacts and joint development agreements, and equity based partnerships, such as joint ventures. Joint ventures are organizational units created and controlled by two or more parent companies, thereby increasing the organizational interdependence of the parent companies. Joint ventures, including those with a specific R\&D program, are one of the older modes of inter-firm partnering and have become well known during the past decades (Berg et al., 1982; Hagedoorn, 1996; Hladik, 1985). According to Hagedoorn (1996) and Narula and Hagedoorn (1999), joint ventures seem to have become gradually less popular if compared to other forms of partnering due to their organizational costs in combination with high failure rate (Kogut, 1988; Porter, 1987).

Contractual agreements cover technology and R\&D sharing between two or more companies in combination with joint research or joint development projects. The costs are shared between the partners. Although these contractual R\&D partnerships have a limited time-horizon, due to their project-based organization, each partnership appears to ask for a relatively strong commitment of companies and a solid inter- 
organizational interdependence during the joint project. Compared to joint ventures, however, the organizational dependence between companies in a contractual R\&D partnership is smaller and the time-horizon of the actual project-based partnership is almost by definition shorter (Hagedoorn, 1993). These contractual forms of R\&D partnerships have become very important modes of inter-firm collaboration as their share has far exceeded that of joint ventures (Hagedoorn, 2002; Narula and Hagedoorn, 1999; Osborn and Baughn, 1990).

The literature mentions two important categories of motives for engaging in inter-firm partnerships: the cost economizing motive and the strategic motive (see for instance Narula, 1996). The cost economizing motivation applies when at least one company enters the partnership mainly to lower the costs of some of its R\&D activities by sharing the costs with one or more other companies. This cost economizing rationale appears to particularly play a role in capital and $R \& D$ intensive industries where the costs of single, large R\&D projects are beyond the reach of many companies (Hagedoorn, 1993).

The strategic motive concerns organizational interdependence, such that there is a "strategic benefit" that accrues to either partner as the result of shared capital, technology or other resources. There must be some expected long-term positive effects of the agreement on the product-market positioning of at least one of the partners (Hagedoorn, 1993). Collaboration is seen as a means of shaping competition by improving a firm's comparative competitive position (Hagedoorn et al., 2000; Narula, 1996).

The strategic rationale becomes important if, for instance, companies decide to selectively enter into $R \& D$ partnerships that are not related to their core activities, while keeping their main R\&D activities within their own domain (Teece, 1986). The strategic intent of $R \& D$ partnerships is also apparent in those cases where companies jointly perform $R \& D$ in new, high-risk areas of $R \& D$ of which the future importance for their technological capabilities remains unclear for a considerable period of time.

As mentioned before, the reduction and sharing of costs of R\&D play an important role in the cost economizing rationale. The strategic rationale, however, lies rather in the reduction, minimizing, and sharing of uncertainty in R\&D. Other strategic motives that can be seen as driving factors behind the choice for engaging in a R\&D partnership are, among others, the increased complexity and intersectoral nature of new technologies, cross-fertilization of scientific disciplines and fields of technology, monitoring technological opportunities, monitoring of the evolution of technologies, technological synergies, and the access to scientific knowledge or to complementary technology (Hagedoorn, 1993). Other motives for participating in these research partnerships are found in gaining technical ability to diversify horizontally into new product lines, vertically integrate production activities, and leap-frog competitions within their primary line of business (Hagedoorn et al., 2000).

For many R\&D partnerships, however, cost economizing and strategic motives are intertwined, i.e. they are often both strategically motivated as well as cost economizing, although some agreements are clearly biased towards one motivation 
(Das et al., 1998; Eisenhardt and Schoonhoven, 1996; Hagedoorn, 1993; Hagedoorn et al., 2000, Lorenzoni and Lipparini, 1999; Mowery et al., 1998; Narula, 1996). However, it is important to realize that there is a dynamic aspect to all of this as the motives of a company can change over time due to developments in the company itself, its environment, and changes within the partnership (Harrigan, 1988).

\subsection{General patterns in international R\&D partnerships}

Previous research (Chesnais, 1988; Hagedoorn, 2002; Hergert and Morris, 1988; Hladik, 1985; Mariti and Smiley, 1983; OECD, 1986, 1992) has established that there is a small growth of inter-firm partnerships during the 1960s and 1970s. During the 1980 s, there seems to be a boom in the growth of inter-firm partnerships through all sorts of agreements. This general pattern is also found for the particular group of partnerships studied in this chapter, i.e. international R\&D partnerships (see Figure 2.1).

Figure 2.1 The growth of newly established international R\&D partnerships (1971-2000).

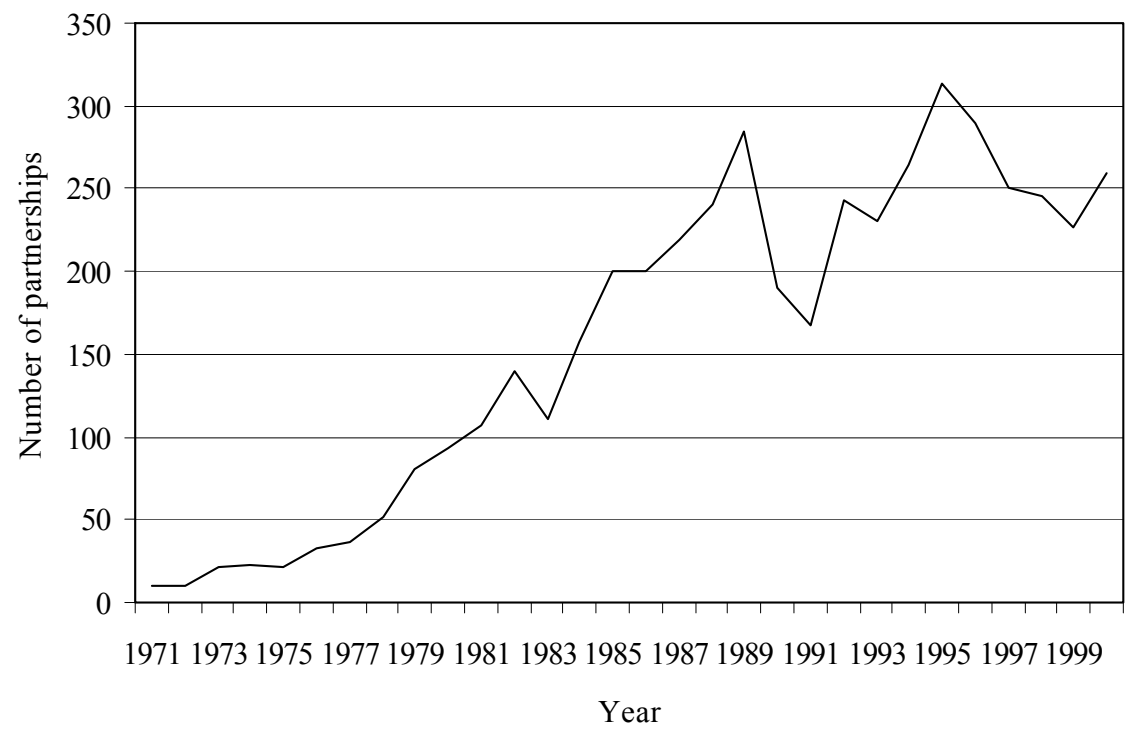

At the beginning of the 1970s the number of yearly established international R\&D partnerships, found in the MERIT-CATI database, remained at a low level of around fifteen made each year. Although these numbers are relatively small, they already attracted some attention in the literature, because this phenomenon puzzled academic observers (Hladik, 1985). Most of these partnerships were organized as joint ventures and the existing literature assumed that companies would simple exclude R\&D from joint ventures because of the risk involved in such sensitive activities. During the 
1970s there is a gradual increase in newly made international R\&D partnerships from around fifteen in the early 1970s to nearly twenty partnerships at the mid of the decade. At the end of the 1970 s there is a sudden increase to 80 new international R\&D partnerships.

This phenomenon appears to develop even further during the next decade, the 1980s. Those years mark a steep increase in new international R\&D partnerships from about 90 per year in the early 1980s to almost 300 made each year at the end of the 1980 s and the turn of the decade. The movement to all kinds of partnerships since the seventies and early eighties was triggered by fundamental changes in the structure of the global economy and by the ongoing process of technological change. Some examples are homogenization of markets, fierce competition, and ongoing globalization tendencies. Ever-increasing costs of R\&D and the increasing complexity of products combined with a strong increase in the speed of technological developments are the main drivers from a technological perspective (Haklisch, 1989).

The early 1990s show a decrease in the newly made international partnerships to about 170. From then onwards there is an increase in the number of newly made international R\&D partnerships leading to another peak in 1995 with a record of nearly 315 newly established international R\&D partnerships. From 1995 to 1999 , we can witness a decrease again to nearly 230 partnerships in 1999. This number is still considerably higher than the figures found for most years since the early 1980s. In 2000 , the number of partnerships is increasing again to almost 260 newly established international $R \& D$ partnerships.

In other words, there is a clear pattern of growth in the newly made international R\&D partnerships if one looks at the historical data since 1971. In the early years there was a steady growth pattern with an acceleration since the 1980s. Explanations for this overall growth pattern of newly made international R\&D partnerships are generally related to motives that lead to collaborations on R\&D by companies. The main drivers for this growth in new partnerships are related to important industrial and technological changes in the 1980s and 1990s that have led to increased complexity of scientific and technological development, higher uncertainty surrounding $R \& D$, increasing costs of $R \& D$ projects, and shortened innovation cycles that favor collaboration (see Contractor and Lorange, 1988; Dussauge and Garette, 1999; Hagedoorn, 1993, 1996; Mowery, 1988; Mytelka, 1991; Nooteboom, 1999; OECD, 1992).

In the above we indicated that previous contributions had already established that joint ventures seem to have become gradually less popular if compared to other forms of partnering. If we consider the specific trend for international R\&D partnerships during the past three decades, we arrive at a similar conclusion. Looking at the overall trend in Figure 2.2, we notice a sharp decline in the share of joint ventures in international $R \& D$ partnering from on average a $85 \%$ share in the early 1970 s to $15 \%$ in 2000 . During the mid-1970s the share of R\&D joint ventures was still at a level of about $70 \%$, whereas in the early 1980 s this share reached around $55 \%$. In the late $1980 \mathrm{~s}$, the share of joint ventures increased to nearly $65 \%$, after which the 
downward trend reached a level of $20 \%$ during the first half of the 1990 s, until it arrived at a small share of $15 \%$ at the end of the decade. These overall trends in newly established international R\&D partnerships indicate two major developments. First, companies seem to increasingly prefer contractual partnerships to joint ventures. Second, the growth in partnerships since the early 1980s is largely caused by an overwhelming increase in the absolute numbers of contractual partnerships.

Figure 2.2 The share (\%) of joint ventures in all newly established international $R \& D$ partnerships (1971-2000).

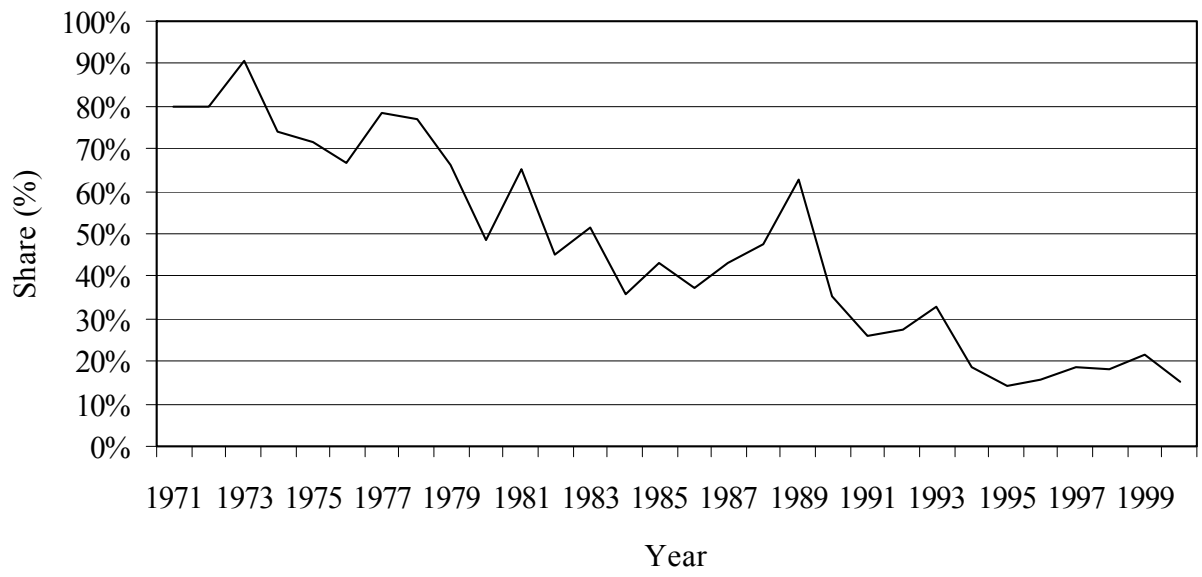

\subsection{Sectoral patterns in international R\&D partnerships}

According to the literature, inter-firm partnerships are associated with so-called hightech sectors and other sectors, where learning and flexibility are important features of the competitive landscape (Ciborra, 1991; Dussauge and Garette, 1999; Eisenhardt and Schoonhoven, 1996; Gomes-Casseres, 1996; Harrigan and Newman, 1990; Oster, 1992). The literature also reveals that many R\&D partnerships are concentrated in a limited number of, mainly R\&D intensive, industries (see for instance, Dussauge and Garette, 1999; Hagedoorn and Schakenraad, 1993; Link and Bauer, 1989; Mytelka, 1991). As this chapter concentrates on international $R \& D$ partnerships, one can expect that, given the asymmetrical distribution of $R \& D$ efforts across industries, this particular group of partnerships will also be concentrated in R\&D intensive industries.

In order to discuss the importance of sectoral differences in international $R \& D$ partnering, $R \& D$ intensity indicators will be used to differentiate between industries. High-tech sectors (with an R\&D intensity ranging from $10.0 \%$ to $15.0 \%$ ) include: pharmaceuticals including biotech, information technology, aerospace and defense, and heavy electrical equipment. Medium-tech sectors include (with an average R\&D intensity ranging from $3.0 \%$ to $5.0 \%$ ): chemicals, automotive, consumer electronics, and instrumentation and medical technology. Finally, low-tech sectors (with an R\&D 
intensity below 1\%) include: food and beverages, metals, and oil and gas (see OECD, 1997).

During the whole period, i.e. from 1971 to 2000, the average share of high-tech sectors was $68 \%$. The average share of medium-tech sectors accounted for $30 \%$. Finally, low-tech sectors had an average share of $2 \%$ during this period. From Figure 2.3 it can be seen that the above mentioned expected dominance of international $R \& D$ partnering by high-tech, i.e. R\&D intensive, industries has only gradually developed as it did not become apparent until the mid-1980s. During the 1970s R\&D partnerships in high-tech industries still counted for only between $20 \%$ and $50 \%$. During that same period, medium-tech industries had a share of between at least $50 \%$ and $80 \%$. Although the share of medium tech sectors was high, we witness a decrease over time.

Figure 2.3 The share (\%) of high-tech, medium-tech, and low-tech industries in all newly established international R\&D partnerships (1971-2000).

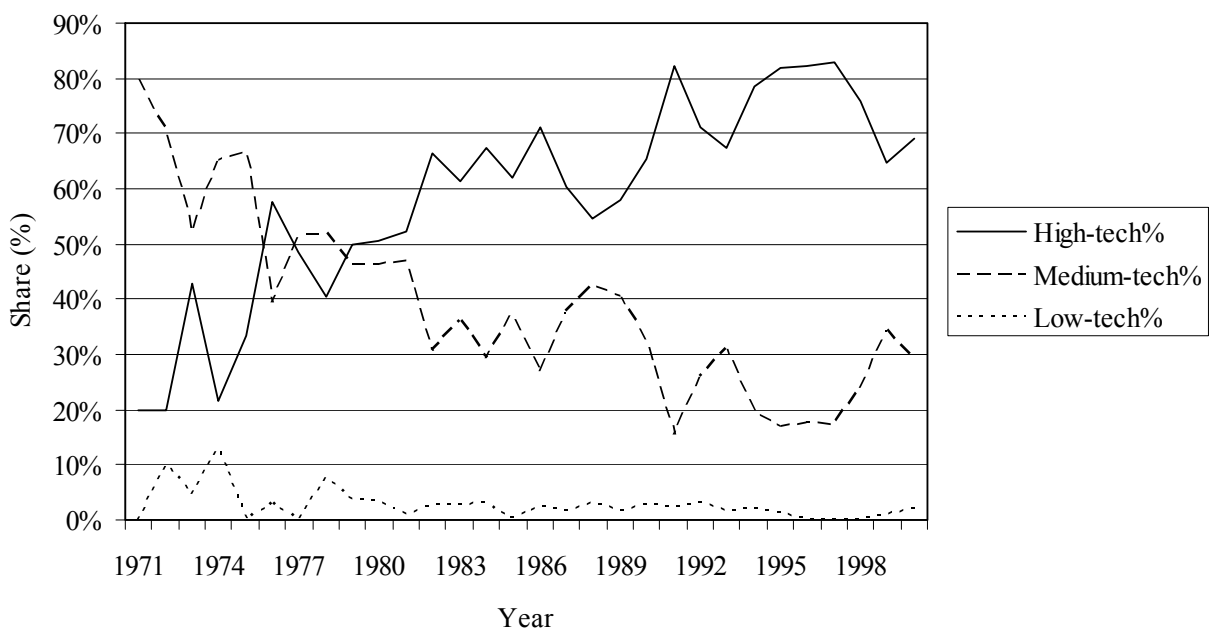

The 1980s and 1990s mark a period where the growth of R\&D intensive industries is reflected in the increasing importance of these high-tech industries in R\&D partnering. From 1980 to 1997, the share of high-tech industries in newly established international R\&D partnerships increased from about $50 \%$ to over $80 \%$, after which there has been some decline. During the same period the share of medium-tech industries in these partnerships decreased sharply from about 50\% to less than 20\% from 1980 to 1997 , after which we can witness an increase again. In 2000, the share of newly established international R\&D partnerships in the medium-tech sector is nearly $30 \%$. The share in the high-tech sector is more than twice as much, i.e. nearly $70 \%$.

As high-tech industries have become so dominant in international R\&D partnering, we also looked at the trends in the share of individual high-tech sectors (see Figure 2.4). The information technology sector (including computers and office equipment, telecom, semiconductors, industrial automation, and software) has become 
important in terms of its total R\&D effort, which is reflected in its share in international R\&D partnering. With a few exceptional years during the 1970s and the mid-1990s, the information technology sector has by far the largest share in the sectoral distribution of international R\&D partnerships. During the first half of the $1970 \mathrm{~s}$, it has an average share of about $6 \%$ of all these partnerships, rising quickly to around $20 \%$ at the end of the 1970 s. The early 1980 s mark a period in which there was a very sharp increase in the share of the information technology sector from around $20 \%$ in the early 1980 s to on average $45 \%$ during the rest of the decade. In the early $1990 \mathrm{~s}$, there is again a decrease after which the average share of the information technology industry remains on average around $35 \%$.

Figure 2.4 The share (\%) of high-tech industries in all newly established international R\&D partnerships (1971-2000).

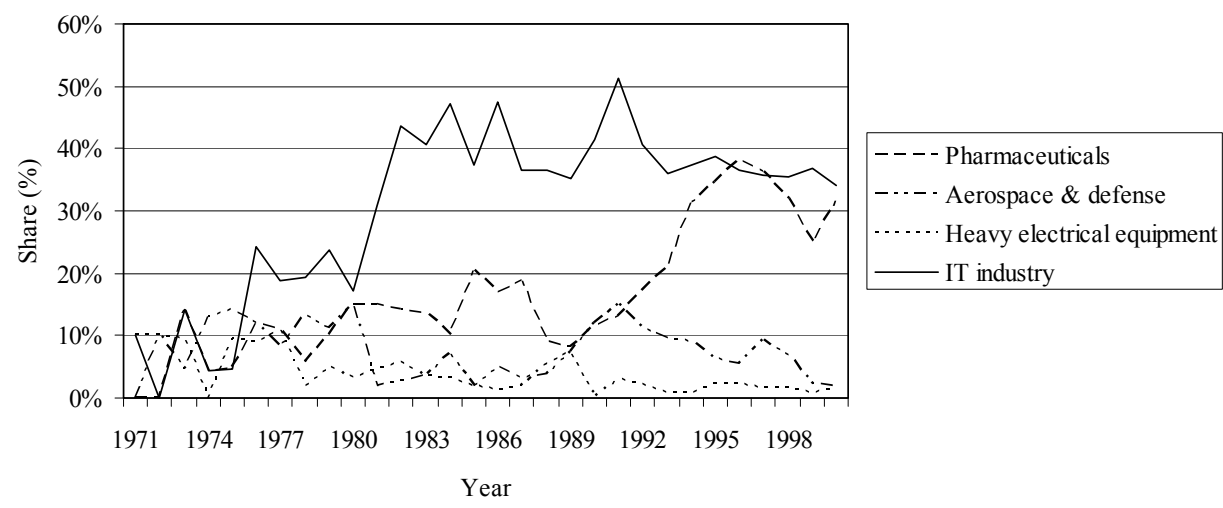

Since the early 1970s there is a gradual increase in the share of pharmaceutical international R\&D partnerships, rising from about $10 \%$ during most of the 1970 s to $15 \%$ during most of the 1980 s. After a decline to about $10 \%$ at the turn of the decade, the share of the pharmaceutical international R\&D partnerships has risen to nearly $40 \%$ in 1996, after which we can witness a decline again. In 2000, the share of the pharmaceutical industry in international R\&D partnerships is above $30 \%$, i.e. very close to the share of the information technology industry.

As the share of the information technology industry and the pharmaceutical industry have become so dominant in the international $\mathrm{R} \& \mathrm{D}$ partnering in high-tech industries, the share for the third and fourth high-tech industries, i.e. the aerospace and defense sector, and the heavy electrical equipment sector, has remained relatively small. During the 1970s the shares of the aerospace and defense industry and the heavy electrical equipment industry were around the $10 \%$ and $5 \%$, respectively. During most of the 1980s, the share of the aerospace and defense sector was around the $5 \%$ and it peaked at $15 \%$ in 1991, after which it decreased again. During the rest of the 1990 s its share decreased to only $2 \%$ in 2000 . The share of the heavy electrical 
equipment sector was also around 5\% during the 1980 s while it decreased to $2 \%$ during the 1990s.

With respect to the most important trends in medium-tech sectors, it can be said that the chemical sector dominates international R\&D partnering in medium-tech industries. There is a decreasing trend in its share, starting at 50\% in 1971 to $10 \%$ in 2000. The consumer electronics sector started quite dominant with about $30 \%$ during the early 1970 s, which decreased to $2 \%$ at the end of the decade. During the 1980 s and $1990 \mathrm{~s}$ it remained at a level of around $2 \%$. The share of the automotive industry in medium-tech sectors remains around the 5\% during the period from the 1970 s to the early 1990s. Since 1995 there has been an increase, resulting in a share of $12 \%$ in 2000. The share of the instrumentation and medical technology sector remains around $5 \%$ from 1971 to 2000 .

Finally, it will be no surprise that low-tech industries (for instance food and beverages, metals, and oil and gas) do not seem to play an important role in all of this. The share of low-tech industries fluctuates around the $6 \%$ during the first half of the 1970 s, after which their share remains at about $2 \%$.

In the above we already mentioned that contractual partnerships have become the dominant form of international inter-firm R\&D partnering which, combined with the current dominance of R\&D intensive industries, would suggest that high-tech industries are probably also the industries where contractual arrangements are more important than in the non high-tech industries. Previous literature also seems to suggest that the degree of technological change in industries might influence the preferred form of partnering by companies.

Lundan and Hagedoorn (2001) also conclude that contractual alliances dominate strategic technology partnering in so-called high-tech industries. It has to be stressed that complexity governs the choice of inter-organizational mode of governance taken by an alliance, and thereby influences the strategic implications for the companies involved. This complexity consists of organizational complexity, technological developments, and the international context of these alliances (Hagedoorn and Narula, 1996).

Contractual agreements demand less control through administration and supervision and are more suited for agreements that are less complex regarding their span of objectives. Therefore, companies appear to prefer this mode of strategic technology partnering for agreements with a one-dimensional goal, strongly biased in favor of applied research cooperation. Under condition of rapid technological change, as in the case of so-called high-tech industries, learning, organizational change and quick strategic response ask for flexible forms of organization (such as alliances), because new knowledge expires quickly and timely learning from partners appears more appropriate than control through formal and hierarchical organization as such (Eisenhardt and Schoonhoven, 1996; Hagedoorn, 1993).

Harrigan $(1985,1988)$ also indicates that rapid technological change in sectors of industry induces the formation of somewhat informal forms of partnering such as non-equity, contractual partnerships. The technological instability of industrial sectors 
is a crucial factor in explaining different patterns for joint ventures and contractual partnerships (Osborn and Baughn, 1990). Hagedoorn and Narula (1996) conclude that joint ventures are disproportionately represented in relatively mature, i.e. relatively stable, industries. Stable sectoral environments favor joint venturing as the main form of inter-firm partnering, whereas unstable sectoral environments lead to a preference for contractual agreements. In general, contractual agreements are particularly preferred in high-tech industries, whereas joint ventures still play some role in other sectors (Yu and Tang, 1992). We think that a similar pattern can be expected for joint ventures and contractual alliances in international $R \& D$ partnering.

In order to measure the sectoral differences in contractual partnerships, we will follow Hagedoorn (2002) by applying a "relative contractual partnering index" per sector, which expresses the degree to which contractual international R\&D partnerships are more important in some sectors than in others. ${ }^{2}$ This index can be calculated by setting the ratio of contractual international partnerships versus international joint ventures for each sector against the overall contractual-joint ventures ratio of international partnerships. If one considers the relative contractual partnering indexes for high-tech, medium-tech and low-tech industries during the period 1971-2000, one finds that this index for high-tech industries is 1.63, the index for medium-tech industries is 0.43 and for low-tech industries it is 0.35 . These figures do indicate that international R\&D partnering in high-tech industries is of a disproportionate contractual nature. A more detailed overview of these relative contractual partnering indexes during the three decades of this analysis, including the period as a whole, at the level of industries can be found in Figure 2.5 and Table 2.1.

Figure 2.5 indicates that international R\&D partnering in the pharmaceutical industry (including pharmaceuticals in the biotechnology) is over two and one-half times as much concentrated in contractual $R \& D$ partnerships than the average for all industries. The aerospace and defense sector and the information technology sector have about respectively 1.7 and 1.5 times as many contractual partnerships as the industry-wide average. Because of the dominance of these high-tech industries, the medium and low-tech sectors are (with the exception of the most R\&D intensive medium-tech sector, the instrumentation and medical technology industry) below the industry-wide average.

Further information on trends in these relative contractual partnering indexes can be found in Table 2.1. In pharmaceuticals and the information technology industry, there exists an above-average preference for contractual international R\&D partnering throughout most of the past decades, whereas the aerospace and defense industry shows a rapid decline in importance of contractual international R\&D

\footnotetext{
${ }^{2}$ This relative contractual partnering index (RCI) is calculated per sectors as the relative distribution of the number of sectoral contractual partnerships $\left(\mathrm{CP}_{i}\right)$ and sectoral joint ventures $\left(\mathrm{JV}_{i}\right)$ set against the distribution of all contractual partnerships (TCP) and all joint ventures (TJV) (Hagedoorn, 2002).
}

$R C I_{i}=\frac{C P_{i} / J V_{i}}{T C P / T J V}$ 
partnering, in particular during the most recent decade. In heavy electrical equipment, a rather less R\&D intensive sector within high-tech industries, and the non-high-tech sectors chemicals, and food and beverages, joint ventures have had a disproportionate importance throughout most of the past decade. In instruments and medical technology, a rather R\&D intensive sector within medium-tech industries, international joint ventures have gradually become less important as contractual international R\&D partnering has become the dominant mode of partnering. In the automotive industry and consumer electronics, there appears to be two opposite developments: in the automotive industry it seems that contractual R\&D partnering is becoming less important, whereas the opposite seems to hold for consumer electronics.

Figure 2.5 Relative contractual partnering indexes, per sector (1971-2000).

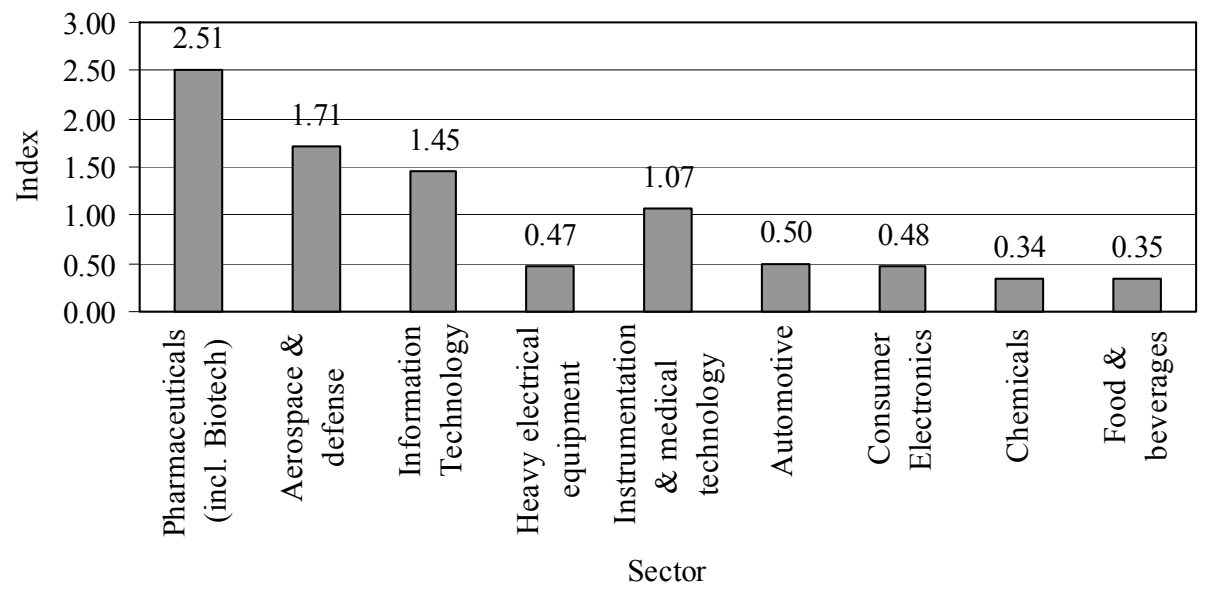

Table 2.1 Relative contractual partnering indexes of all sectors (1971-2000).

\begin{tabular}{llccc}
\hline Sectors (general) & Sectors (specific) & $1971-1980$ & $1981-1990$ & $1991-2000$ \\
\hline High-tech & Pharmaceuticals (incl. Biotech) & 4.47 & 2.96 & 1.48 \\
High-tech & Aerospace \& defense & 9.55 & 3.28 & 0.72 \\
High-tech & IT industry & 0.61 & 1.45 & 1.51 \\
High-tech & Heavy electrical equipment & 0.34 & 0.67 & 0.61 \\
Medium-tech & Instrumentation \& medical technology & 0.52 & 0.97 & 1.25 \\
Medium-tech & Automotive & 2.20 & 0.38 & 0.51 \\
Medium-tech & Consumer electronics & 0.90 & 0.32 & 1.62 \\
Medium-tech & Chemicals & 0.25 & 0.42 & 0.38 \\
Low-tech & Food \& beverages & 0.69 & 0.37 & 0.40 \\
\hline
\end{tabular}




\subsection{Patterns in international $R \& D$ partnerships of companies from different economic regions}

To take a closer look at international differences in R\&D partnering, we will differentiate between partnerships and companies from different economic regions and trading blocks. The first group of countries that we distinguish consists of the OECD countries, i.e. the Triad (North America, Western-Europe, and Japan), and Australia, New Zealand, Turkey, and South Korea. Partnerships and companies from the socalled newly industrialized countries (NIC) include Taiwan, Singapore, Malaysia, Hong Kong, some Latin American countries (Brazil, Argentina, and Mexico) and Israel. Partnerships and companies from the so-called less developed countries (LDC) include Latin American countries (with the exception of those mentioned in the above), Asian countries (with the exception of those mentioned in the above) and Africa. Finally, partnerships and companies from East European previously state-run economies and former communist countries (FCC) refer to Bulgaria, Croatia, Czech Republic (including former Czechoslovakia), Hungary, Kazakhstan, Poland, People's Republic of China, Russian Federation (including the former Soviet Union), Slovakia, Ukraine, Vietnam, and (former) Yugoslavia.

When analyzing trends and patterns in international $R \& D$ partnerships, we will use the following division: intra-OECD partnerships include all partnerships between companies from the OECD. Next, OECD-NIC partnerships, OECD-LDC partnerships, and OECD-FCC partnerships refer to partnerships in which at least one of the partners is from the OECD, whereas also at least one of the other partners is from an NIC, LDC, or FCC country respectively. Finally, non-OECD partnerships include all partnerships in which none of the partnering companies is from the OECD.

Looking at the overall pattern in international $R \& D$ partnering during the period under study, i.e. 1971-2000 (see Figure 2.6), it becomes clear that companies from the OECD participate in over $99 \%$ of these newly established international R\&D partnerships. More than $90 \%$ of the international $R \& D$ partnerships are made between companies from the OECD. Additional material also indicates that there is a more or less gradual decline in the share of joint ventures in intra-OECD R\&D partnerships, from $80 \%$ in 1971 to nearly $15 \%$ in 2000 . The share of joint ventures in the total of OECD-NIC, OECD-LDC, and OECD-FCC international R\&D partnerships starts at $100 \%$ in the 1970 s and this also decreases to nearly $15 \%$ in 2000 . The share of joint ventures in non-OECD international R\&D partnerships remains rather high throughout the period 1971-2000. The share of joint ventures is around $65 \%$ during the $1970 \mathrm{~s}$, while it decreases to around 50\% during the 1990s.

These findings are consistent with previous literature. Freeman and Hagedoorn (1994) have analyzed the extent to which diverging international patterns in distribution of technological capabilities are also found in inter-firm technology cooperation. They report that over $95 \%$ of research relationships have been established within the Triad, suggesting a straightforward relationship between the degree of technological sophistication of an industry and the degree of participation of firms 
from less developed countries. Not surprisingly, the higher the R\&D intensity of the industry, the lower the participation of companies from developing and emerging economies, as such firms are seldom in possession of knowledge-intensive resources that would be attractive to a Triad-partner.

Figure 2.6 Distribution of newly established international R\&D partnerships, economic regions (1971-2000).

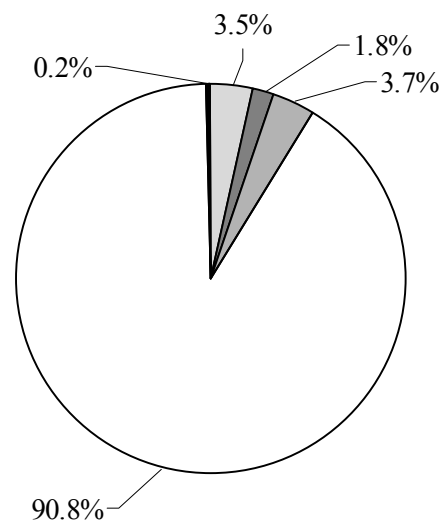

\begin{tabular}{|l|}
\hline OECD-NIC \\
$\square$ OECD-LDC \\
$\square$ OECD-FCC \\
$\square$ INTRA_OECD \\
$\square$ NON-OECD \\
\hline
\end{tabular}

Freeman and Hagedoorn (1994) also conclude that in high-tech industries the share of the intra-Triad research relationships established during the 1980s has remained high. Whereas the growth of inter-firm research partnerships with partners from outside the Triad was primarily found in partnerships with companies from Asian countries, such as South Korea, Taiwan, Singapore, and Hong Kong. Furthermore, one of their major conclusions is that inter-firm partnering had not led to a catching up of the LDC countries and most of the NIC countries, as it is much more part of a process of concentration of technological competencies within the developed economies (Freeman and Hagedoorn, 1994; Hagedoorn, 1996). Our study indicates the same. The share of NIC countries increased from $2.6 \%$ in the 1970 s to $4.3 \%$ in the $1990 \mathrm{~s}$, while the share of FCC countries increased from $0.8 \%$ to $3.5 \%$ respectively. However the share of LDC decreased from $2.4 \%$ in the 1970 s to $1.4 \%$ in the $1990 \mathrm{~s}$. So, overall (taking NIC, LDC, and FCC as one group), there is only a net increase from $5.8 \%$ in the 1970 s to $9.2 \%$ in the 1990 s.

Additionally, Duysters and Hagedoorn (2000) conclude that technological complementarity between partners turns out to be the major driving force behind the growth of international strategic technology partnerships. The most advanced NIC countries have increasingly become aware of the importance of building up technological competencies in knowledge-intensive sectors. Technological know-how from companies in the developed economies is crucial to establishing a prominent (technological) position in high-tech markets. NIC companies are gradually becoming 
interesting partners for companies from the developed economies, due to their technology-intensive assets, particularly in electronics and related industries. Therefore it is not surprising that compared with other international partnerships, Triad-NIC partnerships are increasingly found in high-tech sectors. The use of contractual agreements, dominating intra-Triad alliance formation since the eighties, has also become widespread practice for Triad-NIC partnerships in the nineties. This could indicate that these partnerships have reached a general level of sophistication that is coming close to that of many domestic partnerships and international R\&D partnerships between major trading partners. If one considers these major changes, then it is clear that several NIC countries have developed from "junior" partners in the early seventies to important players in the 1990s (Duysters and Hagedoorn, 2000).

Because of the dominant role played by companies from the OECD, it is interesting to take a closer look at the role that the different international economic and trading blocks play in all of this in general, and within the OECD in particular. In the following, we will differentiate between partnerships and companies from North America (USA and Canada), Europe (EU and EFTA countries), Asia (with Japan as most dominant player), and all other countries (including countries from Central and South America, Australia and Pacific, Middle East, and Africa).

Figure 2.7a Distribution of newly established international R\&D partnerships, economic regions (1971-2000).

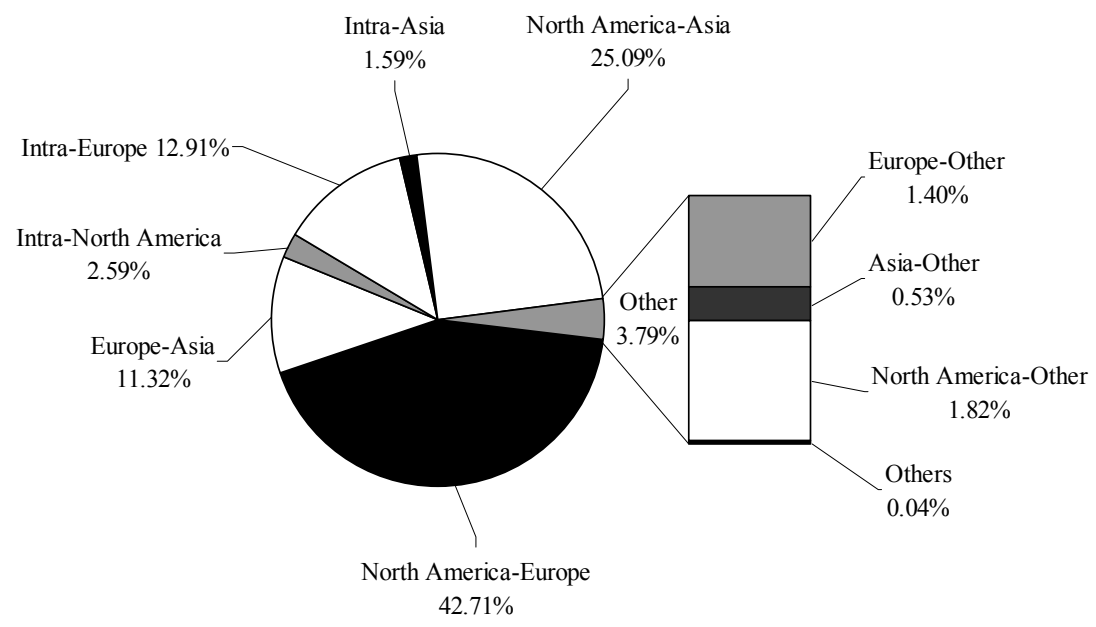


Figure 2.7b Distribution of newly established international R\&D partnerships, economic regions (1971-1980).

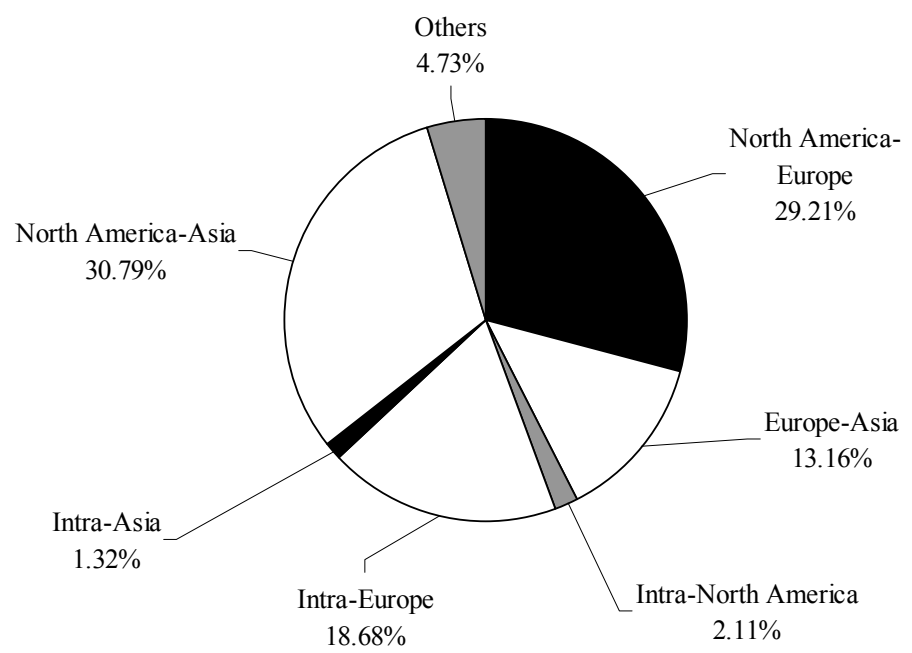

Figure 2.7c Distribution of newly established international R\&D partnerships, economic regions (1981-1990).

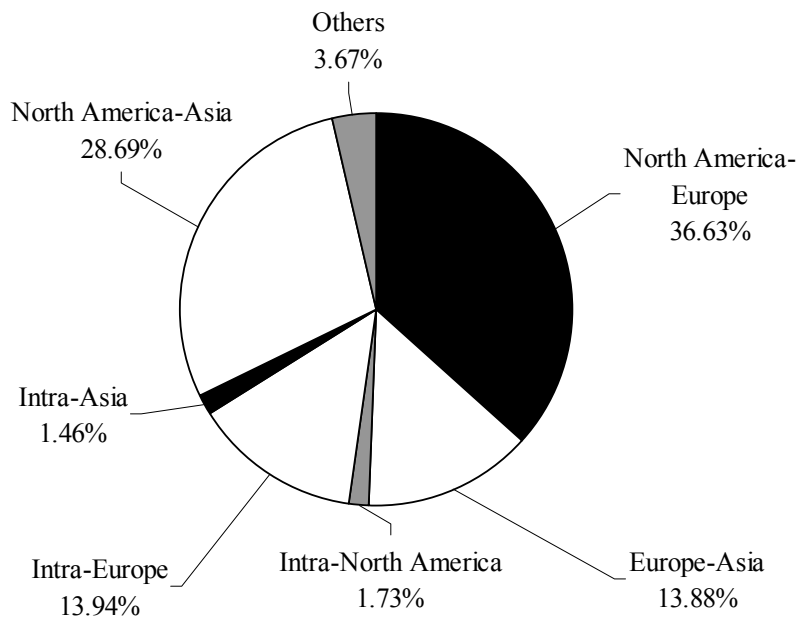


Figure 2.7d Distribution of newly established international $R \& D$ partnerships, economic regions (1991-2000).

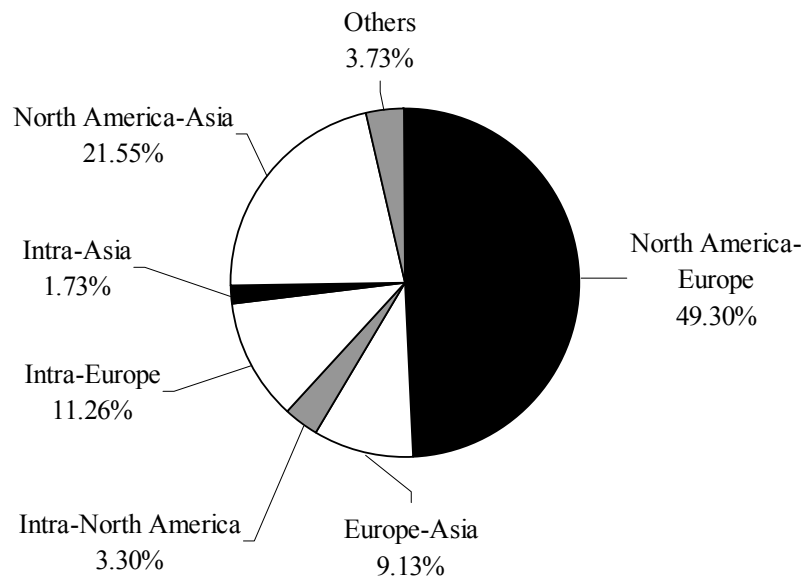

Looking at Figure 2.7a-d, some striking changes in the overall distribution of international R\&D partnerships since the 1970s are revealed. First of all, it becomes clear that international R\&D partnerships between North America and Europe play a very dominant role. Starting with a share of around $30 \%$ in the 1970 s, the share of North American-European international R\&D partnerships has increased with $20 \%$ to around $50 \%$ in the $1990 \mathrm{~s}$. Second, the share of North American-Asian international R\&D partnerships has gradually decreased from more than $30 \%$ in the 1970 s to less than $22 \%$ in the $1990 \mathrm{~s}$. Third, intra-European international R\&D partnering has gradually decreased from almost $19 \%$ in the 1970 s to about $11 \%$ in the 1990 s.

When taking a closer look at the distribution of these international R\&D partnerships for individual countries, it becomes clear that the USA plays a very dominant role in all of this. Almost $75 \%$ of all newly established international R\&D partnerships has at least one North American country as a partner, from which more than $70 \%$ are US companies (Plasschaert and Van den Bulcke, 1992). Japan comes second with almost $28 \%$ of all international R\&D partnerships having at least one Japanese company. For Europe as a whole, in more than $86 \%$ of all international R\&D partnerships, at least one of the partners is from a European country. The leading countries in Europe are the UK and Germany (both around 18\%), France (13\%), and the Netherlands (11\%).

Additional statistics, not presented in this chapter, reveal that the dominance of the USA has gradually increased from a share in international R\&D partnerships of around $60 \%$ in the 1970 s to around $65 \%$ and $75 \%$ in the next two decades. Interestingly, the development in the share of Japanese companies follows an opposite 
direction; it has decreased from more than $40 \%$ in the first decade of this study to respectively less than $35 \%$ and around $20 \%$ in the following two decades. Finally, Germany's share has witnessed an increase from $13 \%$ in the first decade to over $20 \%$ in 1990-2000. Most other countries have undergone relatively small changes.

Finally, an important remark has to be made with respect to the small share of intra-North American newly established international R\&D partnerships. In this study, intra-American international $R \& D$ partnerships only include partnerships between the USA and Canada. When including domestic intra-North American partnerships, of which between $90-95 \%$ stands for US companies, the picture looks very different (Hagedoorn, 2002). According to Hagedoorn (2002), North America clearly dominates the world of R\&D partnering. The important role of intra-North American partnerships, including international as well as domestic partnerships, is only a relatively recent development. During the 1960s and 1970s the share of intra-North American partnerships was less than $20 \%$ of all (international as well as domestic) R\&D partnerships, during the 1980 s their share was less than $24 \%$, though during the 1990s their share was over 41\% (Hagedoorn, 2002).

Concluding, it can be said that companies from the OECD participate in over $99 \%$ of all newly established international R\&D partnerships, from which $90 \%$ are intra-OECD. Within the OECD, Europe (86\%) and North America (75\%) are the most dominant regions, with the US (70\%) as most dominant country. The share of the NIC and FCC countries has only increased marginally, while the share of the LDC countries even shows a decreasing trend. Overall, some NIC companies are gradually becoming interesting partners for OECD companies, although their total share in newly established international R\&D partnerships is still relatively small.

\subsection{Conclusions}

Despite an overall increase in international R\&D partnerships, their importance has become relatively more concentrated within major economic regions instead of becoming overwhelmingly global (see also Duysters and Hagedoorn, 1996). International R\&D partnerships are dominated by companies from the world's most developed economies (OECD). Companies from OECD countries participate in nearly $99 \%$ of all the international R\&D partnerships and more than $90 \%$ of these partnerships are within the OECD. US companies particularly play a dominant role in international $\mathrm{R} \& \mathrm{D}$ partnering. More than $70 \%$ of all partnerships have been established with at least one US company, whereas more than $65 \%$ of these partnerships are made between at least one US company and the OECD. This picture does parallel the current worldwide distribution of R\&D resources and capabilities (Freeman and Hagedoorn, 1994). The dominance of the USA also reflects its leading role in $\mathrm{R} \& \mathrm{D}$ and production in major high-tech industries such as the information technology industry and pharmaceutical biotechnology (OECD, 1992). 
The overall growth in international R\&D partnerships during the past decades is largely due to the growth in the number of contractual agreements. The dominant position of joint ventures in inter-firm R\&D agreements is now almost completely taken over by contractual agreements as about $85 \%$ of the recently established international partnerships are of a contractual nature. In general, the demand for flexibility has increased in many industries, where inter-firm competition is affected by increased technological development, innovation races, and the constant need to generate new products. Contractual international $R \& D$ partnerships enable companies to increase their strategic flexibility through short-term joint $R \& D$ projects with a variety of partners.

The role of technological development is also apparent in the sectoral background of international R\&D partnering. Over the last three decades, there has been a gradual increase in the share of high-tech industries in international R\&D partnering. During the late 1990 s, nearly $70 \%$ of the newly established international R\&D partnerships can be found in the information technology and the pharmaceutical industries. Furthermore, there is an over-representation of contractual partnerships in these sectors, which again stresses the role of flexibility in inter-firm R\&D partnering. Contractual international R\&D partnerships are major drivers of inter-firm networks that have become apparent in many high-tech industries. 


\section{CHAPTER $3^{3}$}

\section{INTELLECTUAL PROPERTY RIGHTS AND THE GOVERNANCE OF INTERNATIONAL R\&D PARTNERSHIPS}

\subsection{Introduction}

This chapter studies the effect of different regimes of intellectual property rights protection on the preference of companies for particular forms of international interfirm R\&D partnerships. It particularly looks at the choice for either equity based international $R \& D$ joint ventures or contractual international R\&D partnerships. In that context we will pay attention to a number of specific issues that refer to the international differences in intellectual property rights protection and the role that technological change might play in all of this. ${ }^{4}$

This contribution builds on a small number of previous studies, such as Pisano (1989) and Oxley (1999). Pisano's (1989) study was mainly considering intellectual property rights protection and the preference for particular forms of inter-firm partnerships in the US biotechnology industry. His study suggests that companies prefer equity-based partnerships to contractual agreements when they are confronted with higher levels of specific knowledge transfer, when uncertainty surrounding partnerships increases, and when small-number bargaining conditions create risk. Oxley's (1999) seminal study on a somewhat similar set of questions, presented an analysis of the choice between equity and contractual partnerships from the perspective of US companies within a limited number of high-tech sectors. Her study indicates that in international partnerships established during the 1980s, both the nature of the actual transactions within a partnership and the 'quality' of the institutional environment for intellectual property rights protection affect the preference for equity or contractual partnerships. When US companies were partnering with companies from countries with weaker intellectual property rights protection standards, they preferred to enter into an equity-based partnership rather than to engage in a contractual agreement.

Following directions for further study mentioned in Oxley (1999), we will analyze intellectual property rights protection and the preference of companies for particular forms of international partnerships for a wider range of industries and for companies from a large number of countries. We study over two thousand

\footnotetext{
${ }^{3}$ This chapter is based on Hagedoorn J., Cloodt, D. and H. van Kranenburg, 2005, Intellectual property rights and the governance of international R\&D partnerships, Journal of International Business Studies, 36:2, pp. 175186. Furthermore, the chapter was selected for inclusion in the Best Paper Proceedings of the Academy of Management Conference, which was held in New Orleans, Louisiana, USA, from 6 until 11 August 2004.

${ }^{4}$ This chapter deals with the environmental embeddedness of inter-firm partnering. International differences in intellectual property rights protection play a role at the macro level of environmental embeddedness while technological change plays a role at the meso level of environmental embeddedness.
} 
international partnerships set up by nearly two thousand companies from fifty-three countries. Our analysis will concentrate on a specific group of inter-firm partnerships, i.e. international $R \& D$ partnerships, because in these joint $R \& D$ activities the protection of intellectual property rights is more crucial than in other forms of partnering such as standard customer-supplier relationships, second-sourcing or joint marketing agreements (Dussauge and Garette, 1999; Osborn and Baughn, 1990; Teece, 1986).

Our research focuses on the period from the mid-nineteen seventies to the end of the nineteen nineties when intellectual property rights protection, in particular patent-related property rights protection, appear to still diverge substantially between many countries at different levels of economic and technological development. Also, during that period many companies were still building up experience in international R\&D partnering with companies from countries from a less developed intellectual property rights regime. As such, each of these new partnerships can be seen as a crucial strategic decision. In that sense, our contribution can highlight a number of important aspects of the international strategic behavior of companies and their choices with regard to the form of international inter-firm partnering in the context of intellectual property rights protection.

In the following section, we will develop a small set of hypotheses and some basic theoretical understanding of relevant phenomena. The next section discusses our sample, data collection and the variables that we will analyze. After the presentation of the results, we will discuss these results separately and draw some major conclusions with an outline of future research.

\subsection{Theory and hypotheses}

In terms of organizational and legal features, the various inter-firm partnerships that share R\&D activities fall into two basic forms of governance: equity-based joint ventures and contractual R\&D partnerships (Hagedoorn, 2002). Joint ventures are separate organizational units created and controlled by two or more parent companies. Within the spectrum of 'hybrids' in between markets and hierarchies, joint ventures represent a relatively high level of hierarchical control as parent companies share formal control over the joint venture through equity sharing (Harrigan, 1985; Williamson, 1996). In general, the ownership structure of joint ventures is determined by equity participation through the ex ante allocation of ownership shares to the parent companies. This generates a governance structure where the sponsoring companies can monitor the activities of the joint venture as they are represented on the board of directors. This equity sharing is also expected to align the motivation of the partners, creating mutual interests, which reduces the possibilities for opportunistic behavior by partners (Oxley, 1997; Pisano, 1989). R\&D joint ventures are examples of these semiautonomous, operating ventures that perform $R \& D$ and a number of other functions, 
usually extending their other activities into production, marketing and various services (Dussauge and Garrette, 1999; Hagedoorn, 2002).

Contractual R\&D partnerships, such as joint R\&D pacts and joint development agreements, cover common R\&D activities of two or more companies on a project or program basis. Such undertakings imply the temporary sharing of some R\&D resources in $\mathrm{R} \& \mathrm{D}$ projects or $\mathrm{R} \& \mathrm{D}$ programs for which companies agree on the shared input of human resources, technologies, laboratories and equipment. Compared to $R \& D$ joint ventures, contractual $R \& D$ partnerships are, due to their intended temporary nature and their lack of equity sharing and organizational control, characterized by a lower level of hierarchical control (Hagedoorn, 2002; Oxley, 1999).

Given the fact that it is by definition impossible to contractually specify all concrete results of joint R\&D in advance, while there is also no administrative and organizational control based on equity, these contractual $R \& D$ partnerships are to be seen as clear examples of incomplete contracts. More specifically, the incomplete nature of these contractual R\&D arrangements is the result of two types of ex ante information deficiency that are affected by the uncertainty surrounding R\&D. First, it is often extremely difficult, if not impossible, to anticipate the exact nature and the extent of future knowledge as well as to assess the potential of further application of this future knowledge, that is generated through cooperative $\mathrm{R} \& \mathrm{D}$ projects. The speed of technological development and the constant changes in R\&D activities in many $\mathrm{R} \& \mathrm{D}$ intensive sectors of industry add to the uncertainty regarding the assessment of the value of future knowledge (Freeman and Soete, 1997). Second, there is usually some degree of asymmetry in the knowledge capabilities of these partners because the sharing of identical capabilities would only generate some economies of scale but no economies of scope. This asymmetry in the context of the sharing and developing of information based on proprietary and tacit knowledge also implies that companies do not have a precise ex ante understanding of the value of the joint knowledge base of the partners to the extent that it can be written into a contract (Chi and Roehl, 1997).

\subsubsection{The preference for equity joint ventures or contractual partnerships}

The literature on the choice that companies make with regard to the governance structure of joint activities, such as equity joint ventures and contractual partnerships, focuses on three main topics: the monitoring of the actual collaboration, the enforcement of contractual terms, and the adequate specification of property rights (Oxley, 1999; Pisano, 1989; Williamson, 1996). Our understanding of the difficulties that companies might face with monitoring joint activities and enforcing contractual terms related to property rights suggest that the more relevant these difficulties are, the higher the likelihood that companies will prefer a more hierarchical mode of shared governance that increases their actual control, i.e. control through a joint venture. Moreover, if inter-firm partnerships involve the exchange of technology, which is by definition the case when companies jointly undertake $R \& D$, there is a chance of 
involuntary knowledge and technology leakage indicating serious appropriability hazards (Oxley, 1997; Teece, 1986). Ceteris paribus, the higher the appropriability hazards in inter-firm partnering, the more companies will prefer the joint venture mode.

These particular aspects of decision making with regard to the mode of governance for inter-firm collaboration seem highly relevant for understanding international R\&D partnerships. As discussed in the above, joint R\&D is by definition an uncertain activity for which it is very difficult, if not impossible, to define ex ante both the complete results and their implications for future activities. Costs can be estimated for the short term but the larger the R\&D program and the longer its time horizon, the more difficult it will be to give an accurate estimate. Monitoring of R\&D activities is possible but, in case of international R\&D partnering, the international nature of collaboration only adds to the uncertain nature of the activity. In international R\&D cooperation the appropriability hazards could, due to a lack of familiarity with circumstances in other countries, be even larger than in domestic inter-firm $R \& D$ partnering. Also, the enforcement of contractual terms for international R\&D partnering largely depends on the specific legal system that regulates such partnerships. It is well known, that there are large international differences in contract law, while the actual enforcement of such laws is even non-existent in many countries (Ginarte and Park, 1997; Varsakelis, 2001). Most relevant in the current context are the international differences in intellectual property rights protection. In general, the literature suggests that the more economically developed countries are, the more they have established a legal system that enforces contract law and the stronger their intellectual property rights protection (Marron and Steel, 2000; Varsakelis, 2001).

The above suggests a number of important questions with respect to the preference of companies for international $R \& D$ joint ventures or international contractual R\&D partnerships in the context of:

- $\quad$ international differences in intellectual property rights protection,

- $\quad$ the role of technological change in their competitive environment.

In the following sections, these questions regarding some specifics of the governance of R\&D partnering will be discussed further in a differentiated international and sectoral setting. Given the emphasis on the role of intellectual property rights protection and the appropriability hazard of knowledge leakage to partners, the hypotheses are formulated from the perspective of the company (partner) with its headquarters in the country with the higher level of intellectual property rights protection.

\subsubsection{The effect of international differences in intellectual property rights protection}

Countries show considerable differences with regard to important aspects of intellectual property rights protection, such as the efficiency with which property 
rights can be established by those seeking legal protection. Other major differences refer to the broadness of the interpretation of property rights and the actual enforcement of property rights protection by the authorities. These international differences in intellectual property rights protection are most clearly demonstrated for patents. Ginarte and Park (1997) analyze these international differences in terms of five major categories of patent rights protection:

- $\quad$ the extent of coverage, i.e. the patentability of inventions in major patent classes

- $\quad$ the participation of a country in international agreements

- $\quad$ the provisions for loss of protection

- $\quad$ the legal enforcement mechanisms

- $\quad$ the duration of protection for a patent.

In general, the more economically developed a country, the higher it scores on these dimensions of intellectual property rights protection (Ginarte and Park, 1997; Marron and Steel, 2000; Primo Braga, Fink and Paz Sepulveda, 2000; Rapp and Rozek, 1990; Varsakelis, 2001). The level of intellectual property rights protection in a country is also an important predictor for its attraction of foreign direct investment (Dunning, 1993; Ferrantino, 1993; Lee and Mansfield, 1996; Mille, 1997; Saggi, 2000; Seyoum, 1996; Smarzynska, 2002) and international trade (Ferrantino, 1993; Fink and Primo Braga, 1999).

The effective protection of intellectual property rights through patent laws and related measures reduces the risk for companies when they engage in various international activities that demand foreign direct investment, extensive and long-term trading relationships or international inter-firm partnering. Essentially, any international transaction with a company from a country with a well-established intellectual property rights regime is less likely to be subject to substantial appropriation hazards than transactions with companies from countries that offer little or no protection (Lee and Mansfield, 1996). Given the moral hazard in joint R\&D, where, as discussed in the above, there is always the risk of unanticipated knowledge leakage, intellectual property rights protection in international R\&D partnerships can be expected to be even more relevant than in most other international transactions and investments. Therefore, the strength of intellectual property rights protection in particular countries is expected to be an important institutional and environmental factor in the choices that companies make when they engage in international R\&D partnerships (Muralidharan and Phatak, 1999). ${ }^{5}$

Companies from a domestic environment characterized by substantial intellectual property rights protection are confronted with higher appropriability hazards and potentially subsequent costs when they engage in contractual agreements with companies from countries with relatively poorer conditions of intellectual property rights protection. Equity joint ventures are expected to be reserved for

\footnotetext{
${ }^{5}$ As suggested by one of the reviewers of the Journal of International Business Studies, taxation, subsidies, governmental protection and other institutional factors might also have some effect on the organizational and contractual choices that companies make.
} 
circumstances with such greater appropriability hazards because they offer managerial and organizational control and increase the possibilities for adequate monitoring and oversight (Oxley, 1999; Teece, 1986). This implies that companies from countries with relatively well-developed systems of intellectual property rights protection will, due to increased appropriability hazards, prefer to rather form equity-based R\&D partnerships than contractual R\&D partnerships with companies from countries with less developed systems of intellectual property rights protection. Hence,

Hypothesis 1: The preference of a company for hierarchical control in an international $R \& D$ partnership is inversely related to the level of intellectual property rights protection in the home country of its partner.

\subsubsection{The effect of sectoral technological change}

Contributions by Ciborra (1991), Eisenhardt and Schoonhoven (1996), GomesCasseres (1996), Hagedoorn and Duysters (2002), Harrigan and Newman (1990) and Oster (1992) suggest that in general inter-firm partnerships are associated with sectors of industry where learning and flexibility are important features of the competitive landscape. Under these conditions, companies learn from a variety of partners in a flexible setting of temporary partnerships. Dussauge and Garetti (1999), Hagedoorn (2002), Link and Bauer (1989) and Mytelka (1991) indicate that many of these partnerships are concentrated in a limited number of, mainly $R \& D$ intensive, industries.

A related body of literature suggests that the level of technological change in industries might influence the preferred form of governance for partnering by companies. According to Harrigan $(1985,1988)$ rapid technological change in industries induces the formation of somewhat informal forms of partnering such as non-equity, contractual partnerships. Osborn and Baughn (1990) suggest that the technological instability of industrial sectors is a crucial factor in explaining different patterns for joint ventures and contractual partnerships. Yu and Tang (1992) emphasize that stable sectoral environments favor joint venturing as the main form of inter-firm partnering, whereas unstable sectoral environments lead to a preference for contractual arrangements. Auster (1987) and Hagedoorn and Narula (1996) found that companies involved in international partnerships preferred contractual agreements to equity based partnerships as the technology involved became more sophisticated.

Although these contributions differ with respect to their theoretical backgrounds, major research questions and the actual indicators used in research, a general picture emerges from this literature. Contractual agreements are particularly preferred in high-tech industries, i.e. sectors with high levels of technological change, whereas joint ventures play a role of disproportionate importance in other industries. We expect similar patterns for joint ventures and contractual alliances in international $R \& D$ partnering. This implies that the form of governance for international $R \& D$ 
partnering, as chosen by companies, is probably also affected by the level of technological change in the industry in which their international R\&D partnering takes place. Thus,

Hypothesis 2: The preference of a company for hierarchical control in an international $R \& D$ partnership is inversely related to the level of technological change in the sector of industry in which an international $R \& D$ partnership is established.

\subsection{Research methods}

\subsubsection{Sample and data collection}

We will analyze a sample of 2005 international R\&D partnerships, taken from the MERIT-CATI database (see Appendix A). These 2005 partnerships are sponsored by 1956 companies from 53 countries. 35\% of these international R\&D partnerships are joint ventures and $65 \%$ are contractual $R \& D$ partnerships. Our research covers the period 1975-1999. The international R\&D partnerships formed between the pairs of companies in this sample are unique and first combinations, adding to the crucial nature of their choice for a particular governance structure for an R\&D partnership.

\subsubsection{Dependent variable}

Our hypotheses associate the differences in the regime of intellectual property rights protection in the home countries of partnering companies and the sectoral level of technological change with the governance structure of $R \& D$ partnerships, i.e. the preference for an equity R\&D joint venture or a contractual R\&D partnership. The dependent variable represents the choice of the governance structure for each $R \& D$ partnership from the perspective of the partner from the country with the highest level of intellectual property rights protection. This dependent variable, $R \& D$ partnership, is coded 1 if the partnership is organized as an equity joint venture and 0 if the partnership is organized as a contractual partnership.

\subsubsection{Independent variables}

The ratio that measures the difference in intellectual property rights protection in the home countries of partnering companies, international IPR ratio, indicates the basic international dissimilarities in intellectual property rights protection (hypothesis 1). The measure of country differences in the intellectual property rights protection index is based on the information found in Ginarte and Park (1997) and additional data provided by Walter Park. As already explained in the above, their index refers to a 
number of major categories for patent rights protection. Previous research indicates that the level of patent protection appears a good indication of the more general level of intellectual property rights protection (Marron and Steel, 2000; Ostergard, 2000). Ginarte and Park (1997) provide an index of patent rights protection with five years intervals for a large number of countries.

For our analysis, the relevant indexes refer to the years 1975, 1980, 1985, 1990, and 1995. We will relate each R\&D partnership and the countries of the sponsoring companies to the first year of the interval given for these patent rights protection indexes. For instance, all partnerships found in the year 1977 refer to the patent rights protection indexes for the earlier year 1975. It turned out that taking the later year for which patent rights protection indexes are available, in this case 1980, does not have a significant effect on the measurement of this variable. In the actual statistical analysis we will apply ratios for the indexes of patent rights protection to measure the difference in the intellectual property rights protection of the home countries of both partners. Given the positive values of ratios, where differentials indicate the degree to which the intellectual property rights protection in the home country of the partner are weaker, the actual measurement of this ratio was transferred to a negative value in order to interpret the findings in the context of the expected inverse relationship mentioned in hypothesis 1 .

The variable for sectoral technological change (hypothesis 2) measures the average R\&D intensity of sectors of industry during the 1980s and 1990s as given in various OECD publications. This R\&D intensity indicates the degree to which companies in industries devote resources to $R \& D$ that generate a continuous flow of newly developed technologies, new products and new processes, representing differences in the degree of sectoral technological change (Freeman and Soete, 1997; OECD, 1992). R\&D intensities measure the R\&D expenditures as a percentage of output, ranging for instance from 22.7 for aerospace and defense to 0.8 in food and beverages (OECD, 1992). We recoded the OECD classification of industries to the industry categories found in the MERIT-CATI database.

\subsubsection{Control variables}

Consistent with prior research on international partnerships, we included a number of control variables for the specific characteristics of the two companies in each international R\&D partnership and for some general characteristics of the countries from which partners originate. The literature indicates that the size of companies and their size differences might play a role in the partnership formation process of companies (Berg, Duncan and Friedman, 1982; Hagedoorn and Duysters, 2002; Hagedoorn and Schakenraad, 1994; Harrigan, 1988; Mytelka, 1991; Oxley, 1997). However, the empirical findings from these studies appear to be somewhat inconclusive. The variable size ratio indicates the actual difference in size between the partnering companies. Size of each company is measured in million US dollar sales for 
the year the partnership was established. Information on the size of companies was accessed through well-known databases such as Amadeus, Compustat, Disclosure, Securities Data, and Worldscope.

The experience of companies with setting up partnerships is known to positively affect their partnering behavior (see for instance Barkema, Shenkar, Vermeulen and Bell, 1997; Dyer and Singh, 1998; Gulati, 1995; Ring and Van de Ven, 1992). The variable average experience measures the average of a simple count of previous partnerships for the two companies in the R\&D partnership (Oxley, 1999). The variable ratio of total experience indicates the degree to which companies in a partnership differ in their actual experience with setting up inter-firm R\&D partnerships. It is calculated as the count of the previous partnerships made by the company from the country with the highest level of intellectual property rights protection divided by the count of the previous partnership made by its partner. Both control variables for experience count the number of all relevant R\&D partnerships of both companies, found in the MERIT-CATI database, established since 1970 but prior to the specific international R\&D partnership formed between the two companies.

The formation of R\&D partnerships can also be influenced by the difference in innovative capabilities of companies, where larger differences indicate that the 'leading' company would prefer to form an equity partnership to have more control in order to reduce appropriability hazards (Oxley, 1999; Teece, 1986). The ratio of patenting expresses the degree to which companies have similar or dissimilar strengths in innovative capabilities. The actual measurement is the number of patents that companies have obtained during a five years period prior to their R\&D partnership, while controlling for size differences. Data on patents are taken from the US Patent and Trademark Office database (US Department of Commerce). Although this US data could imply a bias in favor of US companies and against non-US firms, the patent literature suggests several reasons to choose US patent data (see e.g. Patel \& Pavitt, 1991). Frequently mentioned are the importance of the US market, the genuine patent protection offered by US authorities, and the level of technological sophistication of the US market which makes it almost compulsory for non-US companies to file patents in the US (see also Appendix B).

We included two, more or less, standard control variables from the international business literature that characterize differences between the countries from which companies in an international R\&D partnership originate. For cultural distance we have used the well known Kogut and Singh (1988) index of cultural differences between countries, based on Hofstede (1980). The ratio of the openness of the economy refers to the ratio between two countries in their share of total trade (exports plus imports) to real GDP per capita (Summers and Heston, 1991). For each of these country-based variables we expect that larger ratios might positively affect the choice for equity $R \& D$ partnerships because these dissimilarities imply a certain degree of unfamiliarity for first time collaborators. Finally, we include a trend variable, time, to account for a possible growth in the total number of R\&D partnerships over time and a gradual change in the distribution of equity $R \& D$ partnerships and contractual 
partnerships (Hagedoorn and Van Kranenburg, 2003). This trend variable was calculated by assigning a value to each specific year, corresponding with the 'distance' to the first year of the period under investigation, i.e. 1975.

\subsection{Results}

Table 3.1 presents the descriptive statistics and the correlation matrix for the variables in this study. Table 3.2 provides the results of a stepwise logit analysis. Given the unambiguous nature of the results for the various models, we will only discuss the results for the full model (model 4). Compared to the other models, this full model has the expected highest log likelihood value. Turning to the hypotheses testing, it is clear that the results demonstrate strong support for the hypotheses. Consistent with hypothesis 1 , the results indicate that the preference of companies for hierarchical control, through a joint venture mode for international R\&D partnering, is inversely related to the strength of intellectual property rights protection in the home country of their partner. We also predicted that the level of technological change in an industry would have an inverse effect on the preference of companies for hierarchical control in international R\&D partnerships (hypothesis 2). Our results do indicate there is a significant, negative effect, which suggests that establishing international R\&D partnerships in industries characterized by higher levels of technological change decreases the likelihood that these partnerships take the form of equity joint ventures.

As for the effects of the control variables, it turns out that the variables for the size ratio, both experience variables and the ratio of the openness of the economy, have an insignificant impact on the choice for equity or contractual R\&D partnerships. Apparently, size differentials do not affect the particular choice that companies have to make for the form of an R\&D partnership. We also found no effect of the experience that companies have with setting up partnerships on the structure of their international partnership. The variables indicating the degree to which companies differ with regard to the openness of the economy in their home country and the cultural distance between partners also do not seem to impact their choice for a particular form of international R\&D partnering.

The other control variables do have a significant effect on the preference for a particular form of governance of international R\&D partnerships. We found a positive, significant effect for the degree to which companies have dissimilar strengths in innovative capabilities, indicating that with increasing differentials in these capabilities companies appear to prefer R\&D joint ventures. Also, the negative time trend shows that there is a clear general tendency to gradually change to a preference for contractual R\&D partnerships. 


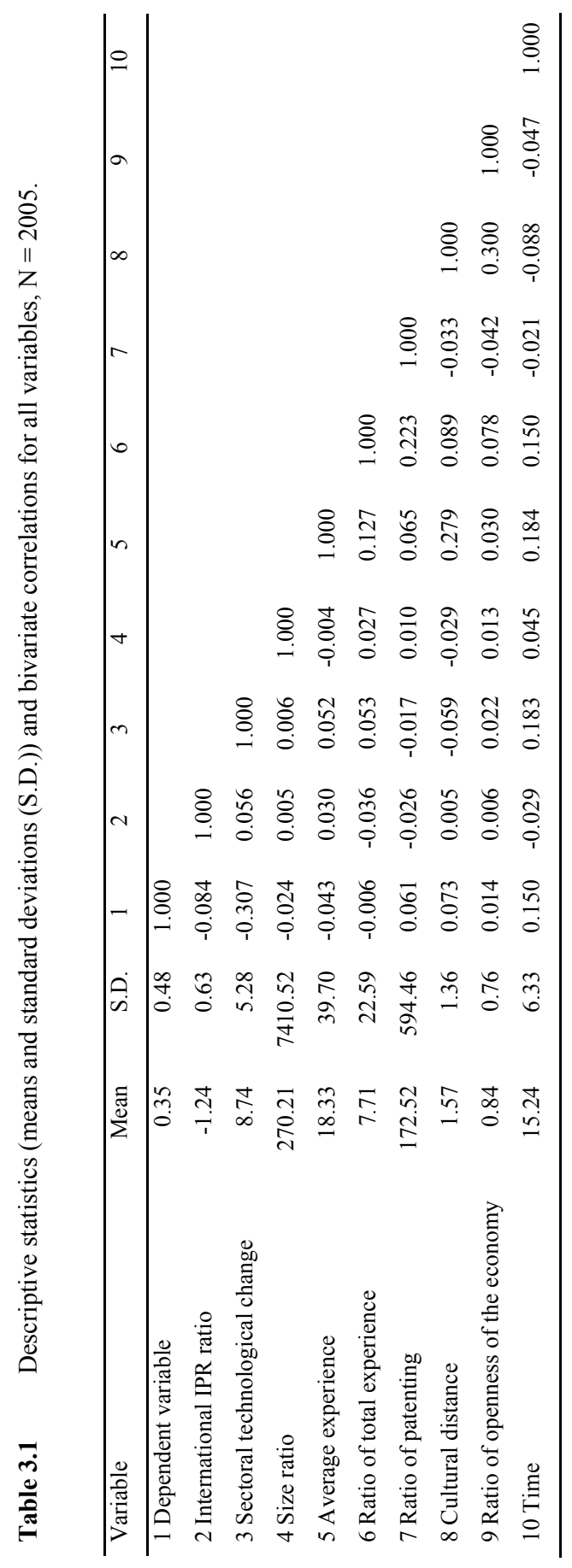


Table 3.2 Estimation results of the binomial logit analysis.

\begin{tabular}{|c|c|c|c|c|}
\hline Variable & Model 1 & Model 2 & Model 3 & Model 4 \\
\hline \multirow[t]{2}{*}{ Constant } & $1.1011^{* * *}$ & -0.0073 & $1.7088^{* * *}$ & $0.8690^{* * *}$ \\
\hline & $(0.1417)$ & $(0.2939)$ & $(0.1617)$ & $(0.3184)$ \\
\hline \multirow[t]{2}{*}{ International IPR ratio } & & $-0.9502^{* * *}$ & & $-0.7046^{* * *}$ \\
\hline & & $(0.2225)$ & & $(0.2323)$ \\
\hline \multirow[t]{2}{*}{ Sectoral technological change } & & & $-0.0999^{* * *}$ & $-0.0970^{* * *}$ \\
\hline & & & $(0.0090)$ & $(0.0091)$ \\
\hline \multirow[t]{2}{*}{ Size ratio } & -0.0003 & -0.0003 & -0.0003 & -0.0002 \\
\hline & $(0.0005)$ & $(0.0004)$ & $(0.0004)$ & $(0.0004)$ \\
\hline \multirow[t]{2}{*}{ Average experience } & -0.0007 & -0.0004 & 0.0001 & 0.0005 \\
\hline & $(0.0011)$ & $(0.0012)$ & $(0.0013)$ & $(0.0015)$ \\
\hline \multirow[t]{2}{*}{ Ratio of total experience } & 0.0045 & -0.0035 & $0.0052^{*}$ & 0.0046 \\
\hline & $(0.0028)$ & $(0.0029)$ & $(0.0030)$ & $(0.0030)$ \\
\hline \multirow[t]{2}{*}{ Ratio of patenting } & $0.0002^{* *}$ & $0.0001^{*}$ & $0.0002^{* *}$ & $0.0002^{*}$ \\
\hline & $(0.0001)$ & $(0.0001)$ & $(0.0001)$ & $(0.0001)$ \\
\hline \multirow[t]{2}{*}{ Cultural distance } & $0.0840^{* *}$ & $0.0895^{* *}$ & 0.0544 & 0.0616 \\
\hline & $(0.0366)$ & $(0.0375)$ & $(0.0395)$ & $(0.0404)$ \\
\hline \multirow[t]{2}{*}{ Ratio of openness of the economy } & -0.0403 & -0.0333 & -0.0122 & -0.0115 \\
\hline & $(0.0616)$ & $(0.0622)$ & $(0.0658)$ & $(0.0666)$ \\
\hline \multirow[t]{2}{*}{ Time } & $-0.1235^{* * *}$ & $-0.1270^{* * *}$ & $-0.1078^{* * *}$ & $-0.1111^{* * *}$ \\
\hline & $(0.0092)$ & $(0.0093)$ & $(0.0097)$ & $(0.0099)$ \\
\hline $\mathrm{N}$ & 2005 & 2005 & 2005 & 2005 \\
\hline Log likelihood & -1308.948 & -1293.150 & -1183.111 & -1173.955 \\
\hline
\end{tabular}

In addition to the variables applied in the above, we used a set of complementary variables such as various measures for political risk in home-countries of partners and the patenting intensity of the home-countries of partners. These variables were highly correlated with the intellectual property rights protection in countries and, consequently, they were dropped from the analysis (see also Oxley, 1999 and Sampson, 2004). We also analyzed the role of nominal differences for ratio-based variables and we applied log-transformed measures of these nominal differences in order to control for very large dissimilarities between partners. Both exercises lead to similar results. 


\subsection{Discussion}

The above demonstrates that intellectual property rights protection is an important aspect in the decision-making regarding international inter-firm $R \& D$ partnering. Admittedly, intellectual property rights protection refers to a wider group of intellectual properties than just patents. However, the international differences in the efficiency of patent protection, the broadness of patent protection and the actual enforcement of patent laws (Ginarte and Park, 1997) do indicate a general intellectual property rights protection climate in a country (Marron and Steel, 2000; Ostergard, 2000). Apparently, companies do realize that in that context international R\&D partnerships can create serious appropriability hazards unless the necessary precautions are taken (Oxley, 1997; Teece, 1986). International R\&D partnerships appear to carry all the flags that caution companies, in particular if they are dealing with first-time encounters with foreign partners. These precautions can be made by creating equity-based control in setting up separate organizational entities, i.e. joint ventures, which allow for continuous monitoring of the joint $R \& D$ activities. This monitoring is possible because usually each sponsor is, based on its equityparticipation, represented in the management of the joint venture. An important finding of this chapter is that international differences or similarities in intellectual property rights protection seem to affect the preference for contractual or equity-based inter-firm R\&D partnerships.

The emphasis in this chapter on R\&D partnerships highlights an important aspect of the appropriability hazards of shared activities, i.e. the possible leakage of knowledge. R\&D partnerships are, given the complementary nature of most partnerships, characterized by information asymmetry that increases the potential risk of knowledge leakage (Chi and Roehl, 1997; Hagedoorn, 2002). International differences in intellectual property rights protection seem to also indicate major differences in country levels of technological capabilities (Ginarte and Park, 1997; Primo Barga et al, 2000; Rapp and Rozek, 1990). This implies that apart from the fundamentally intrinsic uncertainty of $\mathrm{R} \& \mathrm{D}$, international cooperation without adequate safeguards to counter involuntary knowledge transfer, would further increase the uncertainty that already surrounds the outcome of joint $R \& D$. Joint ventures provide better protection and monitoring than incomplete contracting through R\&D pacts and joint development agreements. Support for this particular aspect of our understanding of the preference for particular forms of governance is also found in the positive effect of differences in innovative capabilities in pairs of companies on their preference for equity-based international $\mathrm{R} \& \mathrm{D}$ partnerships.

Important aspects of the above confirm some findings in previous research by Oxley (1997) and Sampson (2004). However, our contribution also demonstrates that the relationship between international intellectual property rights protection and the preference for particular forms of governance of inter-firm partnering is of a general nature. Our research shows that this relationship is not only relevant for understanding the behavior of US companies and their choices with regards to organizing their 
international $\mathrm{R} \& \mathrm{D}$ partnerships. It also extends to companies from a large variety of other countries that are confronted with asymmetries in intellectual property rights protection. Our findings also demonstrate that these insights are not only relevant for a small number of high-tech industries but that they appear appropriate across-the-board of a wider range of industries. Furthermore, although a large number of countries partially closed the gap in intellectual property rights protection regimes in the context of Trade Related Aspects of Intellectual Property Rights (TRIPS) of the Uruguay Round of the GATT negotiations, major differences in intellectual property rights protection are still in effect. In that context, our results indicate that the relationship between international intellectual property rights protection and the preference for particular forms of governance of inter-firm partnering is still valid at the end of the 1990s.

The level of technological change in sectors of industry also affects the preference of companies for particular modes of governance for international R\&D partnering. The more industries are characterized by intensive R\&D and technological changes that create a constant flow of new products and new processes, the more flexibility and organizational change appear to be relevant for companies in those industries (Harrigan, 1988; Oster, 1992). In particular contractual R\&D partnerships, play a major role in attempts made by companies to answer the need for organizational flexibility as they are constantly adjusting to frequent technological changes while monitoring new technologies and introducing crucial innovations themselves (Dussauge and Garetti, 1999; Gomes-Casseres, 1996; Oster, 1992). This does not only apply to domestic partnerships, sectoral technological changes also affect the preference for particular modes of governance of international R\&D partnerships. The findings of this chapter confirm previous studies that suggest that joint ventures are preferred in stable environments with relatively little technological change, whereas flexible, short-term contractual partnerships are preferred in dynamic environments characterized by higher levels of technological change (Hagedoorn, 2002; Osborn and Baughn, 1990).

Although not a central topic in our research, the results for some variables are relevant for understanding some important questions regarding the bearing of transaction or firm-level characteristics on the type of partnership. Findings by Oxley (1997) indicate that firm-level attributes such as size (differences), experience with setting up partnerships, innovativeness of companies, and the industry in which a partnership operates, would have no effect on the form of inter-firm partnerships. Our research does indeed indicate similar findings for size differentials between partners and their experience with inter-firm partnering. However, differences in the innovativeness of partnering companies and their sectoral technological settings clearly play a role in our analysis. This indicates that in the context of international R\&D partnering, firm-level characteristics crucial to the specific aim of this group of partnerships, i.e. the sharing and joint undertaking of $R \& D$, are important aspects to be considered when contemplating the mode of governance for R\&D partnerships. The larger the differential between the innovative capabilities of partners, the more the 
'leading' company will search for protection of these capabilities by means of equity joint ventures.

The finding that, contrary to some other studies, the experience with previous partnerships does not have a significant effect on the governance of international $R \& D$ partnerships can largely be explained by the specific historical situation with regard to $R \& D$ partnering. The number of $R \& D$ partnerships did not really grow until the latter part of the period under investigation, which implies that most companies were only able to build up substantial experience towards the end of the period. In addition to this, it appears that companies might realize that experience as such can help them assess a new situation but a new $R \& D$ partnership with a company from a less developed IPR regime warrants a careful consideration of control issues in international R\&D partnerships.

\subsection{Conclusions}

International differences in intellectual property rights protection are a significant factor for companies to consider when engaging in international $R \& D$ partnerships. When companies find themselves in an environment with less secure intellectual property rights protection, they rather choose for equity-based $R \& D$ joint ventures than for contractual partnerships. The level of technological change in industries has an inverse effect on the preference for international $R \& D$ joint ventures. International contractual R\&D agreements, characterized by organizational flexibility, are preferred in $R \& D$ intensive and innovative industries.

Although this chapter does reveal some very important aspects of intellectual property rights protection and international $R \& D$ partnering, it still has certain limitations that indicate an agenda for future research. First of all, there is still a clear need for further studies based on larger samples than the one used in this chapter. The current sample is already larger, referring to a longer and more recent period, and also more differentiated in terms of industries and countries than the samples in other studies. Nevertheless, future studies could focus on a larger variety of forms of interfirm partnering, an even larger group of countries and a more des-aggregated sample of industries. Second, other forms of intellectual property rights protection than patent protection, such as copyrights and software protection, seem to have become important since the early 1990s. A combination of a study of recent developments in other forms of intellectual property rights protection with recent trends and patterns in inter-firm partnering could generate additional insight into the management of external knowledge transfer in an international context. Third, a better understanding of the actual transfer of knowledge in international partnerships could benefit from research using a wider range of detailed firm-level indicators, a better comprehension of sectoral characteristics and more sophisticated country-level measures than those currently available. 



\section{CHAPTER 4}

\section{MULTI-CAUSAL RELATIONSHIPS BETWEEN R\&D PARTNERSHIP FORMATION, POSITIONAL EMBEDDEDNESS AND INNOVATIVE PERFORMANCE}

\subsection{Introduction}

Knowledge is a central issue in research traditions that stress the importance of organizational learning and the transfer and diffusion of knowledge and innovative capabilities within a company and between companies (Grant, 1996). Organizational learning is based on the idea that a company's stock of knowledge evolves from its past achievements, and, in turn forms the foundation for a novel set of knowledge (Pennings and Harianto, 1992). The opportunities for organizational learning increase when a firm is exposed to new and diverse ideas, and thereby to new knowledge. New knowledge is said to be generated by the exchange and recombination of knowledge.

Making proper use of this new knowledge is found to be a relevant contribution to a firm's innovative performance (Cohen and Levinthal, 1989; Nonaka and Takeuchi, 1995; Pakes and Griliches, 1984). In this way, innovative performance can be defined as the output of a firm's underlying knowledge base (Griliches, 1984) and a firm's underlying dynamic capabilities by which firms alter their existing knowledge base (Eisenhardt and Martin, 2000).

New knowledge can be generated within the firm (internally) or outside the firm (externally). External knowledge generation is based on differences in technological capabilities between firms. By making use of inter-firm collaborations, such as R\&D partnerships, firms can learn from these differences, generate new ideas and practices, generate new knowledge and create incentives for innovative behavior (Ahuja, 2000a, Cohen and Levinthal, 1989, 1990). In other words, alliances can be seen as mechanisms to access or transfer new technological knowledge and to facilitate innovative efforts (Ahuja, 2000a; Baum, Calabrese and Silverman, 2000; Mody, 1993; Teece, 1992).

External knowledge generation by means of alliances has become more and more important during the last decades. This is related to important industrial and technological changes that have led to increased complexity, higher uncertainty surrounding R\&D, increasing costs of $R \& D$ projects, and shortened innovation cycles that favor collaboration (see Contractor and Lorange, 1988; Dussauge and Garette, 1999; Hagedoorn, 1993, 1996; Mowery, 1988; Mytelka, 1991; Nooteboom, 1999; OECD, 1992).

However, not only the number of one-on-one alliances has become greater but firms are also increasingly embedded in networks of alliances (De Man, 2004). An important issue in that respect is the central position that a firm occupies within the 
alliance network since that determines its access to information and thereby to external knowledge. It is said that firms that occupy a central position within the alliance network are exposed to knowledge from a greater number of partner firms as well as from a greater variety of firms, and by this are more likely to increase their innovative activities (Powell et al., 1996). ${ }^{6}$ So, besides engaging into one-on-one alliances, occupying positional embeddedness within the network is expected to have a positive effect on the innovative performance of companies as well.

Within the strategic management literature, a large amount of research has studied the relationships between alliances, positional embeddedness and innovation. One of the important gaps in our understanding about these relationships results from the fact that most of these studies focus on singular causal relationships (Grodal, 2004). Examples of some singular causal studies mentioned by Grodal (2004) are the impact of alliances on innovation (Ahuja, 2000a; Baum, Calabrese and Silverman, 2000; Kraatz, 1998; Shan, Walker and Kogut, 1994; Stuart, 2000; Walker, Kogut and Shan, 1997), the impact of positional embeddedness on innovation (Powell, Koput, Smith-Doerr and Owen-Smith, 1999), and the impact of innovation on alliances (Ahuja, 2000b; Stuart, 1998).

When studying this literature, we observe that the various relationships between alliance formation, positional embeddedness and innovation have been treated only in pairs thus far (thereby ignoring other relationships). Furthermore, the different studies investigating these various relationships all make use of a specific dataset. These datasets differ from each other, thereby making it difficult to get an overview of how the various relationships relate and complement each other.

In order to be able to "link" the different studies with each other and to be able to draw some conclusions from this body of studies as a whole, there is a need to investigate the relationships using one and the same dataset. Such a joint consideration of the three factors and their interaction, may also provide us with more insight in the validity of the arguments made by previous authors such as for instance Ahuja (2000a, 2000b) and Powell et al. (1996, 1999). Powell et al. (1996, 1999) have found positive effects of positional embeddedness on a company's innovative performance. Ahuja has found positive effects of alliance formation on innovation (2000a) as well as positive effects of innovative performance on the formation of new alliances (2000b). The findings from previous literature all ignore one important issue, namely how do alliance formation, positional embeddedness and innovation relate and can they possibly complement one another?

The main goal of this chapter is to develop an integral understanding of the relationships between alliances, positional embeddedness and innovative performance. Apart from a theoretical contribution, this research project specifically aims to make an empirical contribution. The available empirical studies on this matter typically examine the relationship between two factors and do not incorporate the third one, let alone how they interact.

\footnotetext{
${ }^{6}$ For a background in social network theory, see Knoke and Burt (1983) and Wasserman and Faust (1994).
} 
Following some recent suggestions for a more multiple causal approach (Grodal, 2004), this chapter will attempt to contribute to the above mentioned body of literature by analyzing the multi-causal relationships and the resulting feedback loops between positional embeddedness, alliance formation and innovative performance of companies using one and the same dataset. The empirical setting of this chapter is a large international population of more than three thousand R\&D partnerships taken from the MERIT-CATI database (see Appendix A), established in four high-tech industries, during the period 1990-2000. This chapter includes more diverse sectors of industry in the analysis compared to previous literature, including the pharmaceutical (including biotech), computers, semiconductors and telecom industry. Eisenhardt and Martin (2000) and Grant (1996) explain that particularly in rapidly changing environments, such as these high-tech industries, organizational learning and technological diversification are very important for effective innovative performance and the creation of a sustainable competitive advantage. In an environment in which technological innovation and the need for technological breadth is essential, companies will be more likely to form $R \& D$ alliances in order to acquire new innovation capabilities. As demonstrated in a number of studies, high-tech industries are a major area of industrial activity where companies forge an increasing number of partnerships (Chung, Singh and Lee, 2000; Gomes-Casseres, 1996; Hagedoorn, 2002). It is also in these industries, where a large number of companies are engaged in joint R\&D through a variety of different modes of R\&D partnerships (Hagedoorn 1993; Soh, 2003). Therefore, this chapter will concentrate on R\&D partnerships within hightech industries.

Figure 4.1 The multiple causal relationships between R\&D partnership formation, positional embeddedness and innovative performance.

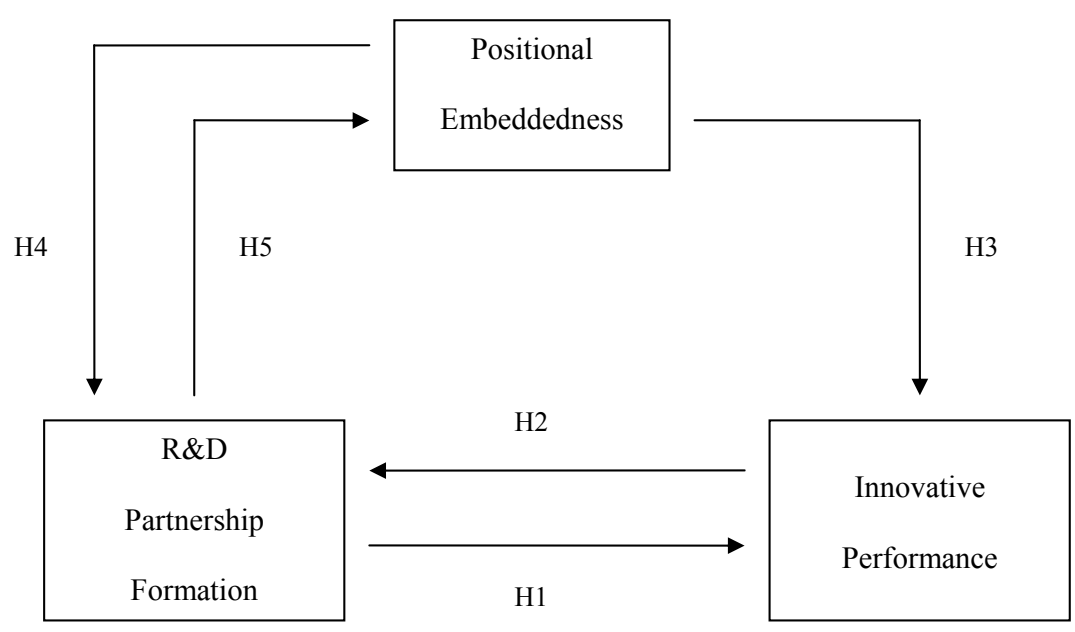


In the next section, we will first discuss the current literature on alliance formation, positional embeddedness and innovative performance. The theoretical considerations and the corresponding hypotheses that we develop will focus on the expected effect that positional embeddedness, alliance formation, and a company's innovative activities might have on each other (singular relationships). This is followed by a discussion of the possible benefits of using multiple (instead of single) causal relationships between the above mentioned factors (see Figure 4.1). The section on the research methods provides some details on the population, data sources, the independent and dependent variables, as well as the control variables used in the empirical analysis. This is followed by a presentation of the results, which are discussed further in the last section.

\subsection{R\&D partnership formation and innovative performance}

\subsubsection{The effect of $R \& D$ partnership formation on innovation}

The effect of R\&D partnership formation on innovation is clearly embedded within the dynamic capabilities view of the firm and organizational learning theory. First, the dynamic capabilities view of the firm complements the resource-based view of the firm by presenting the dynamic aspect of the resources. It takes into account the factors surrounding resources, such as how resources are developed, how they are integrated within the firm, and how they are released. Dynamic capabilities reflect a firm's ability to integrate, build and reconfigure internal and external competencies to address rapidly changing environments. The focus is on the drivers behind creation, evolution and competitive advantage (Teece et al., 1997). Dynamic resources help a firm to adjust its resource bundle and thereby to maintain the sustainability of its competitive advantage, which otherwise might be quickly eroded. The emphasis is not on a firm's current bundle of resources, but rather on the development and renewal of resources that alters the bundle of resources that a firm controls. Sometimes companies internally possess the right resources where a sustainable competitive advantage can be built upon. But often firms need to adapt resources to the environment or gain access to new resources to leverage the existing ones. If a company can not internally develop critical knowledge or can not buy it in the market, an alliance is a good option to get access to resources and skills (assets and capabilities). Alliances can provide the benefit of resource sharing, allowing firms to (re)combine knowledge, skills and physical assets (know-how), as well as the benefit of getting access to knowledge spillovers (information) (Ahuja, 2000a).

Second, organizational learning is an important motive for the creation and use of alliances and closely connected to the resource based view of the firm and the dynamic capabilities view of the firm. R\&D partnerships can be seen as a learning instrument through the exchange and imitation of resources that are embedded in the partner's organization (Kogut, 1988). In the literature, it is often mentioned that 
companies experiment with and learn from their contacts (see for instance Hagedoorn and Duysters, 2002). This learning opportunity allows firms to develop new capabilities that can be deployed throughout the organization, thereby extending its knowledge acquisition and innovative capabilities.

In a dynamic, technologically sophisticated, economic environment, learning through a variety of new contacts pays off, as this behavior can outperform short-term maximizing behavior that only concentrates on the efficiency of information transfer in existing contacts (Allen, 1988). Cooperation between companies in a dynamic environment with changing conditions encourages continuous learning by companies by helping them to learn different ways of doing things. Furthermore, it generates new ideas and new practices creating incentives for innovative behavior that further enhances their technological capabilities (Ahuja, 2000a; Barkema and Vermeulen, 1998; Cohen and Levinthal, 1989, 1990; McEvily and Zaheer, 1999).

Ahuja (2000a) explains that collaboration can affect a company's innovative performance in a positive way by providing several benefits. The first benefit is knowledge sharing. When companies engage into a R\&D partnership with each other to develop a technology, the resultant knowledge is available to all the partners. So, R\&D partnerships generate synergy effects. Second, by engaging into R\&D partnerships, companies are able to bring together complementary skills which are necessary in the innovation process. By working together, companies can enjoy these economies of specialization without making any prior investments required for internal development. Furthermore, R\&D partnerships enable companies to learn about the developed competencies of other companies which can enhance their own knowledge base and innovative performance. A third benefit deals with economies of scale. In case when larger research projects generate significantly more knowledge than smaller ones, or when there exist increasing returns so that the investment leads to a more than proportionate return in terms of innovation output, companies can take advantage of these economies of scale by engaging into R\&D partnerships.

Previous literature has analyzed the consequences of the use of $R \& D$ partnerships on companies' innovative performance (Belderbos, Carree, Lokshin, 2004; Hagedoorn and Duysters, 2002; Hagedoorn and Schakenraad, 1994; Mowery et al., 1996). Several studies have been performed within different industries, which include, among others, biotechnology (Baum, Calabrese and Silverman, 2000, Powell et al., 1999; Shan, Walker and Kogut, 1994; Walker, Kogut and Shan, 1997), telecommunications (Godoe, 2000), semiconductors (Stuart, 2000), and chemicals (Ahuja, 2000a). All the above mentioned empirical studies find strong evidence of a positive effect of partnership formation on innovativeness. The diversity of research contexts may provide support for the generalizability of the findings of these studies (see also Grodal, 2004). Following the arguments mentioned in the above, the following hypothesis can be formulated:

Hypothesis 1: The higher the number of new R\&D partnerships a company forms, the higher the likelihood that it has a higher innovative performance. 


\subsubsection{The effect of innovation on $R \& D$ partnership formation}

As mentioned in the above, a wide range of studies has analyzed the effect of partnership formation on innovative performance within different industries using a variety of research contexts. However, there are just a few studies that have examined the opposite relationship, i.e. the impact of a company's innovations on its partnership formation. For example, Ahuja (2000b) concludes that a company's innovativeness has a significant positive impact on its partnership formation in the chemicals industry. Stuart (1998, 1999) and Podolny, Stuart and Hannan (1996) report similar findings on factors that influence R\&D partnerships in the semiconductor industry. Their studies show for instance that the number of technology alliances that were formed by a company was higher among the more innovative companies.

In general, companies that are innovative are expected to have a sound knowledge base and are expected to be capable of altering their existing knowledge base by acquiring and recombining knowledge in order to generate a new knowledge base. By working together with these kind of companies, a firm enhances its ability to increase and renew its own knowledge base and dynamic capabilities, thereby improving its own innovative performance. This makes innovative companies very attractive partners to engage with in new R\&D partnerships. Hence:

Hypothesis 2: The higher a company's innovative performance, the higher the likelihood that it forms new R\&D partnerships.

\subsection{Positional embeddedness}

The literature mentioned above has been extended by linking a company's innovative performance not only to the frequency of its past alliances but also to the embeddedness of a company within its alliance network. Embeddedness refers to the structure of a network of social relations that can affect the economic actions, outcomes and behavior of a firm within the network, including its partners to whom it is (in)directly connected (Granovetter, 1992; Gulati, 1998), i.e. a company's position and embeddedness in networks of relationships (Zaheer and Zaheer, 1997).

The type of network in which a company is embedded defines the opportunities potentially available, while its position in that network structure and the types of interfirm ties it maintains define its access to those opportunities (Uzzi, 1996). These networks are valuable conduits of information providing companies with both opportunities (for instance, competitive advantage, information and knowledge exchange, higher profitability, and higher innovativeness) as well as constraints (for instance, a firm can be locked into undesirable strategic situations) and having important behavioral and performance implications for their alliances (Gulati, 1998; Gulati, Nohria and Zaheer, 2000). According to Baum, Calabrese and Silverman (2000), those configurations that provide access to more diverse information and 
capabilities per alliance, and thus produce desired benefits with minimum redundancy costs, conflicts, and complexity, will prove most beneficial for companies.

Several important research streams have emerged to define the literature of inter-actor embeddedness. The most dominant stream focuses on positional embeddedness, i.e. the position (i.e. centrality within the network) occupied by an actor in the network. Emphasis is on how position affects both actions and opportunities of an organizational actor (Burt, 1992; Uzzi, 1996, 1997), as well as its performance (Dacin, Ventresca and Beal, 1999).

\subsubsection{The effect of positional embeddedness on innovation}

Positional embeddedness refers to the position occupied by a firm in the network. The more connected a firm is with other contacts in the network (through direct ties with its alliance partners) and the more connected a firm's contacts are (through indirect ties with its partners' partners), the more central the position is that the firm occupies in the network, i.e. the higher the firm's positional embeddedness.

Companies that are more centrally located relative to other companies in the network can expect greater information benefits (Soh, 2003). First of all, the central position provides the company with access to a lot of (different) information sources. A company that moves to a more central position within the network is exposed to knowledge from a greater number of companies as well as from a greater variety of companies. Secondly, the central position also provides a way for evaluating and improving the information received from each source (Rowley, Behrens and Krackhardt, 2000). According to Bell (2005), central firms are more involved in their network (see also Wasserman and Faust, 1994), and by this are better able to compare information across sources, assess its veracity, are less likely to miss vital information, and can combine information in novel ways to generate innovation (Van de Ven, 1986).

Positional embeddedness provides access to and control over resources and by this is likely to be highly associated with innovation (Knoke and Burt, 1983; Powell et al., 1996; Wasserman and Faust, 1994). Powell et al. (1999) have analyzed the effect of positional embeddedness on company performance in the biotechnology industry. They conclude that once companies move to a central position in the network, their innovative performance will increase. Positional embeddedness clearly enables a company to select and complete research projects that prove to be worthy of innovation. Ahuja (2000a) reports that both the number of direct ties and the number of indirect ties (which can be seen as indicators of positional embeddedness) have a positive influence on a firm's innovative activities, i.e. innovation seems to need positional embeddedness. Following the above described literature, the following hypothesis can be formulated: 
Hypothesis 3: The higher a company's positional embeddedness, the higher the likelihood that it has a higher innovative performance.

\subsubsection{The effect of positional embeddedness on R\&D partnership formation}

The structural sociological perspective of alliance formation behavior argues that the patterns of inter-firm partnerships reflect the prior patterns of relationships (Gulati, 1995, 1999; Gulati and Gargiulo, 1999; Walter et al., 1997). A firm's ability to form new alliances is determined by the opportunities provided by its position in the prior network structure (Ahuja, 2000b). In the early stages of the evolution of a network, cooperation is based on direct relations and the structure is more or less governed by direct reciprocity. Over time, however, the reliance of companies on their previous relations for the choice of partners decreases. Third party relations and positions become more important for the choice of partners and companies within the alliance network may refer interesting partners to each other (Burt, 1992; Buskens and Raub, 2002; De Man, 2004; Lazega, 2000). Positional embeddedness increases the awareness of a company with respect to its possibilities to ally with other companies in the network and substitutes in part for personal experience with partners (Jansen, 2004).

Besides being aware of potential partners, companies must also have information about the needs, requirements, and reliability of these partners (Balakrishnan and Koza, 1993). Information about previous partners may be shared between the network members, thus making it easier to get in touch with new reliable partners (Burt, 1992; De Man, 2004). Access to valuable information like this can lower risks and their associated costs, and by this make it more likely to enter into new partnerships (Gulati, 1999).

So, positional embeddedness plays an important role in shaping the flow of information that enables companies to learn about new alliance opportunities with reliable partners (Buskens and Raub, 2002; Granovetter, 1985; Gulati, 1995, 1999; Kogut, Shan and Walker, 1992; Lazega, 2000) and has important behavioral and performance implications for companies' alliances (Gulati, 1998). Being embedded in a network of relations and having access to resources through different partners influences the decision of firms on whom to tie up with. Consequently, positional embeddedness is an important factor in explaining the alliance formation process (Gulati, 1995; Gulati and Gargiulo, 1999; Powell et al., 1996; Walker et al., 1997).

Evidence with respect to the effect of a firm's positional embeddedness on the likelihood of entering new alliances indeed reveals that central firms enter subsequent alliances more frequently than firms that are less central situated in the network (Eisenhardt and Schoonhoven, 1996; Gulati, 1997, 1999; Gulati and Gargiulo, 1999; Hagedoorn, Roijakkers and Van Kranenburg, 2006; Kogut et al, 1992; Podolny and Stuart, 1995; Powell et al., 1996, 1999). Furthermore, according to Lazzarini (2005), alliances are more likely to emerge when alliance networks exhibit a network structure characterized by high centralization. The effect of centralization suggests that the 
formation of alliances tends to be triggered by leading actors directly connected to other network members (Lazzarini, 2005). In line with the above mentioned arguments, the following hypothesis is formulated:

Hypothesis 4: The higher a company's positional embeddedness, the higher the likelihood that it forms new $R \& D$ partnerships.

\subsubsection{The effect of R\&D partnership formation on positional embeddedness}

Previous studies show that firms with more prior partnerships are more central in the network and entered more frequent into new partnerships (Kogut et al., 1992; Gulati, 1997). The number of partnerships a company forms is clearly linked to positional embeddedness in a positive way. Powell et al. (1996) argue that the greater the number of partnerships, the higher the company's central connectedness, i.e. its positional embeddedness. Per definition, each new R\&D partnership enhances the positional embeddedness of the participating companies by not only increasing the number of direct ties (with its partners) but also by increasing the number of indirect ties (with its partners' partners). Therefore, cooperative R\&D increases positional embeddedness, although moving to a central position in the network takes time and involves multiple linkages with different partners (Powell et al., 1999). Hence:

Hypothesis 5: The higher the number of new R\&D partnerships a company forms, the higher the likelihood that it has a higher positional embeddedness.

\subsection{Introducing multiple causal relationships}

In order to capture the dynamics between positional embeddedness, $R \& D$ partnership formation and innovation, it is important to look at multiple causal relationships instead of just single causal relationships. The evidence of the singular causal relationships mentioned in the variety of empirical studies described above suggests a Matthew effect (Grodal, 2004; Merton, 1968). The basic idea of the Matthew effect is that of a positive (or negative) feedback loop in which the rich are getting richer and the poor are getting poorer. Here, the Matthew effect refers to the situation in which already dominant companies (i.e. innovative companies) constantly increase their innovative performance even further by increasing their level of alliance formation and positional embeddedness.

First, as has been described before, R\&D partnership formation is expected to have a positive effect on a company's positional embeddedness (hypothesis 5). Furthermore, research has shown that a company's positional embeddedness within an alliance network facilitates innovative performance (hypothesis 3). Finally, innovative activity seems to foster the formation of new R\&D partnerships (hypothesis 2). One 
part of the dynamic is that the combination of these singular causalities suggests a positive feedback loop between alliance formation and innovation. This means that companies with many partnerships will occupy a more central position within the alliance network, increasing their innovative performance, thereby favoring the formation of new alliances in the future.

Second, as already has been discussed, research has shown that positional embeddedness within an alliance network facilitates the formation of new alliances (hypothesis 4). Furthermore, alliance formation is expected to positively influence a company's innovative performance (hypothesis 1). This means that companies that are already in a more central position within an alliance network, will likely become more actively involved in inter-firm R\&D partnerships, and thereby are expected to become increasingly innovative. The combination of the singular causalities as described above covers the other part of the dynamic by suggesting a second positive feedback loop between $\mathrm{R} \& \mathrm{D}$ alliances and innovation.

When combining the two feedback loops described above, an important double feedback loop occurs (see Figure 4.1). Not only do innovative firms experience an increased likelihood of entering into new R\&D partnerships, thereby enhancing their positional embeddedness which in the end affects innovative performance in a positive way. At the same time, being positional embedded within an alliance network facilitates the formation of $R \& D$ partnerships which in turn enhances the innovative performance of firms.

\subsection{Research methods}

\subsubsection{Data and sample}

We present a statistical analysis of a large international population of 3124 R\&D partnerships covering the years 1990-2000, which we obtained from the MERIT-CATI database (see Appendix A). These 3124 partnerships are sponsored by 1697 companies from 39 countries. $18.76 \%$ of these R\&D partnerships are joint ventures and $81.24 \%$ are contractual $R \& D$ partnerships. Furthermore, $47.25 \%$ of these R\&D partnerships are domestic partnerships, whereas $52.75 \%$ have an international nature. We study four industries: pharmaceuticals $(55.60 \%$ of the partnerships and $49.09 \%$ of the total number of sponsoring companies), computers (10.63\% and $13.80 \%$ respectively), semi-conductors $(27.08 \%$ and $27.39 \%$ respectively), and telecom $(6.69 \%$ and $9.72 \%$ respectively). These industries are generally accepted as high-tech industries because of their R\&D intensity, level of new product development, and patent intensity (OECD, 1992).

As already has been said, this chapter focuses on high-tech sectors and $R \& D$ partnerships because the research on alliances and innovation is consistent with the widely held belief that alliance networks form a "locus of innovation" in high-tech fields (Powell et al., 1996), with the emphasis on partnerships as mechanisms to access 
or transfer technological knowledge and to facilitate innovative efforts (Baum, Calabrese and Silverman, 2000; Mody, 1993; Teece, 1992). High-tech industries are a major area of industrial activity where companies forge an increasing number of partnerships (Chung, Singh and Lee, 2000; Gomes-Casseres, 1996; Hagedoorn, 2002) and it is in these industries where a large number of companies are engaged in joint R\&D through a variety of different modes of R\&D partnerships (Hagedoorn 1993; Soh, 2003).

Following some recent suggestions for a more multiple causal approach (Grodal, 2004), this chapter will attempt to contribute to the above mentioned body of literature by analyzing the multi-causal relationships and the resulting feedback loops between alliance formation, positional embeddedness and innovative performance of companies using one and the same dataset.

\subsubsection{Variables and method}

\subsubsection{Dependent and independent variables}

This chapter analyzes the existence of one model in which the singular causal relationships between R\&D partnership formation, positional embeddedness and innovative performance of companies are linked with each other (multi-causal perspective). Hypotheses 1-5 predict innovative performance, $R \& D$ partnership formation and positional embeddedness for companies in our sample. We take these in turn, meaning that these three variables in this study are both independent and dependent variables (see also Powell et al., 1996, 1999).

Innovative performance will be measured by counting the number of granted US patents from the US Patent and Trademark Office (USPTO) each company received per year (see also Appendix B). Several authors (Griliches, 1990; Kamien and Schwartz, 1982; Scherer and Ross, 1990) conclude that patents are an important measure of innovation output because they are directly related to inventiveness, they represent an externally validated measure of technological novelty, and they confer property rights on the assignee and therefore have economic significance. Research by Hagedoorn and Cloodt (2003) indicates that, in high-tech sectors such as those studied in this chapter, counts of patents are adequate indicators of the overall technological performance of companies. In our study, US patents will be used because the USA is the largest technology marketplace in the world, and it has become routine for non-US firms to patent in the USA (Albert, Avery, Narin and McAllister, 1991).

$R \& D$ partnership formation will be measured by calculating the number of R\&D alliances that each firm has formed in each year, starting in 1990 and ending in 2000. The focus is on high-tech industries in which we find large numbers of interfirm $R \& D$ partnerships, and where the interconnection between $R \& D$ partnership formation and innovative performance is highly relevant and important. Furthermore, the focus of this chapter is on newly formed R\&D partnerships, instead of total R\&D 
partnerships as in other studies. The reason for this is that our main goal is to investigate multiple causal relationships and to prove the existence of the model as a whole. Innovativeness of firms is said to affect the formation of new alliances (not total alliances). Furthermore, new alliances alter a firm's positional embeddedness and new alliances also enable access to new knowledge and thereby affect innovative performance. Besides, we are well aware of the additional effect of alliance experience as discussed in the literature, so we add partnership experience as one of the control variables in our study.

Positional embeddedness is measured by Freeman's (1979) closeness centrality measure using UCINET VI, a widely used network analysis program (Borgatti, Everett and Freeman, 2002). The measure we use is of a discrete nature. The measure is a variant of the measure used by Wasserman and Faust (1994) who use a relative measure. By using a discrete measure, all regression analyses can be performed by means of negative binomial models, thereby enhancing the comparison between the different models. Closeness is an inverse measure of centrality in that a larger value indicates a less central actor while a smaller value indicates a more central actor. Because our variable should measure centrality, a negative of the value is used to indicate that higher values indicate a more central position. Closeness centrality may be defined as the total graph-theoretic distance of a given node from all other nodes. More precisely,

$$
C_{i}=\sum_{j} d_{i j}
$$

where $d_{i j}$ is the number of links in the shortest path from actor $\mathrm{i}$ to actor $\mathrm{j}$. Closeness centrality is a measure of independence from the control of others. It is a measure of network activity and measures how well connected a company is in the overall network. It is said that companies that are more embedded in the network have greater opportunities because they have choices. They may have access to, and be able to call on more resources (information, knowledge) of the network as a whole. This autonomy makes them less dependent on any specific other company, and hence more powerful (Hanneman, 2001). Contrary to degree centrality, closeness centrality focuses on the path rather than direct ties alone, so each specific company in the network is still considered to be connected (reachable) through intermediaries. Indeed, Gulati and Gargiulo (1999) show how companies benefit not just from their direct ties, but also from the ties of the companies to whom they are connected (i.e. their indirect ties). It is said that companies who are able to reach other companies at shorter path lengths or who are more reachable by other companies at shorter path lengths, have favored positions (Hanneman, 2001).

\subsubsection{Control variables}

Size is included as a control variable, because it is expected that the intensity of strategic technology alliances will increase with the size of the companies. Larger 
firms may have wider-reaching industry contacts and by this leading to more extensive networks and greater knowledge of alliance opportunities (Eisenhardt and Schoonhoven, 1996). Furthermore, the size of a company is said to have a positive effect on its innovative performance (George, Zahra and Wood, 2002). It is conventional to control for firm-size effects in analyses of innovative productivity (Cohen and Levin, 1989) and alliance activities (Gulati, 1999). In our study, the size of each company included in the database is measured by the natural logarithm of the number of employees. This information was accessed through the well-known databases Worldscope and Amadeus.

$R \& D$ expenditures of companies are taken as a control variable because it is expected that their R\&D expenditures are likely to be a determinant of their innovative performance. Studies by Griliches (1998), Hausman, Hall and Griliches (1984), Kamien and Schwartz (1982), Mairesse and Mohnen (2005) and Scherer (1984) indicate a direct relation between the R\&D efforts of companies and their patenting output, although the relation may not be a linear one. The variable R\&D expenditures is measured by the natural logarithm of a firm's R\&D expenditures on a yearly basis. In order to compare R\&D expenditures of companies from different countries, all R\&D expenditures are transformed into US dollars. This information was accessed through the well-known databases Worldscope and Amadeus.

Partnership experience is included as a control variable because the experience of companies with setting up partnerships is known to affect their partnering behavior positively (e.g. Gulati, 1995; Ring and Van de Ven, 1992). Furthermore, the impact of collaboration on innovation increases in case companies have more alliance experience (Lane and Lubatkin, 1998; Mowery et al., 1996). Companies that have a lot of experience with managing alliances are for instance better able to reduce lead times or to integrate complementary knowledge which in the end may increase innovation (De Man and Duysters, 2005). The variable alliance experience refers to the natural logarithm of the number of years of alliance experience, which is measured as the time since the beginning of a company's first R\&D partnership. This variable was calculated for each company in each year by subtracting the first year of alliance experience from the current year.

Sectoral innovativeness is measured by the natural logarithm of the number of granted USPTO patents at the sector level for each year. This variable is included because the relevance of patenting differs between industries (Cohen et al., 2000).

Network centrality refers to the overall centralization of the network (sometimes referred to as global centrality) and is measured by the network centralization index using UCINET VI (Borgatti, Everett and Freeman, 2002). It measures how unequal the distribution of centrality is across all firms by measuring the extent to which the network as a whole looks like a star network. A star network is a network in which one actor is optimal central and connects to all other actors, i.e. the central actor acts as an intermediary for all other actors (Freeman, 1979; Hanneman, 2001). This variable is included in order to control for the possible effects that the degree of centrality at the network level has on a company's individual centrality level and its innovative 
performance. Structural network characteristics can affect the performance of the firms in an industry (Gulati et al., 2000, Meagher and Rogers, 2004; Walker et al., 1997).

\subsubsection{Statistical method}

All the dependent variables in our model are non-negative integer-valued count variables for R\&D partnership formation, positional embeddedness and innovative performance. Non-negative integer-valued count variables violate one of the main assumptions of the classical linear (OLS) regression model as the dependent variable can not be normally distributed. For such data, count models provide a methodological improvement over the classical linear regression model (Cameron and Trivedi, 1986; Gourieroux, Montfort and Trognon, 1984a, 1984b; Hausman, Hall and Griliches, 1984). The Poisson model is the simplest and more restricted count data model that assumes equality of the conditional mean and variance. However, a large number of empirical distributions of count data have a variance greater than the mean and are thus over-dispersed relatively to the Poisson case (Cameron and Trivedi, 1986; Wooldridge, 2002). The negative binomial regression is an extension of the Poisson model and provides a mechanism for incorporating over-dispersion while allowing the variance of the process to differ from the mean (Cameron and Trivedi, 1986; Gourieroux et al., 1984a, 1984b; Hausman et al., 1984).

The model as depicted in Figure 4.1 is a recursive model because it contains lags. When looking at Figure 4.1, it can be seen that for instance $R \& D$ partnership formation at time $t-1$ has an effect on innovative performance at time $t$ and innovative performance at time $t$ has an effect again on $R \& D$ partnership formation at time $t+1$. It is clear that these different effects of $R \& D$ partnership formation and innovative performance on each other don't happen at the same time, i.e. they don't happen simultaneous. Furthermore, the model is clearly a recursive model and not a nonrecursive (or so-called simultaneous equation model) because $R \& D$ partnership formation at time $t$ is not determined by positional embeddedness at time $t$.

In case of classical linear (OLS) data, the relationships between R\&D partnership formation, positional embeddedness and innovative performance could be analyzed using path analysis. Unfortunately, it is not possible to perform path analysis with the dataset in this study for two reasons. First of all, as already has been explained, the variables in our model are non-negative integer-valued count variables, so we have to use a count model. Secondly, the arrows in the model should all lead to one (or several) dependent variable(s) and there should not be any arrows in the model that point in the opposite direction (in this case, the model will blow itself up because the beginning and the end of the model is not clear).

When performing three separate regressions with the use of count data analysis, the error terms of the three regressions could be correlated with each other. That is why it is important to perform a test which measures the correlations between the 
residuals of the three analyses. In case the correlations are low enough, the results of the regressions are reliable and can be used in order to explain the model as a whole.

\subsection{Results}

Table 4.1 presents the descriptive statistics and the correlations for the variables included in the analysis. The table suggests that there are no significant problems with multicollinearity across the main independent variables used in the negative binomial analyses. There is also little correlation between the independent variables and the control variables. One exception is the correlation between the variable patents on the one hand and some control variables (size and R\&D expenditures) on the other hand, as well as the correlation between some control variables (size, R\&D expenditures and alliance experience). This collinearity does not affect the coefficient estimates but it can affect the stability of the estimated coefficients (Ahuja and Katila, 2001). To ensure that our estimated coefficients are stable, we omitted one of the two correlated variables from our analysis. The results of the sensitivity analysis stayed the same for all but the omitted variable. In other words, the sign and the significance of the affected variables did not change and we can conclude that our results are robust. Therefore, we decided to include all control variables in our model since they represent theoretically different constructs.

Next, we have to choose which count model to use for our analysis. In order to choose between the Poisson model and the negative binomial model we tested the equality of the conditional mean and variance, which is the most important distributional assumption of the Poisson model. The tests show that our data are overdispersed (i.e. the variance exceeds the mean), understating the computed standard errors in the Poisson regressions. In this case, the negative binomial model is to be preferred to the Poisson model for calculating the regression coefficients (Cameron and Trivedi, 1986).

As already has been said, hypotheses 1-5 predict innovative performance, R\&D partnership formation and positional embeddedness for the companies in our sample. We take these in turn, meaning that the variables in this study are both independent and dependent variables (see also Powell et al., 1996, 1999). Tables 4.2 - 4.4 provide the estimation results of the negative binomial analyses. The first analysis deals with the effect of R\&D partnership formation on positional embeddedness (Table 4.2), the second analysis deals with the effect of innovative performance and positional embeddedness on R\&D partnership formation (Table 4.3), and the last analysis deals with the effect of $R \& D$ partnership formation and positional embeddedness on innovative performance (Table 4.4). The models in Tables $4.2-4.4^{7}$ were significant overall, as indicated by the chi-square test using their log-likelihood values.

\footnotetext{
${ }^{7}$ Besides the results shown in Tables $4.2-4.4$, we also performed additional analyses including interaction effects, sector dummies, year dummies and trend variables. The findings showed mixed results, which could be a consequence of right hand censoring and data limitations.
} 


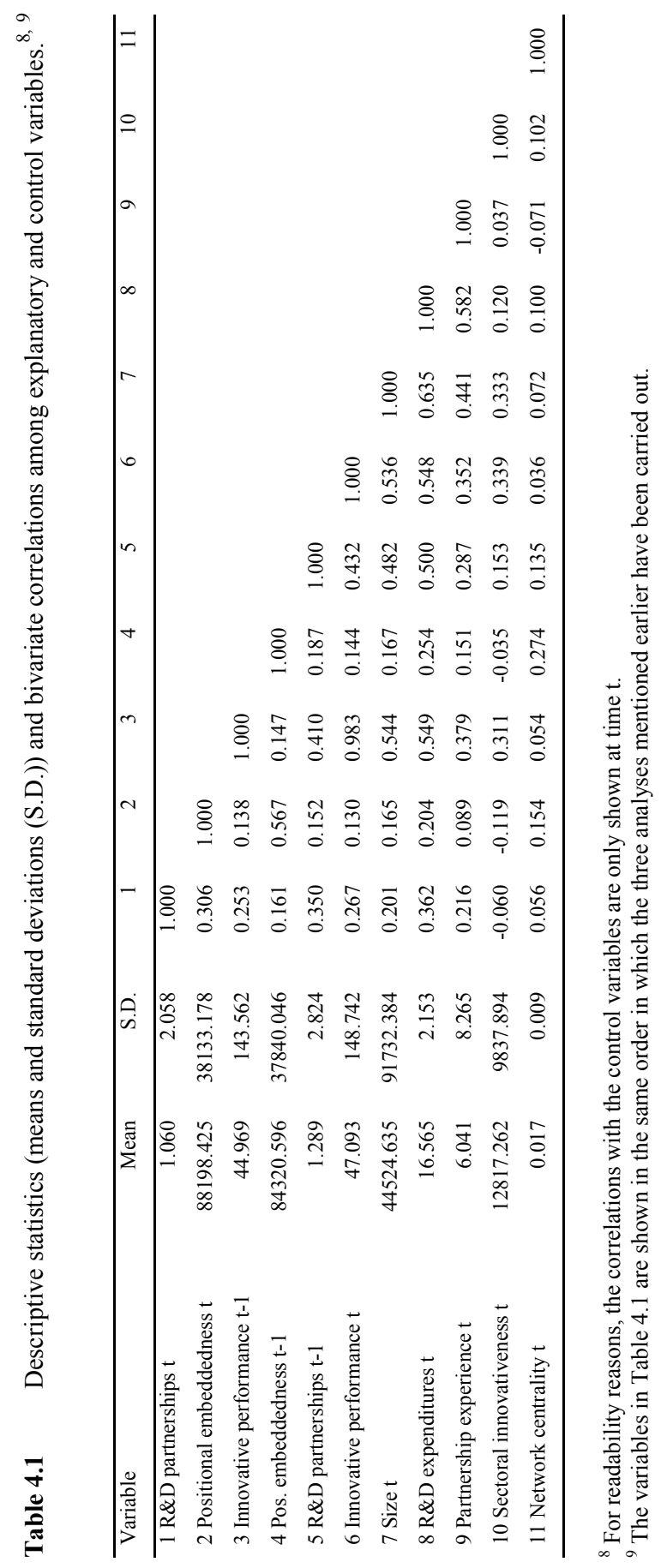


Table 4.2 The effect of R\&D partnership formation on positional embeddednes: results of the negative binomial analysis.

\begin{tabular}{ll}
\hline & Dependent Variable (at time $\mathrm{t}$ ) \\
\cline { 2 - 2 } Predictor Variables (at time $\mathrm{t})$ & Positional embeddedness \\
\hline Constant & $-10.4062^{* * * *}$ \\
& $(0.4841)$ \\
R\&D partnerships & $0.0309^{* * *}$ \\
& $(0.0103)$ \\
Size & $0.0600^{* * *}$ \\
& $(0.0212)$ \\
R\&D expenditures & -0.0230 \\
& $(0.0246)$ \\
Partnership experience & -0.0049 \\
Sectoral innovativeness & $(0.0032)$ \\
& $-0.1578^{* * *}$ \\
Network centrality & $(0.0397)$ \\
& $23.6647 * * * *$ \\
Log L & $(3.7242)$ \\
Chi-square & -6357.699 \\
\hline Standard errors in parentheses. & $9498284.0000^{* * * *}$ \\
$* * * *$ significant at $\mathrm{p}<0.001 ; * * *$ significant at $\mathrm{p}<0.01 ; * *$ significant at $\mathrm{p}<0.05 ; *$ significant at $\mathrm{p}<0.10$. \\
\hline
\end{tabular}

The results from Table 4.2 confirm hypothesis 5, which suggest that the more companies enter into new $\mathrm{R} \& \mathrm{D}$ alliances, the more these companies move to a more central position within the network. As can be seen from Table 4.2, the formation of R\&D alliances has a significant positive effect on the variable positional embeddedness at the 0.01 significance level.

The expected positive influence of innovative performance and positional embeddedness on the formation of new alliances is supported by the results in Table 4.3 (hypotheses 2 and 4). The results show that the innovativeness has a significant positive effect on the formation of new R\&D partnerships at the 0.05 significance level. This indicates that the more innovative companies are very attractive partners for engaging into new R\&D partnerships. Furthermore, the effect of a company's central position within the network on alliance formation is also positively significant at the 0.05 level. Firms that are in a central position have better opportunities to engage into new R\&D partnerships.

Hypothesis 1 and 3 state that the formation of R\&D partnerships and the position a company has within the network have a positive effect on the company's 
innovative performance. The coefficient for R\&D partnership formation is significant and positive at the 0.01 level, which clearly supports hypothesis 1 (see the results in Table 4.4). Also, positional embeddedness is significant at the 0.01 level and has a positive effect on innovative performance, thereby supporting hypothesis 3 .

Table 4.3 The effect of innovative performance and positional embeddedness on $\mathrm{R} \& \mathrm{D}$ partnership formation: results of the negative binomial analysis.

\begin{tabular}{ll}
\hline \multirow{2}{*}{ Predictor Variables (at time $\mathrm{t}-1)$} & Dependent Variable (at time t) \\
\cline { 2 - 2 } & R\&D partnerships \\
\hline Constant & $-2.4691^{* *}$ \\
& $(1.1997)$ \\
Innovative performance & $0.9524^{* *} \sim$ \\
& $(0.4309)$ \\
Positional embeddedness & $0.0036^{* *} \sim$ \\
& $(0.0017)$ \\
Size & $-0.0015 \sim$ \\
& $(0.0391)$ \\
R\&D expenditures & $0.2237 * * * *$ \\
Partnership experience & $(0.0633)$ \\
& -0.0032 \\
Sectoral innovativeness & $(0.0103)$ \\
& $-0.0192^{* *} \sim$ \\
Network centrality & $(0.0089)$ \\
Log L & 0.4434 \\
Chi-square & $(10.3290)$ \\
\hline Standard errors in parentheses. & -505.7087 \\
$* * * *$ significant at $\mathrm{p}<0.001 ; * * *$ significant at & $\mathrm{p}<0.01 ; * *$ significant at $\mathrm{p}<0.05 ; *$ significant at $\mathrm{p}<0.10$. \\
\hline multiplied by 1000 for readability reasons. & \\
\hline
\end{tabular}

Finally, we performed a test in order to check if the residuals of the three negative binomial analyses are not too much correlated with each other. Table 4.5 shows that the correlations between the three residuals are small enough to conclude that our results are reliable indeed.

To ensure the robustness of the findings, several control variables postulated in prior research were included. As expected, firm size shows significant positive effects on positional embeddedness as well as on innovative performance. Also, there exists a significant positive effect of $R \& D$ expenditures on $R \& D$ partnership formation as well 
as on innovative performance. The results indeed do confirm the expected positive effect of sectoral innovativeness on a firm's innovative performance. Furthermore, it turns out that there exists a significant positive effect of network centrality on positional embeddedness.

Table 4.4 The effect of R\&D partnership formation and positional embeddedness on innovative performance: results of the negative binomial analysis.

\begin{tabular}{ll}
\hline & Dependent Variable (at time t) \\
\cline { 2 - 2 } Predictor Variables (at time t-1) & Innovative performance \\
\hline Constant & $-9.7032^{* * * *}$ \\
& $(0.8723)$ \\
R\&D partnerships & $0.0349^{* * *}$ \\
& $(0.0125)$ \\
Positional embeddedness & $0.0031^{* * *} \sim$ \\
& $(0.0012)$ \\
Size & $0.1689^{* * * *}$ \\
& $(0.0391)$ \\
R\&D expenditures & $0.4620^{* * * *}$ \\
Partnership experience & $(0.0492)$ \\
Sectoral innovativeness & 0.0054 \\
& $(0.0054)$ \\
Network centrality & $0.4512^{* * * *}$ \\
Log L & $(0.0645)$ \\
Chi-square & -0.7622 \\
\hline Standard errors in parentheses. & $(5.4921)$ \\
$* * * *$ significant at $\mathrm{p}<0.001 ; * * *$ & significant at $\mathrm{p}<0.01 ; * *$ significant at $\mathrm{p}<0.05 ; *$ significant at $\mathrm{p}<0.10$. \\
$\sim$ multiplied by 1000 for readability reasons. \\
\hline
\end{tabular}

Somewhat surprisingly, the results show a negative effect of sectoral innovativeness on positional embeddedness and alliance formation by firms. Additional analysis with a squared term for this variable, not reported here, does indicate a non-linear relationship between sectoral innovativeness and these two dependent variables. For companies active in an industry with a relatively low level of sectoral innovativeness, an increase in sectoral innovativeness will result in an increase in R\&D partnership formation and positional embeddedness. However, for companies that are active in an industry that already has a relatively high level of sectoral innovativeness, a further 
increase in this innovativeness will have a negative effect on their R\&D partnership formation and positional embeddedness. The findings show no significant effects of size on the formation of R\&D alliances, of network centrality on R\&D partnership formation and innovative performance, and of $R \& D$ expenditures on positional embeddedness. The coefficient of partnership experience does not show any significant effects on the main variables, i.e. we cannot conclude that higher levels of partnership experience will result in higher R\&D partnership formation, higher positional embeddedness and higher innovative performance. Hoang and Rothaermel (2005) have also found a non-significant effect of partnership experience on performance.

Table 4.5 Descriptive statistics (means and standard deviations (S.D.)) and bivariate correlations between the residuals of the three negative binomial analyses (see Table 4.2, 4.3, 4.4).

\begin{tabular}{lrrrrr}
\hline Variable & Mean & S.D. & 1 & 2 & 3 \\
\hline 1 Residuals analysis 1 (see Table 4.2) & -440.0203 & 36499.5832 & 1.000 & & \\
2 Residuals analysis 2 (see Table 4.3) & 0.0209 & 2.6581 & -0.058 & 1.000 & \\
3 Residuals analysis 3 (see Table 4.4) & 2.0201 & 150.1687 & 0.002 & -0.018 & 1.000 \\
\hline
\end{tabular}

\subsection{Discussion and conclusions}

Thus far, studies of the implications of R\&D partnership formation, positional embeddedness and innovative performance on each other have proceeded separately, only looking at one singular relationship at a time. Yet, these singular relationships are interconnected with each other and merit consideration together. Based upon the earlier theoretical approach by Grodal (2004) and her suggestions for future research on the one hand, and the empirical findings of previous research as described above on the other hand, this chapter contributes to the already existing literature. This research empirically analyzed the multiple causal relationships between alliances, positional embeddedness and innovation. This study is carried out for a large number of interfirm R\&D partnerships, from a variety of industries, from countries worldwide, over a long period of time, thereby contributing to the generalizability of the findings in the chapter.

When combining the above discussed relationships, two feedback loops occur (see Figure 4.1). The first feedback loop shows that the formation of R\&D alliances has significant positive effects on a company's network position. By engaging in new R\&D alliances companies are able to move to a more central position within their alliance network, although this takes time and involves multiple linkages with different partners (Powell et al., 1999). Furthermore, the findings of this chapter show that positional embeddedness facilitates innovative performance (see also Ahuja, 2000a; Powell et al., 1999). Finally, innovative activity on its turn fosters the formation of 
new alliances. This indicates that the more innovative companies are very attractive partners for engaging into new R\&D partnerships. Because by working together with these kind of companies, a firm can increase its own knowledge base and its own dynamic capabilities, and thereby enhancing its own innovative performance (see also Ahuja, 2000b; Podolny et al., 1996; Stuart, 1998, 1999). These results unfold the first positive feedback loop that exists between $R \& D$ partnership formation and innovative performance.

Furthermore, there exists a second positive feedback loop between a company's R\&D alliance formation and its innovative activities. The findings from this chapter show that being centrally positioned within the network facilitates the formation of new alliances. These findings are consistent with the work of Eisenhardt and Schoonhoven (1996), Gulati (1997, 1999), Gulati and Gargiulo (1999), Hagedoorn et al. (2006), Kogut et al. (1992), Podolny and Stuart (1995) and Powell et al. (1996, 1999). Next to positional embeddedness on the firm level, network centrality also seems to play a role. There exists a positive effect of network centrality on the positional embeddedness of firms. A network that is highly centralized consists of a few central firms and many peripheral firms. Highly centralized networks provide a seemingly unlimited potential for novel combinations between firms. $R \& D$ partnerships are more likely to emerge when alliance networks exhibit a network structure characterized by high centralization. The effect of centralization suggests that the formation of alliances tends to be triggered by leading actors directly connected to other network members (Lazzarini, 2005). Firms may quit relations with less central players and invest in new relations with more central players, thereby increasing their own positional embeddedness. It seems that in highly centralized networks there is a greater need for individual firms to improve their own position within the network.

Besides, R\&D partnership formation turns out to positively influence a company's innovative performance. R\&D partnerships act as mechanisms to access or transfer technological knowledge, to develop and maintain absorptive capacity and to facilitate innovative efforts (Ahuja, 2000a; Baum et al., 2000; Cohen and Levinthal, 1990; Mody, 1993; Powell et al., 1996; Stuart, 1998; Teece, 1992; Zaheer and Bell, 1995). This all means that companies that are already in a more central position within an alliance network, will likely become more actively involved in inter-firm R\&D partnerships, and thereby are expected to become increasingly innovative. These findings are consistent with previous literature that shows that firms with more prior partnerships, are more central in the network, and entered more frequent into new alliances (Gulati, 1997; Kogut et al., 1992). The combination of the singular causalities as described above cover the other part of the dynamic by revealing a second positive feedback loop between R\&D alliances and innovation.

Interestingly, when combining the two feedback loops described above, an important double feedback loop occurs (see Figure 4.1). Not only does the formation of R\&D partnerships increase innovation, which increases R\&D partnership formation again, but $R \& D$ partnership formation also provides more central connectedness within the alliance network, which on its turn increases R\&D partnership formation as 
well as innovation. The findings in this chapter support the so-called Matthew effect, referring to the situation in which already innovative companies constantly increase their innovative performance even further by increasing their level of R\&D partnership formation and positional embeddedness.

In order to understand the relationships between R\&D partnership formation, positional embeddedness and innovative performance, it is important for companies to be aware of the vicious cycle as discussed above. An implication of the above described model is that first movers will be at an advantage by establishing a central role within the alliance network earlier and thereby benefit from the double feedback loop of innovation. Firms with a rich history of prior alliances are likely to move to a more central position within their network and increase their innovative capabilities, thereby increasing the likelihood of becoming attractive partners for engaging into new alliances. Meanwhile, firms that do not participate that much into inter-firm partnerships may never be able to increase their innovative capabilities and may even never be able to get themselves to enter into a new alliance. Managers could choose to anticipate such concerns about their participation in alliance networks by proactively initiate inter-firm contacts (preferable with central firms) in order to enhance their innovative capabilities and to enter into new alliances (see also Gulati, 1999).

This chapter was the first attempt to analyze the relationships between R\&D partnership formation, positional embeddedness and innovative performance using multi-causal relationships with the use of one and the same dataset. Future research could extend the current study by using these multi-causal relationships in order to find support for the idea of the existence of "one dynamic alliance-innovation model" (as suggested by Grodal, 2004), which shows a co-evolution of R\&D alliance formation, positional embeddedness and innovation within an alliance network context. A company's network position within an alliance network in particular, and the structure of the alliance network itself in general, are sensitive for changes. It is these structural changes that seem to raise the most fundamental strategic problems for companies in competition (see also Porter, 1981). Instead of using separate analyses as in the current study, future research could analyze the different relationships within one model, thereby revealing the consequences of the systemic dynamics of the model.

The current study concentrates on inter-firm $R \& D$ partnerships in high-tech industries (i.e. pharmaceuticals, telecom, computers and semiconductors) and the resulting effects of the multiple causal relationships between alliance formation, positional embeddedness and innovative performance. Future research could extend this study by examining these multiple causal relationships using a wider range of inter-firm partnerships that cover marketing or production and supply within a broader range of sectors (including medium- and low-tech sectors). Also, a better understanding of the actual transfer of knowledge in R\&D partnerships could benefit from research using a wider range of detailed firm-level indicators and more sophisticated sectoral characteristics than those currently available.

Furthermore, future research could include the effect of the diversity of ties (making a distinction between direct and indirect ties and/or between redundant and 
non-redundant ties) as additional or moderating factors in the model as analyzed in this chapter. When investigating the possible effects of these multiple causal relationships, future research could make a distinction between incremental innovations and radical innovations (that shape the future of industries, thereby altering the position of companies).

Another interesting topic of research would be the question what the magnitude of the different effects of R\&D partnership formation, positional embeddedness and innovative performance are on each other. Does alliance formation and positional embeddedness indeed have such significant positive effects on innovative performance? Or could it maybe be that pre-alliance effects, such as the positional embeddedness and the patenting behavior of the company before engaging into an alliance, are the dominant factor in explaining innovative performance. Our results show evidence for the so-called Matthew effect in which innovative companies increase there innovative performance even further. It would be interesting to investigate the effects of alliance formation and positional embeddedness on the innovative performance of companies when taking into account companies' prealliance positional embeddedness and pre-alliance innovation. Maybe alliance formation and positional embeddedness do not have that much an effect at all on innovation, but rather does innovation in the past lead to even more innovation in the future. 



\section{CHAPTER 5}

\section{THE STRENGTH OF R\&D NETWORK TIES IN HIGH-TECH INDUSTRIES: A MULTI-DIMENSIONAL ANALYSIS OF THE EFFECTS OF TIE STRENGTH ON TECHNOLOGICAL PERFORMANCE}

\section{$5.1 \quad$ Introduction}

Network ties, whether at the level of individuals or at the level of companies, can be described in various ways but central to many contributions to social network theory is the concept of tie strength (see for instance Granovetter, 1973; Jack, 2005; Krackhardt, 1992; Rowley, Behrens and Krackhardt, 2000). The analysis of the effect of tie strength, in terms of weak ties or strong ties, based on Granovetter's (1973) seminal contribution, has had a profound impact on the current management and organization literature. So far most of this literature has analyzed these network ties in the context of individuals and small groups behavior, see Perry-Smith and Shalley (2003) for a review of a large part of this literature. Although social network theory has also influenced the analysis of the behavior of companies and other organizations, there is still a relatively small number of studies that concentrate specifically on the effect of strong and weak ties in an inter-organizational network setting (see also Jack, 2005).

In the following, we will attempt to contribute to the body of literature on interorganizational network ties, in an analysis of the effect of strong or weak ties on the technological performance of companies in international high-tech industries. A central question in that context is whether companies in high-tech industries such as pharmaceuticals, computers, semiconductors, and telecom, should forge strong or weak ties with other companies through R\&D partnerships that can improve their technological performance. As demonstrated in a number of studies, high-tech industries are a major area of industrial activity where companies forge an increasing number of inter-firm linkages (Chung, Singh and Lee, 2000; Gomes-Casseres, 1996; Hagedoorn, 2002). It is also in these industries, where a large number of companies are engaged in joint R\&D through a variety of different modes of R\&D partnerships (Hagedoorn, 2002; Soh, 2003).

When companies engage in R\&D partnerships, the strength of their network ties through these partnerships emerges as an important topic when they face a range of strategic considerations regarding the partners with whom they might cooperate. Major strategic concerns focus on which companies to collaborate with, what sort of ties to build, how close a partner should be, how long the collaboration should last, and how frequent partners should engage in different partnerships over a longer period of time. Although much of the current literature on inter-organizational ties has taken a more one-dimensional perspective, these different questions already indicate that network 
ties might refer to a multi-faceted phenomenon. Following some suggestions for a more multi-dimensional approach (see for instance McEvily and Zaheer, 1999), we will analyze the effect of inter-firm network ties from a multi-dimensional perspective that returns to some basic elements of the original contribution by Granovetter (1973).

The empirical setting of our study is a large international population of more than three thousand R\&D partnerships, established in the four high-tech industries, introduced in the above. Nearly 1700 companies from 39 countries sponsor these R\&D partnerships, established during the period 1990-2000. So far most studies on the effect of inter-organizational network strength consider only domestic, in particular US, ties within one or two industries. Also, with the exception of a few studies (for instance Bruederl and Preisendoerfer, 1998; Rao, Davis and Ward, 2000) most other contributions refer to relatively small datasets.

In the next section, we will first discuss the current literature on interorganizational network ties, by considering in particular the pro's and con's of strong or weak ties that might benefit companies that engage in inter-firm partnering. For obvious reasons, our theoretical considerations will focus on the expected effect that network tie strength might have on the technological performance of companies that engage in $R \& D$ partnerships. This is followed by a discussion of the possible shortcomings of a more narrow understanding of the concept of tie strength and the possible benefits of a broader multi-dimensional perception. After explaining the benefits of a multi-dimensional measurement of tie strength, major elements of this approach are placed in the context of the current literature on inter-firm partnership formation. The section on the research methods provides some details on the population that we analyze and our data sources, it also introduces the variables used in the empirical analysis. This is followed by a brief outline of the results, which are discussed further in the last section, in the context of both the theoretical and methodological implications of our study.

\subsection{Theoretical background}

In Granovetter's (1973) original contribution to social network analysis, network ties were analyzed in terms of a movement along a continuum from weak to strong ties, in which this continuum is a function of the amount of time, emotional intensity, intimacy, and reciprocity within a relationship between network actors. In addition to this, Granovetter's differentiation of network ties also refers to the degree of similarity or dissimilarity of social circles in which a relationship is established (Granovetter, 1973). The basic argument of Granovetter (1973) was that a weak tie, through the combined effect of these different dimensions of tie strength, generates more relevant new information to a network actor than a strong tie, because a weak tie is more likely to generate a non-redundant connection between different social circles or local networks. 
This non-redundant connection, also known as a structural bridge, is a unique direct tie between two networks, where no other direct or indirect ties connect the two local networks that surround actors (Burt, 1992; Granovetter, 1973, 1982; Perry-Smith and Shalley, 2003). In the context of inter-firm partnerships, a structural bridge is created when a company is connected to another company while the first company is not directly connected to any of the other companies in its partner's network. According to the weak ties approach, stronger ties are less likely to act as a bridge, because two companies connected through a strong relationship are expected to become familiar with the other companies in each other's network (Granovetter, 1973). If the connection between two companies is a strong tie, additional partnerships are expected to gradually form between both companies and the other companies in their networks. As a result, the tie between both companies will no longer function as a structural bridge because of the frequency of interaction with others and the tendency for similarity in the networks of these strongly tied companies. The connections of one of the two main companies with various other companies will become similar as they will interact frequently through partnerships while also creating partnerships with the other main company. Through this interaction companies create interrelated local networks that, according to the weak ties approach, are running the risk of containing a high degree of redundancy.

Due to their structural properties, weaker ties are more likely to link companies to different local networks than stronger ties that are found between companies that share similarities in their partnerships (Granovetter, 1973; Krackhardt, 1992). Weaker ties also involve lower levels of interaction that do not depend on similarity between companies. Therefore, companies connected by weak ties are more likely to be dissimilar because they are not embedded in the same interconnected network of partnerships that are, to some extent, shaped by similarities. Consequently, weaker ties are more likely to connect distant companies with diverse and unique perspectives, different activities, and diverse problem-solving styles (Granovetter, 1982; Ruef, 2002).

These weaker ties also give access to a wider range of potential partners and more, non-redundant information (Burt, 1992; Granovetter, 1973, 1982; Weimann, 1983). Granovetter (1973) demonstrates this point, using the argument that the best way to spread gossip is through weak ties. If we understand gossip to be only a specific form of information, then information flowing through a strongly tied network tends to be redundant and travel circular paths as a company will tend to receive the same information from different companies. However, the information that passes through a weaker connection that acts as a structural bridge will reach different companies and not circulate back to its source. This information is expected to reach more and more companies that are farther removed from the original source of information. From the perspective of the company at the receiving end of the exchange, information traveling across a weak connection is more likely to be new and diverse relative to what the company is already aware of, because it emerges from 
distant companies outside the company's local network (see also Granovetter, 1982; Weimann, 1983).

Gaining access to diverse local networks and to non-redundant information provided by weak ties should also facilitate a more diverse information gathering process, relevant for our understanding of innovation and the technological performance of companies. Exposure to different approaches and new perspectives can enhance important innovative skills, such as the ability to generate technological alternatives and to engage in flexible thinking (Granovetter, 1982; Hagedoorn and Duysters, 2002a; Schilling and Steensma, 2001). Exposure to alternative technologies and different approaches may stimulate a company to pursue previously unexplored directions, to find unexpected knowledge spillovers, and to experiment with new ideas in such a way that these weak ties have a positive effect on its technological performance (Feldman and Audretsch, 1999; Kogut, 2000; Liebeskind et al., 1996; Ruef, 2002). This is similar to the effect of exploratory learning or non-routinized learning that involves changes in company routines and experimentation with new opportunities that change the capabilities of companies and increase their technological performance (Dodgson, 1993; March, 1991).

Interestingly, a small number of contributions seem to suggest exactly the opposite logic, where strong network ties of companies generate better results than weak ties. According to Krackhardt (1992), strong ties may be beneficial, for instance by providing a strong social environment and mutual support for network players. Larson (1992) understands the importance of strong ties for entrepreneurial firms in the context of a long-term perspective on ties that creates relational trust and reciprocity in information exchange between partners. Kraatz's (1998) study of the US private higher education sector reveals that strong ties instead of weak ties enable organizations to better adapt to environmental changes as organizations with strong ties learn from their well-connected environment. Leung-Kwong Wong and Ellis (2002) found that weak ties did play a role in the initial search process for Sino-Hong Kong international joint ventures, but in the final selection process of partners, when trust became more important, decisions were primarily based on information provided by strong ties. Kale, Singh and Perlmutter (2000) stress that strong ties between companies create relational trust which then affects the degree to which companies can learn from their partnerships. Uzzi (1997) does not discuss inter-firm networks in the exact terms of the strength of ties, he focuses on the embeddedness of ties of interrelated firms, but his study does suggest that strong ties are more suited for creating trust, information transfer and learning. Jenssen and Koenig (2002), in their study of nearly one hundred entrepreneurs in Norway, also establish that strong ties are important channels for information transfer. Bruederl and Preisendoerfer (1998) examined entrepreneurial companies in Germany and found strong ties, in terms of support from family and friends, to be crucial resources for small business formation (see also Hoang and Antoncic, 2003; Lechner and Dowling, 2003). Hite and Hesterly (2001) argue that strong ties will play an important role at the initial stages of the growth of entrepreneurial firms when these strong ties can help these firms to 
overcome various challenges in terms of limited resource access and restricted financial support due to their liability of newness.

Also in the context of the effect of the strength of network ties on the technological performance of companies, at least part of the literature suggests a positive effect of strong ties on technological performance. Strongly tied networks tend to be densely populated with many companies that have a multitude of relationships with each other. This cohesion within networks involves somewhat similar information flows, joint activities and solid and reciprocal relationships that create a basis of trust between partners (see also Ahuja, 2000a; Brass, Butterfield and Skaggs, 1998; Kale, Singh and Perlmutter, 2000). Since trust is an important basis for knowledge sharing and joint learning (Brass et al., 1998; Liebeskind et al., 1996), companies can use their strong ties to take advantage of joint learning and knowledge spillovers, while avoiding the duplication of innovative efforts, to improve their technological performance. Through strong ties, companies can initiate new joint R\&D projects that share some common technological characteristics with their partners (Mowery, Oxley and Silverman, 1996; Stuart and Podolny, 1996). As companies with strong ties focus on joint innovative efforts, this will increase the competence and expertise in their technological domain (Rosenkopf and Nerkar, 2001) and improve their technological performance.

Given the moral hazard that companies face in R\&D partnerships where they exchange knowledge and jointly set up research projects, trust, social embeddedness, multiple interactions, and strong ties may be necessary to curb the willingness of some to pre-maturely defect from $\mathrm{R} \& \mathrm{D}$ partnerships but it also increases the willingness of partners to share information (Ahuja, 2000a; Pisano, 1989; Ring and Van de Ven, 1994). Weak ties may create unexpected opportunities for technological innovation, but strong ties increase the exchange and sharing of knowledge with a variety of trusted partners. Strong ties between companies create economies of scale and scope, and they enrich the knowledge base of companies in their existing technological domain where the connection of a range of incremental innovations is crucial for the overall technological performance of companies (Chesbrough and Teece, 1996; Freeman and Soete, 1997; OECD, 1992; Teece, 1996). Hence, we can formulate the following central hypothesis of this chapter:

Hypothesis 1: The stronger the network ties that companies are involved in through their inter-firm R\&D partnerships, the higher their technological performance.

\subsection{The measurement of tie strength}

If one takes a closer look at the actual measurement of the strength of network ties of companies in the inter-firm networks literature, one finds that most studies use a rather straightforward binary, categorical measurement. For instance, in their study of networks in the US steel and semiconductor industries, Rowley, Behrens and 
Krackhardt (2000) measure the strength of ties of companies in terms of the form of their inter-firm partnerships. Joint ventures, equity alliances and R\&D partnerships are combined as strong ties, whereas weak ties are related to marketing and licensing agreements. Ruef (2002) measures the strength of network ties of more than 700 US entrepreneurs in a setting of either strong network ties through family linkages and friends or weak network ties through business associates. A somewhat similar measurement is used by Leung-Kwong Wong and Ellis (2002) who describe strong ties as familial connections and close family-type friendship. Weak ties are understood as casual friends, business associates and acquaintances. Jenssen and Koenig (2002) take an even narrower perspective, they indicate the strength of network ties of entrepreneurs according to the role played by acquaintances (weak ties) or friends or close friends (strong ties). Rao, Davis and Ward (2000) measure strong network ties of companies defecting from the NASDAQ stock market to the New York Stock Exchange through the sum of all their non-duplicated interlocking directorates with other companies. Board memberships by third party organizations are considered as weak ties.

A small number of studies in the inter-firm networks literature make an attempt to measure the strength of inter-organizational network ties beyond this setting in terms of dichotomies. For instance, Nohria and Garcia-Pont (1991) rate the strength of network ties at a one-dimensional, nine-point scale in terms of the inter-organizational interdependence through different types of inter-firm linkages. McEvily and Zaheer (1999) measure the strength of network ties as the frequency of interaction of respondents for firms with a specific group of their advisors. Bruederl and Preisendoerfer (1998) measure strong ties of entrepreneurial firms in multiple industries as an index of support from multiple sources, i.e. spouses or life-partners, parents, friends and relatives. Weak ties are measured in terms of an index of support from other multiple sources such as business partners, acquaintances, former employers, and former co-workers. Kraatz (1998) uses a multiple measurement of the strength of network ties for 230 liberal arts colleges, in terms of the age of their network, the size of their network and their network heterogeneity or network homogeneity.

Interestingly, Granovetter's original contribution already went further than these later studies when he introduced a multi-dimensional understanding of the strength of network ties. This approach was based on a 'probably linear' combination of the five dimensions of network tie strength: amount of time, emotional intensity, intimacy, reciprocity within a tie, and degree of similarity of the social circles in which partners reside. Also, the individual and combined strength of these dimensions can be seen as a movement along a continuum from weak to strong ties (Granovetter, 1973). In other words, Granovetter's contribution seems to suggest both a continuous and a multi-dimensional understanding of the weakness or strength of network ties. The above indicates that compared to the breadth of the original description of the strength of network ties by Granovetter, the understanding and measurement of the strength of inter-organizational network ties in the current inter-firm network literature is, with 
only a few exceptions, of a rather narrow and binary nature. Given the attention for the strength of network ties in social network theory and the impact of Granovetter's contribution on the management literature, it seems relevant to retain some of the richness of the original understanding of this phenomenon. Obviously, Granovetter's contribution is not necessarily the ultimate standard against which all other attempts to measure the strength of network ties should be assessed. However, the ease with which large parts of the literature seem to equate a binary understanding of tie-strength with the original multi-dimensional and continuous interpretation is somewhat surprising. At the same time, information exchange, (joint) search for new options, learning, the impact of the level of cooperation, the similarity of (sub-) networks, and the degree of interaction are frequently discussed in the broader theoretical context of the understanding of inter-firm network ties, which suggests that a more multidimensional approach can enrich our understanding of the degree to which companies forge particular network ties.

\subsubsection{A multi-dimensional understanding of the strength of inter-firm network ties}

As a first step towards a more multi-dimensional understanding of the strength of inter-firm network ties, one can translate Granovetter's (1973) original description of the characteristics of network ties to inter-firm relationships, for instance through $R \& D$ partnerships, and arrive at a set of parallel indicators. For instance, the amount of time invested in a relationship can be determined by looking at the length of the history of the partnerships of a company, a frequently used indicator of the level of interaction with other companies (Chung, Singh and Lee, 2000; Gulati, 1995; Koka and Prescott, 2002). The intensity of the network ties of a company can be interpreted as the multitude of partnerships that a company has, which expresses the degree to which a company focuses on particular partners and has a special relationship with them through a number of partnerships (Dyer and Singh, 1998; Gulati, 1995; Hagedoorn and Duysters, 2002; Koka and Prescott, 2002; Soh, 2003).

Intimacy and the reciprocity within a relationship can be translated into the degree of cooperation through the organizational interaction of partners in terms of the share of the joint ventures of a company in all its partnerships. Contractor and Lorange (2002), Dussauge and Garette (1999), Hagedoorn (2002), and Osborn and Baughn (1990) discuss the relevance of the degree of inter-organizational interdependence and interaction for a range of inter-firm partnerships. Higher levels of inter-organizational dependence and organizational interaction are found in equity joint ventures and lower degrees of interaction refer to a range of other forms of partnering such as licensing agreements, second sourcing, and standard customer supplier agreements (see also Nohria and Garcia-Pont, 1991; Rowley et al, 2000).

The similarity of the social circles of partners can be captured by their cultural closeness and the similarity of these networks through partnerships with other 
companies. Given the international context of our study, the degree of cultural closeness can be understood in terms of domestic partnership formation and international cultural closeness. Domestic partnership formation will denote the share of domestic partnerships in the total of partnerships in which a company engages. This indicates the degree to which a company is seeking for network ties outside its domestic domain that are culturally different and less familiar than the ties that it has with companies in its well-known domestic environment (Buckley and Casson, 2002; Contractor and Lorange, 2002). International cultural closeness characterizes the degree to which a company has established partnerships with companies from countries that are culturally similar, or not (Kogut and Singh, 1988).

Similarity of the networks in which two or more companies find themselves can be understood in terms of their structural equivalence which indicates the degree of interaction with companies that operate in similar networks. Two firms are referred to as structural equivalent if they have identical ties to other firms. The measurement of structural equivalence specifies the degree to which a firm finds itself in a network of inter-firm ties that overlaps with the network of other firms (Hagedoorn and Duysters, 2002; Knoke and Kuklinsky, 1982; Wasserman and Faust, 1994).

As suggested by other research that considers the strength of network ties in a multi-dimensional setting (for instance Marsden and Campbell, 1984), factor analytical methods can be applied to indicate the degree of coherence between these different measures of tie strength. With the outcome of this partial analysis, one can construct an index of the strength of different ties that preserves the multi-dimensional character of the strength of network ties. A possible redefining of the boundaries between these dimensions and a further improvement of our understanding of these indicators and measures, seem interesting directions for both theoretical and empirical research on the strength of inter-firm network ties. Obviously, the strongest ties are still those that reach the higher levels for these indicators and dimensions, the weaker ties stay at the lower levels. In addition to this, such an approach will enable us to measure the possible dissimilar effects of different dimensions of the strength of network ties.

\subsection{Research methods}

\subsubsection{Population and data}

We present a statistical analysis of a large international population of 1697 companies, from 39 countries, with a total number of 3282 R\&D partnerships. The data on these R\&D partnerships were obtained from the MERIT-CATI database (see also Appendix A). $18.76 \%$ of these $R \& D$ partnerships are joint ventures and $81.24 \%$ are contractual R\&D partnerships. Furthermore, $47.25 \%$ of these R\&D partnerships are domestic partnerships, whereas $52.75 \%$ have an international nature. We study four sectors of industry: pharmaceuticals $(55.60 \%$ of the partnerships and $49.09 \%$ of the total number 
of sponsoring companies), computers (10.63\% and $13.80 \%)$, semi-conductors $(27.08 \%$ and $27.39 \%$ ), and telecom $(6.69 \%$ and $9.72 \%)$. These industries are generally accepted as high-tech industries because of their R\&D intensity, their level of new product development, and their patent intensity (OECD, 1997). Our research covers the period 1990-2000 for R\&D partnerships, with additional years for patents as the dependent variable (see also below).

There are several reasons for choosing these four international high-tech sectors and $R \& D$ partnerships as the empirical setting for our study. First, some recent studies suggest that strong ties are perhaps less relevant in high-tech industries than in other industries (Hagedoorn and Duysters, 2002; Rowley, Behrens and Krackhardt, 2000; Walker, Kogut and Shan, 1997). As our hypothesis suggests quite the opposite, testing the effect of strong ties on technological performance in high-tech industries seems an appropriate setting for falsification purposes. Second, R\&D partnerships build a dominant sub-category of partnerships in these high-tech industries (Hagedoorn, 2002) where there are also quite a large number of these partnerships, which enables us to test our central hypothesis on a large population. Third, given the internationalization of many industries, in which inter-firm partnerships play a significant role, it seems appropriate to analyze inter-firm network ties in an international context (OECD, 1992).

\subsubsection{Dataset}

As mentioned in the above, the dataset consists of 1697 companies (each firm with an R\&D partnership and its partner) that both sponsor $3282 \mathrm{R} \& \mathrm{D}$ partnerships. In order to arrive at a dataset to be used in a statistical analysis, a 'column' with data for each partner is copied to the 'column' for each firm, and vice versa. The actual dataset then consists of 6564 rows, each $R \& D$ partnership is represented twice. This procedure is compulsory as our analysis focuses on companies and all companies in the partner 'column' should also be represented in the firm 'column'. The measurement of dyadic indicators, for instance for structural equivalence in a pair, are assigned to both partners. This enables us to recalculate all variables from the dyadic (pair) level to the level of all individual companies, i.e. all 1697 companies.

Next, we calculated for each company the average value of each variable per year. If company X had five R\&D partnerships in e.g. 1995, i.e. there are five rows in the dataset with company $\mathrm{X}$ for 1995 , we calculated an average value for company $\mathrm{X}$ for 1995. This procedure was followed for all variables, in which the average for some indicators such as the R\&D expenditures within a year are not affected by the number of events, whereas the average value for variables such as structural equivalence is affected by the number of partners that each have in their own ego-network. If company $\mathrm{X}$ has five $\mathrm{R} \& \mathrm{D}$ partnerships, it can partner with five different companies that each can also have R\&D partnerships with other companies. In the end, the row 
for company $\mathrm{X}$ in 1995 will appear only once in the dataset. The implication of this is that the total number of companies in the dataset will remain 1697.

We cannot generate a panel dataset as there is a very large number of companies in our data with only one R\&D partnership during the whole period 19902000. The alternative would be to remove companies with only one $R \& D$ partnership from the dataset. This would result in a limited dataset with only 311 firms, i.e. only $18.3 \%$ of the original dataset. However, companies with only one R\&D partnership are clearly an integral part of the overall network of R\&D partnerships and deleting these companies from the dataset would not only seriously limit the number of companies, it would also have an artificial effect on all measures for network strength. In the end, we would arrive at a heavily biased dataset that would ignore a large part (over $80 \%$ ) of the relevant population of companies with R\&D partnerships.

\subsubsection{Dependent variable}

Our hypothesis associates the tie strength of the R\&D partnerships of companies with their technological performance. The technological performance of companies is measured by means of their patent applications. Research by Hagedoorn and Cloodt (2003) indicates that, in high-tech sectors such as those studied in this chapter, counts of patents are adequate indicators of the overall technological performance of companies. The actual measurements are: the number of patents of a company one year after it established one or more R\&D partnerships (variable patents 1), the number of its patents within two years after it formed at least one R\&D partnership (patents 2), and the number of its patents within three years (patents 3). These different time periods between joint R\&D and patent applications are based on suggestions in the literature (Cincera, 1997; Hall, Griliches and Hausman, 1986; Scherer, 1984).

Data on patents are taken from the US Patent and Trademark Office (USPTO) (see also Appendix B). Although this US data could imply a bias in favor of US companies and against non-US firms, the patent literature suggests several reasons to choose US patent data (see Patel and Pavitt, 1991). These reasons include the importance of the US market, the genuine patent protection offered by US authorities, and the level of technological sophistication of the US market, which makes it almost compulsory for non-US companies to file patents in the US.

\subsubsection{Independent variables, indicators and measures}

For each R\&D partnership established in a specific year, we calculated the value of each of the six tie strength indicators for each company that was engaged in that specific partnership. Some variables were first measured as dyadic or pairwise country indicators. However, in order to carry out a firm-level analysis, the values of these 
measures were assigned to both companies engaging in the partnership. In case a company had more than one partnership per year, we calculated the average value for each indicator per company per year. The reason for calculating average values per company per year is that our unit of analysis is the company, and not pairs of companies that engage in a partnership, i.e. we need one value per company per year in our dataset. These average values of the six indicators are then used to measure the strength of network ties for each company per year.

The indicator length is the average, per company and per year, of the period that a company has partnerships with each of its partners, going back to a maximum of five years before the start of the period covered by our research (see also Gulati, 1995).

The indicator multitude measures the average, per company and per year, number of multiple partnerships that a company has with some other companies. This equals the degree centrality (total number of partnerships) divided by the number of its partners.

The degree of cooperation through organizational interaction is the average, per company and per year, share of joint ventures in the total number of partnerships in which a company engages.

Network similarity is measured using the standard network indicator, structural equivalence. This measure is calculated by means of Pearson correlations that indicate the actual similarity of the networks of R\&D partnerships of companies. This procedure takes a company's row and column entries in a similarity matrix, compares them to the row and column entries of all other companies in the matrix and then calculates the degree of profile similarity between a company and each of the other companies. This comparison is made between every possible pair of companies in the matrix and the resulting profile similarity between each pair is measured using the Pearson product correlation coefficient for each pair. The greater the correlation for a pair of companies, the more structurally equivalent they are (Borgatti, Everett and Freeman, 2002; Hanneman, 2001).

It is important to keep in mind that our unit of analysis is at the firm level and not at the pair-level. In order to make a firm-level analysis possible, the pair-wise Pearson correlations are assigned to each individual company, participating in the partnership, after which the average value has been calculated per company and per year. The resulting variable network similarity is the, per company and per year, average value of these Pearson correlations.

Cultural closeness is measured by two indicators: international cultural closeness and domestic partnership formation. International cultural closeness measures the degree to which a company has established partnerships with companies from countries that are culturally similar. This measure uses the cultural distance formula from Kogut and Singh (1988) based on the four dimensions introduced by Hofstede (1980). Because this indicator should measure cultural closeness and not cultural differences as in the Kogut and Singh measure, a negative of the value is used to indicate that higher values indicate higher cultural closeness, i.e. stronger ties. This measure is in principle a pairwise country measure, because for each pair (and from 
both partners' country perspective) we can calculate this value for cultural closeness. However, for a firm-level analysis, these measures for cultural closeness have been assigned to each individual company in each partnership, which generated the average value per company and per year. The resulting variable cultural closeness is the average per company and per year value of the cultural closeness.

Domestic partnership formation indicates the average, per company and per year, value of the share of domestic partnerships in the total of number of partnerships in which a company engages.

In order to translate these multiple indicators of the strength of network ties into more general dimensions of network ties, we will perform an exploratory factor analysis to see which indicators contribute to the same factor or dimension. For all measures and factors, higher values indicate stronger network ties.

\subsubsection{Control variables}

Consistent with prior research on inter-firm partnerships, we included a number of control variables for specific company characteristics, for some general characteristics of the sectors of industries and the countries from which companies originate. $R \& D$ expenditures of companies are taken as a control variable because we expect that their R\&D expenditures are likely to be a determinant of their technological performance. Studies by Bound, Cummins, Griliches, Hall and Jaffe (1984), Griliches (1998), Hausman, Hall and Griliches (1984), Kamien and Schwartz (1982), Mairesse and Mohnen (2005) and Scherer (1984) indicate a direct relation between the R\&D efforts of companies and their patenting output, although the relation may not be a linear one. The variable $R \& D$ is measured by a company's $\mathrm{R} \& \mathrm{D}$ expenditures. In order to compare $\mathrm{R} \& \mathrm{D}$ expenditures of companies from different countries, all $\mathrm{R} \& \mathrm{D}$ expenditures are transformed into US dollars.

The literature indicates that the size of companies plays a role in the technological performance of companies. In that context it is argued that the patenting activity of companies increases with size (Cohen and Levin, 1989; Mansfield, 1986; Mueller, 1986; Scherer, 1984). The control variable size is measured in terms of the number of employees of a company. Information on the R\&D expenditure and the size of companies was accessed through well-known databases such as Amadeus, Compustat, Disclosure, Osiris, and Worldscope.

The relevance of patenting differs with regard to sectors (Cohen, Nelson and Walsh, 2000; Teece, 1987; Winter, 1987). In order to control for this, we included the variable patents sector, which measures the number of USPTO patents at the sector level.

For a somewhat similar reason, we included the variable patents country, which is measured by the number of USPTO patents applied for by companies from each country. 


\subsection{Results}

Table 5.1 presents the descriptive statistics and the correlation matrix for the variables of the exploratory factor analysis. Table 5.2 provides the results of the exploratory factor analysis. Data used for factor analysis have to be tested for sampling adequacy and significance (Hair, Anderson, Tatham and Black, 1995). The Kaiser-Meyer-Olkin measure of sampling adequacy and the anti-image correlations for the different measures are above the minimum level of 0.500. As can be seen in Table 5.2, all communalities are also above 0.500 , i.e. all variables have sufficient explanation in the model. Our analysis results in three factors with an eigenvalue larger than 1, i.e. our model contains three significant factors. The measures for length and multitude contribute to the same factor, which we interpret as the factor 'extent'. The measures for the degree of cooperation and similarity of network ties contribute to the intensity of the network tie, which we designate as the factor 'depth'. The two indicators of cultural closeness, i.e. international cultural closeness and domestic partnership formation contribute to a third factor, labeled 'cultural closeness'.

These three factors explain $65.39 \%$ of the total variance. Not surprisingly, the factor loadings exhibit the same overall pattern as the communalities (see Table 5.2). According to common social science practice, that uses a minimum cut-off point of 0.30 or 0.35 for factor loadings, our factor loadings are very high and very significant, making all variables very representative of the three factors (Hair, Anderson, Tatham and Black, 1995). We use the resulting factor scores to represent the factors in our subsequent statistical analyses. As the dependent variable refers to the number of patents, i.e. the dependent variable is a non-negative, integer-valued count variable, we will use a count data model. After testing our data for over-dispersion, it turned out that the negative binomial model is to be preferred to the Poisson model (Cameron and Trivedi, 1986).

Table 5.3 presents the descriptive statistics and correlations of the dependent variable and explanatory variables. Tables $5.4-5.6$ present the results of the negative binomial analysis with patents 1 (one year lead time), patents 2 (two years lead time), and patents 3 (three years lead time) as dependent variable, respectively. With very few minor exceptions the three tables tell much the same story, which enables us to focus on Table 5.4. In Table 5.4, model 1 only includes the control variables, models 2, 3, and 4 each include one of the three factors or network variables, and model 5, the full model, includes the control variables and all three factors (see also Tables 5.5 and 5.6). In each table, adding one of the factors or network ties variables to the basic model, with only the control variables, improves the log likelihood of the model significantly. The results of a chi-squared test for improvement of subsequent models are also reported in Tables 5.4 - 5.6. Compared to the other models, model 5, the full model, has the highest log likelihood value. 


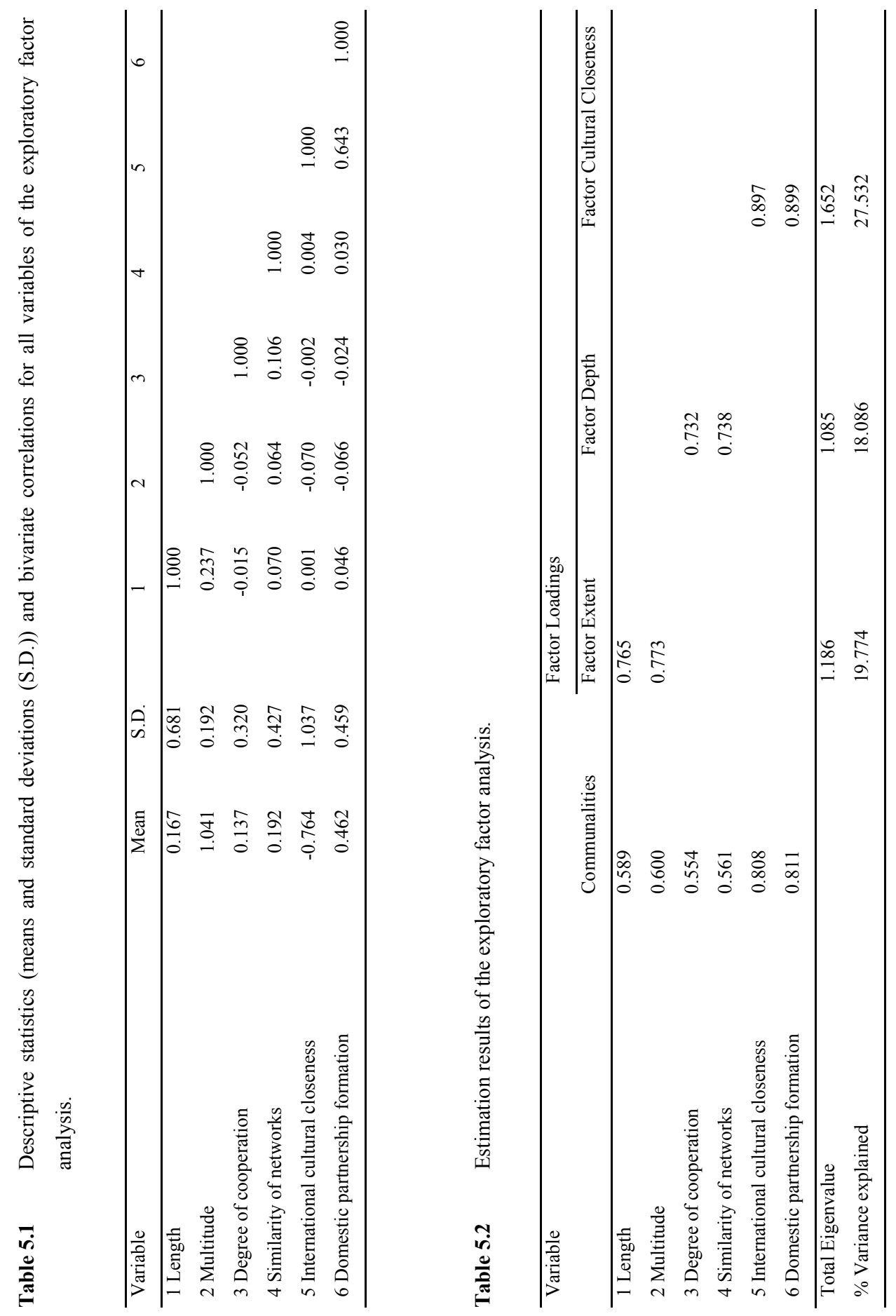




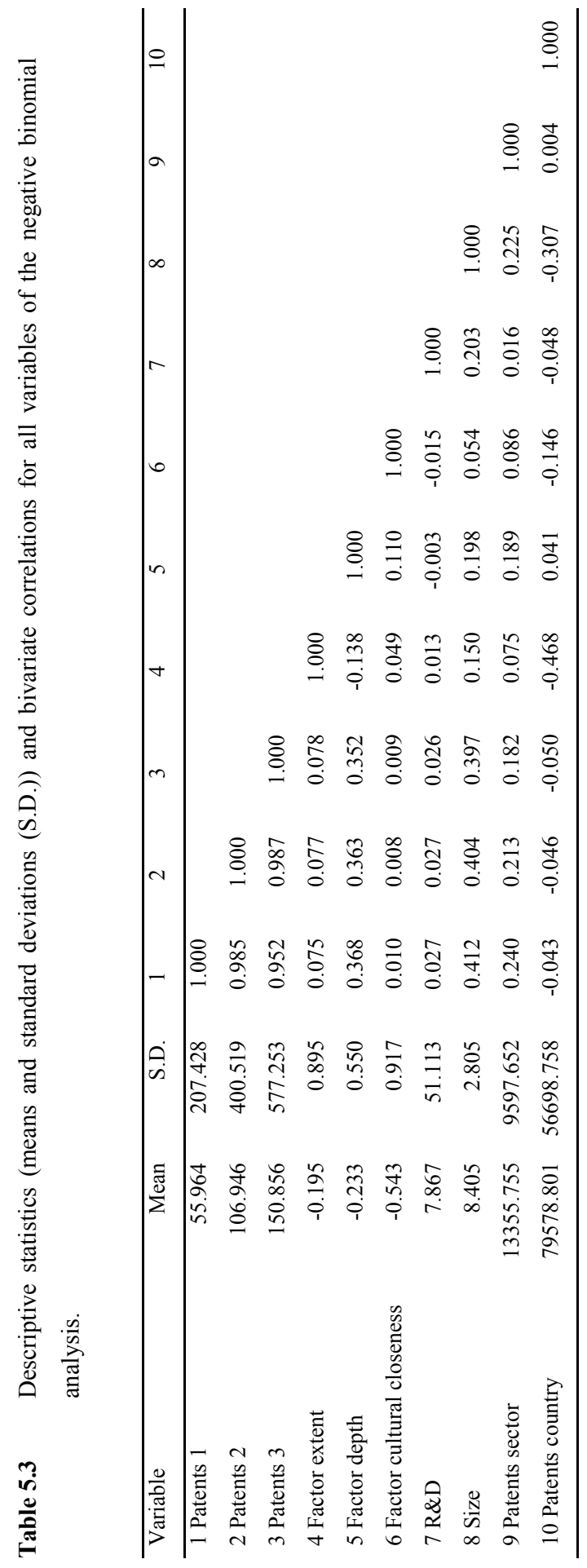


These findings generate partial support for the central hypothesis of this chapter. The factor depth, which refers to the degree of cooperation by means of joint ventures and the similarity of networks, has a significant and positive effect on the technological performance of companies in all relevant models. The factor extent, referring to the length of partnerships and the multitude of partnerships between companies, has a significant and positive effect in all but one of the relevant models. Obviously, both factors indicate that strong ties have a significant, positive effect on technological performance, but the factor depth (the degree of cooperation through joint ventures and the similarity of networks) appears to have the highest impact.

Table 5.4 Estimation results of the negative binomial analysis (one year lead time for the dependent variable).

\begin{tabular}{|c|c|c|c|c|c|}
\hline & Model 1 & Model 2 & Model 3 & Model 4 & Model 5 \\
\hline \multirow[t]{2}{*}{ Constant } & $-1.0730^{* * *}$ & $-1.1937^{* * *}$ & $-0.6902^{* * *}$ & $-1.1575^{* * *}$ & $-0.8911^{* * *}$ \\
\hline & $(0.1730)$ & $(0.1832)$ & $(0.2035)$ & $(0.1754)$ & $(0.2120)$ \\
\hline \multirow[t]{2}{*}{ Factor extent } & & $0.1459^{* *}$ & & & $0.1500^{* *}$ \\
\hline & & $(0.0703)$ & & & $(0.0694)$ \\
\hline \multirow[t]{2}{*}{ Factor depth } & & & $0.3192^{* * *}$ & & $0.3583^{* * *}$ \\
\hline & & & $(0.0959)$ & & $(0.1019)$ \\
\hline Factor & & & & $-0.2091^{* * *}$ & $-0.2140^{* * *}$ \\
\hline cultural closeness & & & & $(0.0626)$ & $(0.0628)$ \\
\hline \multirow[t]{2}{*}{$R \& D$} & $-0.0064^{* * *}$ & $-0.0063^{* * *}$ & $-0.0062^{* * *}$ & $-0.0065^{* * *}$ & $-0.0062^{* * *}$ \\
\hline & $(0.0022)$ & $(0.0021)$ & $(0.0021)$ & $(0.0021)$ & $(0.0021)$ \\
\hline \multirow[t]{2}{*}{ Size } & $0.5001^{* * *}$ & $0.5032^{* * *}$ & $0.4764^{* * *}$ & $0.5088^{* * *}$ & $0.4870^{* * *}$ \\
\hline & $(0.0163)$ & $(0.0163)$ & $(0.0175)$ & $(0.0164)$ & $(0.0176)$ \\
\hline \multirow[t]{2}{*}{ Patents sector } & $0.0496^{* * *}$ & $0.0475^{* * *}$ & $0.0447^{* * *}$ & $0.0495^{* * *}$ & $0.0425^{* * *}$ \\
\hline & $(0.0059)$ & $(0.0059)$ & $(0.0059)$ & $(0.0058)$ & $(0.0058)$ \\
\hline \multirow[t]{2}{*}{ Patents country } & -0.0016 & -0.0002 & $-0.0024^{* *}$ & $-0.0018^{*}$ & 0.0010 \\
\hline & $(0.0011)$ & $(0.0013)$ & $(0.0011)$ & $(0.0011)$ & $(0.0013)$ \\
\hline Log likelihood (L) & -6246.039 & -6232.429 & -6228.321 & -6229.512 & -6220.585 \\
\hline Log L change & & $(2)-(1)$ & (3)-(1) & $(4)-(1)$ & $(5)-(1)$ \\
\hline$\chi^{2}$ & & $27.220^{* * * *}$ & $35.436^{* * * *}$ & $33.054^{* * * *}$ & $50.908^{* * * *}$ \\
\hline
\end{tabular}

Standard errors in parentheses.

**** significant at $\mathrm{p}<0.001 ; * * *$ significant at $\mathrm{p}<0.01 ; * *$ significant at $\mathrm{p}<0.05 ; *$ significant at $\mathrm{p}<0.10$

Interestingly, the factor cultural closeness, the degree of domestic partnership formation and the international cultural closeness, has a significant negative effect on 
the technological performance of companies in all relevant models. This implies that from the perspective of cultural closeness, the weaker the network ties and the more international the ties of companies, the higher their technological performance.

Table 5.5 Estimation results of the negative binomial analysis (two years lead time for the dependent variable).

\begin{tabular}{|c|c|c|c|c|c|}
\hline & Model 1 & Model 2 & Model 3 & Model 4 & Model 5 \\
\hline \multirow[t]{2}{*}{ Constant } & -0.2266 & $-0.3160^{* *}$ & 0.2051 & $-0.3078^{* *}$ & 0.2862 \\
\hline & $(0.1389)$ & $(0.1456)$ & $(0.1632)$ & $(0.1408)$ & $(0.1685)$ \\
\hline \multirow[t]{2}{*}{ Factor extent } & & $0.1223^{* *}$ & & & $0.1328^{* *}$ \\
\hline & & $(0.0575)$ & & & $(0.0565)$ \\
\hline \multirow[t]{2}{*}{ Factor depth } & & & $0.3774^{* * *}$ & & $0.4184^{* * *}$ \\
\hline & & & $(0.0794)$ & & $(0.0843)$ \\
\hline Factor & & & & $-0.2135^{* * *}$ & $-0.2205^{* * *}$ \\
\hline cultural closeness & & & & $(0.0515)$ & $(0.0517)$ \\
\hline \multirow[t]{2}{*}{$\mathrm{R} \& \mathrm{D}$} & $-0.0053^{* * *}$ & $-0.0053^{* * *}$ & $-0.0051^{* * *}$ & $-0.0054^{* * *}$ & $-0.0051^{* * *}$ \\
\hline & $(0.0010)$ & $(0.0010)$ & $(0.0010)$ & $(0.0010)$ & $(0.0010)$ \\
\hline \multirow[t]{2}{*}{ Size } & $0.4907^{* * *}$ & $0.4952^{* * *}$ & $0.4639^{* * *}$ & $0.5000^{* * *}$ & $0.4740^{* * *}$ \\
\hline & $(0.0129)$ & $(0.0129)$ & $(0.0138)$ & $(0.0130)$ & $(0.0139)$ \\
\hline \multirow[t]{2}{*}{ Patents sector } & $0.0454^{* * *}$ & $0.0435^{* * *}$ & $0.0401^{* * *}$ & $0.0452^{* * *}$ & $0.0378^{* * *}$ \\
\hline & $(0.0049)$ & $(0.0049)$ & $(0.0049)$ & $(0.0048)$ & $(0.0048)$ \\
\hline \multirow[t]{2}{*}{ Patents country } & $-0.0020^{* *}$ & -0.0008 & $-0.0028^{* * *}$ & $-0.0022^{* *}$ & -0.0017 \\
\hline & $(0.0009)$ & $(0.0011)$ & $(0.0009)$ & $(0.0009)$ & $(0.0011)$ \\
\hline Log likelihood (L) & -7527.759 & -7507.669 & -7496.875 & -7502.129 & -7485.811 \\
\hline Log L change & & (2)-(1) & (3)-(1) & (4)-(1) & (5)-(1) \\
\hline$\chi^{2}$ & & $40.180^{* * * *}$ & $61.768^{* * * *}$ & $51.260^{* * * *}$ & $83.896^{* * * *}$ \\
\hline
\end{tabular}

Standard errors in parentheses.

$* * * *$ significant at $\mathrm{p}<0.001 ; * * *$ significant at $\mathrm{p}<0.01 ; * *$ significant at $\mathrm{p}<0.05 ; *$ significant at $\mathrm{p}<0.10$.

As for the effects of the control variables, it turns out that the variable for R\&D expenditures has a significant negative impact on the technological performance of companies. Additional analysis with a squared term for this variable, not reported here, does indicate a non-linear relationship between $R \& D$ expenditures and the dependent variable. This finding is consistent with the well-known literature in which R\&D expenditures demonstrate an inverse U-shaped function of the technological 
performance of companies (Scherer, 1984). For companies with a relatively low level of $R \& D$ expenditures, an increase in $R \& D$ expenditures will result in an increase in technological performance. However, for companies that already have a relatively high level of $\mathrm{R} \& \mathrm{D}$ expenditures, a further increase of these expenditures will have a negative effect on their technological performance.

As expected, the control variables size and sectoral patenting both have a significant positive impact on the technological performance of companies. The last control variable, patenting at the country level, does not have a significant effect on the technological performance of a company, i.e. we cannot conclude that higher levels of patenting at the country level will result in higher technological performance of companies from these countries.

Table 5.6 Estimation results of the negative binomial analysis (three years lead time for the dependent variable).

\begin{tabular}{|c|c|c|c|c|c|}
\hline & Model 1 & Model 2 & Model 3 & Model 4 & Model 5 \\
\hline \multirow[t]{2}{*}{ Constant } & 0.1419 & 0.0894 & 0.6007 & 0.0595 & $0.4537^{* * *}$ \\
\hline & $(0.1407)$ & $(0.1457)$ & $(0.1664)^{* * *}$ & $(0.1429)$ & $(0.1705)$ \\
\hline \multirow[t]{2}{*}{ Factor extent } & & 0.0884 & & & $0.1046^{*}$ \\
\hline & & $(0.0592)$ & & & $(0.0583)$ \\
\hline \multirow[t]{2}{*}{ Factor depth } & & & $0.4210^{* * *}$ & & $0.4600^{* * *}$ \\
\hline & & & $(0.0847)$ & & $(0.0895)$ \\
\hline Factor & & & & $-0.2197^{* * *}$ & $-0.2291^{* * *}$ \\
\hline cultural closeness & & & & $(0.0541)$ & $(0.0544)$ \\
\hline \multirow[t]{2}{*}{$R \& D$} & $-0.0055^{* * *}$ & $-0.0055^{* * *}$ & $-0.0053^{* * *}$ & $-0.0057^{* * *}$ & $-0.0054^{* * *}$ \\
\hline & $(0.0011)$ & $(0.0011)$ & $(0.0011)$ & $(0.0011)$ & $(0.0011)$ \\
\hline \multirow[t]{2}{*}{ Size } & $0.5036^{* * *}$ & $0.5044^{* * *}$ & $0.4752^{* * *}$ & $0.5136^{* * *}$ & $0.4856^{* * *}$ \\
\hline & $(0.0132)$ & $(0.0133)$ & $(0.0142)$ & $(0.0134)$ & $(0.0144)$ \\
\hline \multirow[t]{2}{*}{ Patents sector } & $0.0414^{* * *}$ & $0.0398^{* * *}$ & $0.0356^{* * *}$ & $0.0410^{* * *}$ & $0.0334^{* * *}$ \\
\hline & $(0.0052)$ & $(0.0053)$ & $(0.0052)$ & $(0.0051)$ & $(0.0052)$ \\
\hline \multirow[t]{2}{*}{ Patents country } & $-0.0029^{* * *}$ & $-0.0020^{*}$ & $-0.0038^{* * *}$ & $-0.0032^{* * *}$ & $-0.0030^{* * *}$ \\
\hline & $(0.0009)$ & $(0.0011)$ & $(0.0009)$ & $(0.0009)$ & $(0.0011)$ \\
\hline Log likelihood (L) & -7898.880 & -7878.786 & -7865.488 & -7872.440 & -7855.912 \\
\hline Log L change & & $(2)-(1)$ & (3)-(1) & $(4)-(1)$ & (5)-(1) \\
\hline$\chi^{2}$ & & $40.188^{* * * *}$ & $66.784^{* * * *}$ & $52.880^{* * * *}$ & $85.936^{* * * *}$ \\
\hline
\end{tabular}

Standard errors in parentheses.

$* * * *$ significant at $\mathrm{p}<0.001 ; * * *$ significant at $\mathrm{p}<0.01 ; * *$ significant at $\mathrm{p}<0.05 ; *$ significant at $\mathrm{p}<0.10$ 
We also experimented with some possible interaction effects that could indicate that the strength of network ties would work out differently, for instance in combination with sectoral patenting activity. However, none of the potentially interesting interaction effects tuned out to generate significant results.

\subsection{Discussion and conclusions}

Interestingly, some of the main findings of this chapter regarding the effect of the strength of network ties in an inter-firm network setting are somewhat similar to those presented in previous research on intra-organizational network ties of groups or departments within companies. For instance, Hansen (1999) demonstrates that there is no unequivocal answer to the question whether strong or weak ties between business units within a company increase its technological performance. However, his research does show that strong ties between business units facilitate the transfer of complex knowledge that in itself can contribute to an improved technological performance of the company. Somewhat comparable results are generated by Tsai (2001) who shows that business units within companies that maintain a large number of intraorganizational ties benefit from these ties through shared learning and extensive information exchange that improve their innovative output.

At the level of inter-organizational networks, when we consider the effect of the strength of inter-firm network ties in R\&D partnerships, some aspects of strong ties do indeed also improve the technological performance of companies. More precisely: network ties in inter-firm R\&D partnerships improve the technological performance of companies in high-tech industries through the actual strength of their depth-related dimensions and their extent-related dimensions. In particular the strength of the R\&D network ties of companies in terms of the depth of these ties has a positive effect on their technological performance. This depth-dimension of network ties refers to the combined effect of the degree of cooperation between companies and the similarity of their network ties and those of their partners. The intensive inter-organizational interaction by means of equity joint ventures (Contractor and Lorange, 2002; Dussauge and Garette, 1999; Osborn and Baughn, 1990; Rowley et al, 2000) and the similarity of the network ties of companies (Ahuja, 2000a; Saxton, 1997; Uzzi, 1997), i.e. the interaction with a similar group of companies as their partners interact with, enables companies to benefit from their network ties.

The second important dimension of strong inter-firm network ties, the aspect of extent, denotes the joint, positive effect of the amount of time invested in inter-firm relationships and their intensity or multitude (see also Chung, Singh and Lee, 2000; Dyer and Singh, 1998; Gulati, 1995; Koka and Prescott, 2002; Soh, 2003). The length of the history of partnerships and their multitude, that express the degree to which companies have a special relationship with each other, also have a significant effect on the technological performance of companies. 
These aspects of cohesive and strongly tied networks of R\&D partnerships encourage information flows, knowledge sharing, and joint learning through reciprocal and trusted relationships (Kale, Singh and Perlmutter, 2000; Pisano, 1989; Ring and Van de Ven, 1994). Information flows, knowledge creation and learning are important to innovation in many industries but in particular in high-tech industries. Joint R\&D activities through partnerships that combine these elements of the innovation process have become popular in many high-tech industries (Hagedoorn, 2002; Liebeskind et al., 1996; Soh, 2003). Through strong ties, in terms of the depth and extent of their partnerships, companies initiate joint $R \& D$ projects and other shared innovative activities that increase their technological performance in these industries within a relatively short period of time.

Although, the strength of these aspects of depth and extent in network ties only refers to some characteristics of social embeddedness or social capital (see Adler and Kwon, 2002), these results do indicate that the social embeddedness of companies can indeed positively influence their technological innovative performance (Ahuja, 2000a; Chung, Singh and Lee, 2000; Walker, Kogut and Shan, 1997). Our findings confirm the view on social embeddedness which implies that the higher the degree of social cohesiveness in a network environment, based on the density of ties, their common history, their interaction, and their similarity of partnerships, the more companies will benefit from the advantages created by the spillovers in their network environment. Companies with ties that are well-embedded in R\&D networks, characterized by solid, reciprocal, dense, and long-term trustworthy relationships do seem to benefit from the network externalities created by their R\&D partnerships with a variety of companies.

From a strong tie perspective, our negative findings on the third dimension of tie strength (cultural closeness) are counter intuitive. However, these findings can be explained in the context of a complex learning environment in which many high-tech companies operate. In a complex learning environment, some diversity of knowledge inputs from various sources is helpful to develop new technologies (Miller, 1996). International aspects of this learning environment expose companies to important new and diverse ideas from multiple international markets and different cultural perspectives (Hagedoorn and Duysters, 2000; Hitt, Hoskisson, Johnson and Moesel, 1996). Ghoshal (1987) and Hoecklin (1995) state that the diversity of international environments and cultures in which a company operates exposes it to multiple stimuli. It enables the company to develop diverse capabilities and it provides a broader learning opportunity than is available to a company that operates in a purely domestic environment. Hoskisson and Hitt (1994) show that multinational companies can exploit differences in national resources and competencies to generate the additional resources necessary to successfully operate large-scale $R \& D$ in an international context.

The environment pictured in the above, is relevant for a large number of industries but in particular for many high-tech industries that have become highly internationalized during the past decades (OECD, 1992). Although, our finding on the relevance of weak, internationally distant, tie characteristics seems surprising, it does 
indicate the importance of internationally diverse knowledge sourcing in high-tech industries. Similar findings are reported in a recent study by Contractor, Kim and Beldona (2002) on the international pharmaceutical and chemical industries, where international R\&D partnerships yield higher innovative returns than domestic partnerships. In combination with our results, these findings suggest that companies participating in international $R \& D$ partnerships with companies that are culturally distant have to engage in inter-organizational learning as they are confronted with new ideas from a variety of international markets and culturally different perspectives. Companies that use this diversity in external, international resources through joint innovative activities realize a higher technological performance than companies that participate in $\mathrm{R} \& \mathrm{D}$ partnerships with domestic companies or companies that are culturally close.

As discussed earlier, companies in international high-tech industries that are well-embedded in long-term $R \& D$ relationships within a cohesive network generate higher technological performance than those that are less embedded. Yet, in this age of international markets and international technology sourcing, it is important for companies to put this embeddedness in a broader international perspective, as a predominance of domestic $\mathrm{R} \& \mathrm{D}$ partnerships can have a negative effect on the technological performance of companies. In other words, R\&D network ties that are characterized by a combination of well-embedded ties, with solid, reciprocal, dense, and long-term trustworthy relationships, within a setting of international and culturally diverse inter-firm $R \& D$ partnerships seems to be beneficial for the technological performance of companies.

The above also indicates why it is not that much of a surprise that the empirical literature on the effect of the strength of inter-firm network ties generates rather conflicting insights. Most of the relevant studies use only one indicator of the strength of network ties, very often a binary measurement, nearly always in a domestic setting. In a complex international environment with a multitude of inter-firm relationships through a variety of organizational forms, the notion of a multi-dimensional understanding of the strength of network ties appears more adequate to capture this complexity than a simple one-dimensional measurement that seems merely born out of convenience. However, our findings also suggest that such a multi-dimensional understanding of the strength of network ties does not conform to a 'probably linear' combination of the different dimensions of tie-strength, as stated in Granovetter (1973). Our research indicates that the argument that a network should perhaps consist of both strong and weak ties to generate benefits to participants (Burt, 1992; Granovetter, 1973; Jack, 2005) can be qualified. The above suggests that it is not so much a balance in a portfolio of strong and weak ties but much more a combination of both strong and weak characteristics within individual network ties, in terms of their extent, depth, and cultural closeness, that create benefits to companies.

Obviously, there are a number of options for future research on this topic. Our research considers the effect of the strength of network ties on the technological performance of companies without differentiating between 'run-of-the-mill' 
innovations and radical innovations. The possible effect of network ties on radical innovations that shape the future of industries and that alter the position of companies is an interesting subject for subsequent research. Also, future research could consider a wider range of inter-firm partnerships that cover marketing, production, supply and for which the strength of network ties could perhaps have a different effect on the performance of companies. As noted in the above, much of the literature on tie strength has focused on inter-personal relationships within organizations whereas our contribution considers the effect of network ties in an inter-organizational context. A further extension of a multi-dimensional approach could benefit from research that would link inter-personal aspects of network ties with the different aspects of interorganizational network ties that are analyzed in this chapter. 


\section{CHAPTER 6}

\section{CONCLUSIONS}

\subsection{Introduction}

This final chapter provides an overview of the most important conclusions of this dissertation. We will seek to answer our general research question and to reflect on the results of our analyses. Furthermore, we will elaborate on the methodological, empirical, theoretical and managerial implications of our study. Finally, we will discuss the limitations of this thesis and provide suggestions for future research.

The main purpose of this thesis was to gain a better insight into the relationships between a firm's formation of new R\&D partnerships, its social embeddedness and its innovative performance. In line with social network theory, previous work introduced a differentiation of several levels of social embeddedness that affect the formation of new forms of economic organization such as inter-firm partnerships (Dacin et al., 1999; Granovetter, 1992; Gulati and Gargiulo, 1999; Hagedoorn, 2006; Hite, 2003; Lam, 1997; Simsek et al., 2003; Uzzi, 1997) and the innovative performance of the companies involved.

This study intended to contribute conceptually as well as empirically to the current body of literature on the social embeddedness of firms in the context of the formation of R\&D partnerships and innovative performance. This thesis made use of a multi-level approach of social embeddedness by making a distinction between environmental embeddedness (macro as well as meso level), positional embeddedness and relational embeddedness (see Figure 6.1). This multi-level approach of social embeddedness could help us to obtain more fine grained insights into the mechanisms driving R\&D partnership formation and the innovative performance of firms. By conducting a quantitative research project based on empirical analyses of the MERITCATI database (see Appendix A), in this thesis an attempt was made to answer the following general research question:

What is the relationship between a firm's $R \& D$ partnership formation, its social embeddedness and its innovative performance?

In order to answer this general research question, it was split into three more specific sub-questions, each of which was dealt with in a separate chapter. We first investigated the effect of the macro level of environmental embeddedness, in terms of intellectual property rights protection, as well as the meso level of environmental embeddedness, in terms of the level of technological change in the sector of industry, on the preference of a company for hierarchical control in an international $R \& D$ partnership. Our research focused on international R\&D partnerships from a wide 
range of industries (including high-tech, medium-tech, and low-tech industries) and for companies from a large number of countries by studying over 2000 international R\&D partnerships set up by nearly 2000 companies from 53 countries for the period from the mid-1970s to the end of the 1990s.

Figure 6.1 Multi-level approach of a firm's social embeddedness.

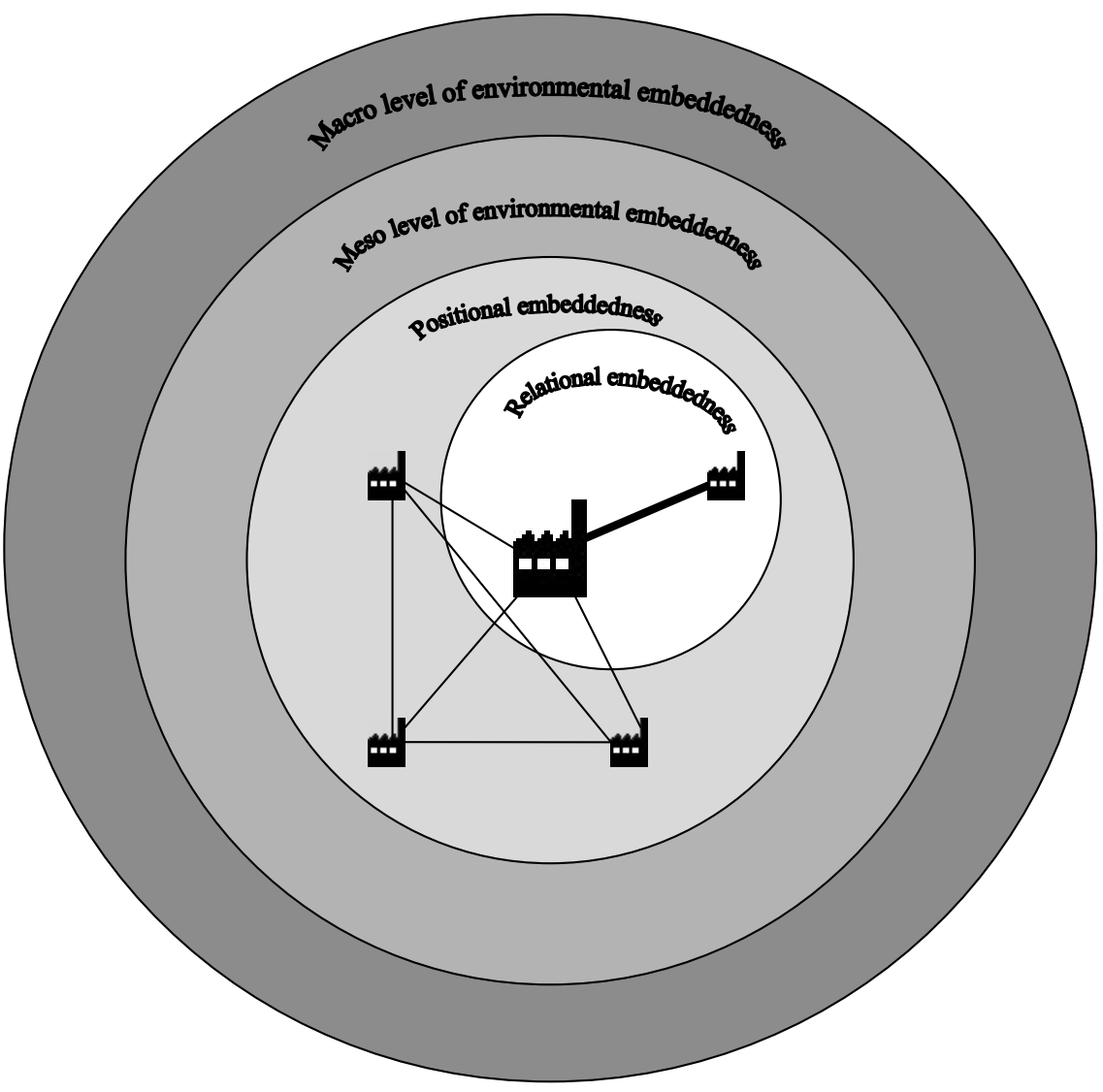

Next, we analyzed the effects that a company's R\&D partnership formation, its positional embeddedness and its innovative performance have on each other. Finally, we studied the effect of relational embeddedness of a company, in terms of strong and weak ties, on its innovative performance. The research of these two studies focused on more than 3000 R\&D partnerships (international as well as national) of nearly 1700 companies from 39 countries, established in 4 high-tech industries (pharmaceuticals 
including biotech, computers, semiconductors and telecom) during the period 19902000. The answers to the different specific sub-questions will enable us to answer our general research question.

In the next section we will discuss the main results of this study within the context of the different levels of social embeddedness, and provide an overall answer to the general research question of this thesis. Section 6.3 gives an outline of the methodological, empirical, theoretical and managerial implications of this thesis. Finally, Section 6.4 discusses the limitations of our study and provides some suggestions for future research.

\subsection{Some major findings of this thesis and answer to the general research question}

The improvement of innovation is an important component of a high-tech firm's strategy (Hamel, 2000) and is closely linked with a firm's R\&D partnership formation and its social embeddedness. The main purpose of this thesis was to gain a better insight into the relationship between the formation of new R\&D partnerships, a firm's social embeddedness and its innovative performance. In line with social network theory, this thesis made use of a multi-level approach of social embeddedness to obtain more fine grained insights into the mechanisms driving R\&D partnership formation and innovative performance of firms. A distinction was made between environmental embeddedness, positional embeddedness and relational embeddedness.

The distinction between the macro level and meso level of environmental embeddedness, positional embeddedness and relational embeddedness indicates different levels of a firm's social embeddedness that affect the behavior of firms as well as their performance. These different levels of a firm's social embeddedness play a role in explaining the behavior of firms in terms of their preference for particular forms of governance of international R\&D partnerships as well as in terms of their propensity to enter into future R\&D partnerships. Furthermore, these different levels of a firm's social embeddedness also play a role in explaining the performance of firms in terms of their innovative activities. In the following sections we will examine the role of a firm's environmental embeddedness, its positional embeddedness and its relational embeddedness in order to be able to give an answer to the general research question.

\subsubsection{The role of environmental embeddedness}

The literature on the choice that companies make with regard to the governance structure of joint activities, such as equity joint ventures and contractual partnerships, focuses on three main topics: the monitoring of the actual collaboration, the enforcement of contractual terms, and the adequate specification of property rights 
(Oxley, 1999; Pisano, 1989; Williamson, 1996). The particular aspects of decision making with regard to the mode of governance for inter-firm collaboration seem highly relevant for understanding international $R \& D$ partnerships. Joint $R \& D$, that in particular plays an important role in high-tech industries, is by definition an uncertain activity for which it is very difficult, if not impossible, to define ex ante both the complete results and their implications for future activities.

Furthermore, in case of international R\&D partnering, the international nature of collaboration only adds to the uncertain nature of the activity due to a lack of familiarity with circumstances in other countries and because the enforcement of contractual terms for international R\&D partnering largely depends on the specific legal system that regulates such partnerships. It is well known, that there are large international differences in contract law, while the actual enforcement of such laws is even non-existent in many countries (Ginarte and Park, 1997; Varsakelis, 2001). Most relevant in the current context are the international differences in intellectual property rights protection. Literature suggests that the more economically developed countries are, the more they have established a legal system that enforces contract law and the stronger their intellectual property rights protection (Marron and Steel, 2000; Varsakelis, 2001). The above suggests a number of important questions with respect to the preference of companies for international R\&D joint ventures or international contractual R\&D partnerships in the context of international differences in intellectual property rights protection and the role of technological change in their competitive environment.

First, at the macro level of environmental embeddedness, the strength of intellectual property rights protection in particular countries is expected to be an important institutional and environmental factor in the choices that companies make when they engage in international R\&D partnerships (Muralidharan and Phatak, 1999). Companies from a domestic environment characterized by substantial intellectual property rights protection are confronted with higher appropriability hazards and potentially subsequent costs when they engage in contractual agreements with companies from countries with relatively poorer conditions of intellectual property rights protection. Equity joint ventures are expected to be reserved for circumstances with such greater appropriability hazards because they offer managerial and organizational control and increase the possibilities for adequate monitoring and oversight (Oxley, 1999; Teece, 1986). Therefore, we investigated the effect of the level of intellectual property rights protection in the home country of the partner on a company's preference for hierarchical control in an international R\&D partnership.

Second, at the meso level of environmental embeddedness, literature suggests that the level of technological change in industries might influence the preferred form of governance for partnering companies (Auster, 1987; Hagedoorn and Narula, 1996; Harrigan, 1985, 1988; Osborn and Baughn, 1990; Yu and Tang, 1992). Therefore, we investigated the effect of the level of technological change in the sector of industry in which an international R\&D partnership is established on the preference of a company for hierarchical control in an international $R \& D$ partnership. 
Our results indicated that the preference of companies for hierarchical control, through a joint venture mode for international $R \& D$ partnering, is inversely related to the strength of intellectual property rights protection in the home country of their partner. Furthermore, our results suggested that establishing international $R \& D$ partnerships in industries characterized by higher levels of technological change decreases the likelihood that these partnerships take the form of equity joint ventures. Overall, it can be concluded that with respect to the behavior of firms, we found empirical evidence that indicates that the macro level of environmental embeddedness as well as the meso level of environmental embeddedness both play a role in the choice of governance structure when entering new international R\&D partnerships.

At the macro level of environmental embeddedness, intellectual property rights protection is an important aspect in the decision-making regarding international interfirm R\&D partnering. The emphasis in this study on R\&D partnerships highlights an important aspect of the appropriability hazards of shared activities, i.e. the possible leakage of knowledge. Apart from the fundamentally intrinsic uncertainty of R\&D, international cooperation without adequate safeguards to counter involuntary knowledge transfer, would further increase the uncertainty that already surrounds the outcome of joint R\&D. Joint ventures provide better protection and monitoring than incomplete contracting through $\mathrm{R} \& \mathrm{D}$ pacts and joint development agreements.

Furthermore, at the meso level of environmental embeddedness, the level of technological change in sectors of industry also affects the preference of companies for particular modes of governance for international $R \& D$ partnering. The more industries are characterized by intensive $\mathrm{R} \& \mathrm{D}$ and technological changes that create a constant flow of new products and new processes, the more flexibility and organizational change appear to be relevant for companies in those industries (Harrigan, 1988; Oster, 1992). In particular contractual R\&D partnerships play a major role in attempts made by companies to answer the need for organizational flexibility as they are constantly adjusting to frequent technological changes while monitoring new technologies and introducing crucial innovations themselves (Dussauge and Garetti, 1999; GomesCasseres, 1996; Oster, 1992).

\subsubsection{The role of positional embeddedness}

In research traditions that stress the importance of organizational learning and the transfer and diffusion of knowledge and innovative capabilities within a company and between companies, knowledge is a central issue (Grant, 1996) which can be generated within the firm (internally) or outside the firm (externally). External knowledge generation by means of alliances has become more and more important during the last decades. By making use of inter-firm collaborations, such as R\&D partnerships, firms can learn from each other's differences, generate new ideas and practices, generate new knowledge and create incentives for innovative behavior (Ahuja, 2000a, Cohen and Levinthal, 1989, 1990). 
Besides the larger amount of one-on-one alliances, firms are also increasingly embedded in networks of alliances (De Man, 2004). An important issue in that respect is the central position that a firm occupies within the alliance network since that determines its access to information and thereby to external knowledge. It is said that firms that occupy a central position within the alliance network are exposed to knowledge from a greater number of partner firms as well as from a greater variety of firms, and by this are more likely to increase their innovative activities (Powell et al., 1996). Furthermore, firms in central network positions have informational advantages that increase their propensity to engage in new R\&D partnerships (Burt, 1992; Freeman, 1979). These informational advantages also diminish information asymmetry problems associated with selecting partners (Knoke and Kuklinski, 1982; Wasserman and Faust, 1994) and make it easier to get in touch with new reliable partners.

At the level of positional embeddedness, research within the strategic management literature has studied the different relationships between alliances, positional embeddedness and innovation (Ahuja, 2000a, 2000b; Baum et al., 2000; Kraatz, 1998; Powell et al., 1999; Shan et al., 1994; Stuart, 1998, 2000; Walker et al., 1997), although most of these studies focus on singular causal relationships (Grodal, 2004) while using a specific dataset.

Following suggestions by Grodal (2004), we therefore empirically analyzed the multiple causal relationships between R\&D partnership formation, positional embeddedness and innovative performance using one and the same dataset. We made use of one and the same dataset in order to be able to link the different studies of previous literature with each other and to be able to draw some conclusions from the body of studies as a whole. We first investigated the effect of the number of new R\&D partnerships formed by a company on its innovative performance. Next, we looked at the effect of a company's innovative performance on its formation of new R\&D partnerships. Another point of interest was the effect of a company's positional embeddedness on its innovative activities and on its formation of new R\&D partnerships. Finally, we investigated the effect of the number of new $R \& D$ partnership formed by a company on its positional embeddedness.

Our statistical analyses confirmed all hypotheses, meaning that $R \& D$ partnership formation, positional embeddedness and innovative performance all have a significant positive effect on each other. Overall, it can be concluded that with respect to the behavior of firms, positional embeddedness plays a role in explaining the formation of new R\&D partnerships. Furthermore, with respect to the performance of firms, we found empirical evidence that indicates that positional embeddedness plays a role in explaining a firm's innovative activities.

Not only does the formation of R\&D partnerships increase innovation, which increases $R \& D$ partnership formation again, but $R \& D$ partnership formation also provides more central connectedness within the alliance network, which on its turn increases $R \& D$ partnership formation as well as innovation. Our findings support the so-called Matthew effect, referring to a situation in which already innovative 
companies constantly increase their innovative performance even further by increasing their level of R\&D partnership formation and positional embeddedness.

\subsubsection{The role of relational embeddedness}

At the level of relational embeddedness, research in strategic management has focused on the role that tie strength plays in explaining innovation. One part of the strategic management literature expects that gaining access to diverse local networks and to non-redundant information provided by weak network ties should also facilitate a more diverse information gathering process. Exposure to different approaches and new perspectives may stimulate a company to make changes in routines and experiment with new opportunities that change its capabilities and increase its technological performance (Dodgson, 1993; Feldman and Audretsch, 1999; Granovetter, 1982; Hagedoorn and Duysters, 2002; Kogut, 2000; Liebeskind et al., 1996; March, 1991; Ruef, 2002; Schilling and Steensma, 2001).

Others suggest that strong network ties of companies generate better results than weak ties. Strong ties may be beneficial by providing a strong social environment and mutual support for network players (Krackhardt, 1992), by creating relational trust and reciprocity in information exchange between partners (Larson, 1992) which affects the degree to which companies can share knowledge with, and learn from, their partners (Kale, Singh and Perlmutter, 2000), thereby enabling companies to better adapt to environmental changes because they can learn from their well-connected environment (Kraatz, 1998). Companies can use their strong ties to take advantage of joint learning and knowledge spillovers, while avoiding the duplication of innovative efforts, to improve their technological performance.

Following some suggestions for a more multi-dimensional approach (see for instance McEvily and Zaheer, 1999), we investigated the effect of inter-firm network ties on innovative performance from a multi-dimensional perspective that returns to some basic elements of the original contribution by Granovetter (1973). As a first step towards a more multi-dimensional understanding of the strength of inter-firm network ties, we translated Granovetter's original description of the characteristics of network ties to R\&D partnerships and arrive at a set of parallel indicators.

First, the amount of time invested in a relationship was determined by looking at the length of the history of the partnerships of a company, resulting in the first dimension. Next, the intensity of the network ties of a company was interpreted as the multitude of partnerships of a company, resulting in the second dimension. Third, intimacy and the reciprocity within a relationship were translated into the degree of cooperation through the organizational interaction of partners in terms of the share of the joint ventures of a company in all its partnerships, resulting in the third dimension. Fourth, the similarity of the social circles of partners was captured by their cultural closeness and the similarity of these networks through partnerships with other companies. Given the international context of our study, the degree of cultural 
closeness was expressed in terms of domestic partnership formation and international cultural closeness. Domestic partnership formation denoted the share of domestic partnerships in the total of partnerships of a company, resulting in the fourth dimension. International cultural closeness characterized the degree to which a company has established partnerships with companies from countries that are culturally similar, or not, resulting in the fifth dimension. Finally, similarity of the networks in which two or more companies find themselves was expressed in terms of their structural equivalence which indicates the degree of interaction with companies that operate in similar networks, resulting in the sixth dimension.

As suggested by other research that considers the strength of network ties in a multi-dimensional setting (for instance Marsden and Campbell, 1984), we applied a factor analysis to indicate the degree of coherence between the six different dimensions of tie strength. With the outcome of this partial analysis, we constructed an index of the strength of different ties that preserved the multi-dimensional character of the strength of network ties.

The performed factor analysis resulted into three different factors, the factor extent (including dimension one and two), the factor depth (including dimension three and six) and the factor cultural closeness (including dimension four and five). Our results indicated that in line with the strong ties perspective, the factor depth (referring to the degree of cooperation by means of joint ventures and the similarity of networks) and the factor extent (referring to the length of partnerships and the multitude of partnerships between companies) both have a positive effect on the innovative performance of companies, although the factor depth appears to have the highest impact. Interestingly, the factor cultural closeness (referring to the degree of domestic partnership formation and the international cultural closeness) has a negative effect on the innovative performance of companies, thereby supporting the weak ties perspective.

Overall, it can be concluded that with respect to the performance of firms, we found empirical evidence that indicates that relational embeddedness plays a role in explaining the innovative activities of firms. At the level of relational embeddedness, when we consider the effect of the strength of inter-firm network ties in R\&D partnerships, some aspects of strong ties do indeed also improve the technological performance of companies: network ties in inter-firm R\&D partnerships improve the technological performance of companies in high-tech industries through the actual strength of their depth-related dimensions and their extent-related dimensions. Although our finding on the relevance of weak, internationally distant, tie characteristics seems surprising, it does indicate the importance of internationally diverse knowledge sourcing in high-tech industries. Companies participating in international R\&D partnerships with companies that are culturally distant seem to have to engage in inter-organizational learning as they are confronted with new ideas from a variety of international markets and culturally different perspectives. Companies that use this diversity in external, international resources through joint innovative activities 
realize a higher technological performance than companies that participate in $R \& D$ partnerships with domestic companies or companies that are culturally close.

In conclusion, firms should be aware of the role of environmental embeddedness: a firm's choice of governance structure in case of entering new international R\&D partnerships is dependent upon differences in intellectual property rights regimes (at the macro level) and the level of technological change of the industry (at the meso level) in which they are active. Furthermore, for firms that want to increase their innovative performance it is important to realize that their choice of governance is not only dependent upon the environmental embeddedness of the firm, but, on its turn, the choice of governance influences a dimension of tie strength, namely the degree of cooperation, i.e. environmental embeddedness influences relational embeddedness. When considering relational embeddedness, the formation of strong ties, through the "extent" of partnerships (in terms of length and multitude of partnerships) and the "depth" of partnerships (in terms of the degree of cooperation and the similarity of network ties) do improve the innovative performance of firms. However, the formation of weak ties, in terms of international distance, facilitates diverse knowledge sourcing and organizational learning, thereby also enhancing innovative activities. In other words, R\&D network ties that are characterized by a combination of well-embedded ties, with solid, reciprocal, dense, and long-term trustworthy relationships, within a setting of international and culturally diverse interfirm R\&D partnerships seems to be beneficial for the innovative performance of companies. So, allying with internationally more distant firms influences the choice of governance at the macro level of embeddedness, while at the same time it influences the formation of weak ties at the level of relational embeddedness. Furthermore, in particular the formation of R\&D partnerships with new partners will increase a firm's positional embeddedness, which, on its own turn, will further enable the formation of new R\&D partnerships as well as innovative activities. Hence, when making any strategic decisions regarding the partners with whom they might cooperate, firms should take a joint consideration of the different levels of social embeddedness into account.

\subsection{Methodological, empirical, theoretical and managerial implications}

\subsubsection{Methodological and empirical implications}

From a methodological and empirical point of view, this thesis provides two interesting insights. First, from an empirical point of view, previous literature thus far, has analyzed the various relationships between R\&D partnership formation, positional embeddedness and innovation by treating them "in pairs". Furthermore, the different studies investigating these various relationships all make use of a "specific" dataset. These datasets differ from each other, thereby making it difficult to get an overview of how the various relationships relate and complement each other. 
Therefore, we decided in Chapter 4 to establish an integral understanding of the relationships between $\mathrm{R} \& \mathrm{D}$ partnership formation, positional embeddedness and innovation by investigating the multi-causal relationships and the resulting feedback loops between R\&D partnership formation, positional embeddedness and innovative performance of companies using one and the same dataset. We found that the formation of R\&D partnerships increases innovation, which increases $R \& D$ partnership formation again. Furthermore, R\&D partnership formation also provides more central connectedness within the alliance network, which on its turn increases R\&D partnership formation as well as innovation. So the various relationships between R\&D partnership formation, positional embeddedness and innovative performance as investigated by the different studies indeed hold when analyzing them on one and the same dataset, thereby having some important empirical implications.

Second, from a methodological point of view, literature on the effect of interorganizational network strength has a long history of struggling with the measurement of the strength of network ties. Most of the relevant studies use only one indicator of the strength of network ties, very often a binary measurement, nearly always in a domestic setting. It should not come as a surprise that the empirical literature on the effect of the strength of inter-firm network ties generates rather conflicting insights. In a complex international environment with a multitude of inter-firm relationships through a variety of organizational forms, the notion of a multi-dimensional understanding of the strength of network ties appears more adequate to capture this complexity than a simple one-dimensional measurement that seems merely born out of convenience.

Therefore, we decided in Chapter 5 to establish a better understanding of tie strength of firms by performing a multi-dimensional analysis of tie strength. Based upon the original contribution by Granovetter (1973), we identified six dimensions of tie strength: length, multitude, degree of cooperation, similarity of networks, international cultural closeness and domestic partnership formation. As suggested by other research that focuses on tie strength in a multi-dimensional setting (Marsden and Campbell, 1984), we applied a factor analysis to indicate the degree of coherence between the six different dimensions of tie strength. We found that the performed factor analysis resulted into three different factors: the factor extent (including the dimensions length and multitude), the factor depth (including the dimensions degree of cooperation and similarity of networks), and the factor cultural closeness (including the dimensions international cultural closeness and domestic partnership formation). These findings have some important implications for future research, which will be discussed in the next sections.

\subsubsection{Theoretical implications}

From a theoretical point of view, this thesis provides several interesting insights. First, as already has been said, previous literature thus far, has analyzed the various 
relationships between $\mathrm{R} \& \mathrm{D}$ partnership formation, positional embeddedness and innovation by treating them "in pairs" and by using "specific" datasets that differ from each other, thereby making it difficult to get an overview of how the various relationships relate and complement each other.

Therefore, we decided in Chapter 4 to establish an integral understanding of the relationships between R\&D partnership formation, positional embeddedness and innovation. In order to be able to "link" the different studies with each other and to be able to draw some conclusions from the body of studies as a whole, we investigated the multi-causal relationships and the resulting feedback loops between R\&D partnership formation, positional embeddedness and innovative performance of companies using one and the same dataset. Besides empirical implications, our findings also have some important theoretical implications, since we found that already innovative companies constantly increase their innovative performance even further by increasing their level of R\&D partnership formation and positional embeddedness. These findings do indeed suggest that there exists "one dynamic alliance-innovation model" (Grodal, 2004).

Second, based upon the conflicting insights by the empirical literature with respect to the effect of tie strength on innovative performance, we decided in Chapter 5 to establish a better understanding of tie strength of firms. Our findings have some important implications for future research, since we found that a network should perhaps consist of both strong and weak ties to generate benefits to participants (Burt, 1992; Granovetter, 1973; Jack, 2005). These findings suggest that a multi-dimensional understanding of the strength of network ties does not conform to a 'probably linear' combination of the different dimensions of tie-strength, as stated in Granovetter (1973). In other words, it is not so much a balance in a portfolio of strong and weak ties but much more a combination of both strong and weak characteristics within individual network ties (in terms of their extent, depth, and cultural closeness) that create benefits to companies.

Finally, different levels of social embeddedness play a role in explaining the behavior of firms in terms of their choice of governance and their propensity to enter into new R\&D partnerships as well as in explaining the performance of firms in terms of innovative activities. Therefore, we decided to use a multi-level approach of a firm's social embeddedness by making a distinction between environmental embeddedness (macro and meso level), positional embeddedness and relational embeddedness. Our findings showed that different levels of a firm's social embeddedness contribute to its choice of governance, its formation of new R\&D partnerships and its innovative activities. It seems that firms should take a joint consideration of the different levels of their social embeddedness into account when making any strategic decisions regarding the partners with whom they might cooperate. 


\subsubsection{Managerial implications}

Appropriating innovation value by making strategic decisions regarding the partners with whom to cooperate is possible as long as managers understand that they have to jointly consider how the different levels of social embeddedness can strengthen their innovative performance. This thesis provides managers with a guidance by addressing several important characteristics of social embeddedness and R\&D partnerships formation that have a positive impact on a firm's innovative performance.

With respect to environmental embeddedness, managers that want to increase the innovative performance of their firms should be aware of the fact that the choice of governance structure in case of entering new international R\&D partnerships is dependent upon differences in intellectual property rights regimes (at the macro level) and the level of technological change of the industry (at the meso level) in which the firm is active. The decision with respect to the choice of governance on its turn influences relational embeddedness by influencing the degree of cooperation dimension of tie strength, thereby affecting innovative performance.

With respect to relational embeddedness, managers should be aware that the formation of strong ties, through the "extent" of partnerships (in terms of length and multitude of partnerships) and the "depth" of partnerships (in terms of the degree of cooperation and the similarity of network ties) do improve the innovative performance of firms. However, the formation of weak ties, in terms of international distance, facilitates diverse knowledge sourcing and organizational learning, thereby also enhancing innovative activities. Therefore, managers should combine strong and weak ties in order to enhance the innovative activities of their firm.

With respect to positional embeddedness, in particular the formation of $R \& D$ partnerships with new partners will increase a firm's positional embeddedness, which, on its turn, will further enable the formation of new R\&D partnerships as well as innovative activities. In order to understand the relationships between $R \& D$ partnership formation, positional embeddedness and innovative performance, it is important for managers to be aware of the vicious cycle as discussed above. One of the implications is that firms with a rich history of prior alliances are likely to move to a more central position within their network and increase their innovative capabilities, thereby increasing the likelihood of becoming attractive partners for engaging into new alliances. Meanwhile, firms that do not participate that much into inter-firm partnerships may never be able to increase their innovative capabilities and may even never be able to get themselves to enter into a new alliance. Managers could choose to anticipate such concerns about their participation in alliance networks by proactively initiate inter-firm contacts (preferable with central firms) in order to enhance their innovative capabilities and enable the further development of new alliances (see also Gulati, 1999). Finally, managers should be aware that the different levels of the social embeddedness of their firm are intertwined. When making any strategic decisions regarding the partners with whom to cooperate, managers should take a joint consideration of the different levels of embeddedness into account. 


\subsection{Limitations and suggestions for future research}

Limitations of each of the studies have been discussed in detail at the end of each chapter. Therefore, we will only discuss those limitations that cover all chapters and provide some general directions for future research.

A first limitation of our study is the fact that we analyzed positional and relational embeddedness within the context of $R \& D$ partnerships in high-tech sectors. R\&D partnerships within high-tech sectors (pharmaceuticals including biotech, telecom, computers and semiconductors) were selected as the primary context of our analysis for several reasons. First, R\&D partnerships play in particular an important role in high-tech industries where learning and flexibility are important aspects of the competitive landscape (Ciborra, 1991; Dussauge and Garrette, 1999; Eisenhardt and Schoonhoven, 1986; Gomes-Casseres, 1996; Harrigan and Newman, 1990; Oster, 1992). Next, many R\&D partnerships are concentrated in a limited number of hightech industries (Dussauge and Garrette, 1999; Hagedoorn and Schakenraad, 1993; Link and Bauer, 1989; Mytelka, 1991). Finally, in environments in which technological innovation and the need for technological breadth is essential, firms will be more likely to form $\mathrm{R} \& \mathrm{D}$ partnerships in order to acquire new innovation capabilities. Future research, however, could extend this study by examining the relationships between social embeddedness, partnership formation and innovation using a wider range of inter-firm partnerships that cover marketing or production and supply within a broader range of sectors (including medium- and low-tech sectors).

A second limitation of our study is the fact that we focused our analysis on intellectual property right protection and innovative performance in terms of patent rights protection (based upon five major categories of patent rights protection by Ginarte and Park, 1997) and patents (retrieved from the USPTO database) respectively. Admittedly, intellectual property rights protection refers to a wider group of intellectual properties than just patents. A reason for focusing on patent rights protection is that the international differences in the efficiency of patent protection, the broadness of patent protection and the actual enforcement of patent laws (Ginarte and Park, 1997) do indicate a general intellectual property rights protection climate in a country (Marron and Steel, 2000; Ostergard, 2000). Apparently, companies do realize that in that context international $\mathrm{R} \& \mathrm{D}$ partnerships can create serious appropriability hazards unless the necessary precautions are taken (Oxley, 1997; Teece, 1986).

In addition, there are several reasons for using USPTO patents as a measure for innovative performance. First of all, patents are an important measure of innovation output because they are directly related to inventiveness, they represent an externally validated measure of technological novelty, and they confer property rights on the assignee and therefore have economic significance (Griliches, 1990; Kamien and Schwartz, 1982; Scherer and Ross, 1990). Next, research by Hagedoorn and Cloodt (2003) indicates that, in high-tech sectors such as those studied in this thesis, counts of patents are adequate indicators of the overall technological performance of companies. 
There exist several data collections with respect to intellectual property. The most important data collections are the ones from the United States Patent and Trademark Office (USPTO), the European Patent Office (EPO), the Japan Patent Office (JPO), and the data collections hosted by the World Intellectual Property Organization (WIPO). In our study, we have chosen for using patents filed at the USPTO because the USA is the largest technology marketplace in the world, and it has become routine for non-US firms to patent in the USA (Albert, Avery, Narin and McAllister, 1991).

Future research could focus on other measures of intellectual property right protection like copyrights and trademarks. With respect to measures for innovation, future research could, instead of patents, use other measures for innovation from different datasets, like for instance R\&D expenditures, new product announcements or patent citations. Furthermore, future research could make a distinction between incremental innovations, that allow improved performance and benefits without changing consumer patterns or behavior, and radical innovations, resulting in previously unknown products that establish new consumption patterns and behavioral changes, thereby shaping the future of industries and altering the position of companies.

A third limitation of our research is the fact that the study in Chapter 4 was a first attempt to analyze the relationships between R\&D partnership formation, positional embeddedness and innovative performance using multi-causal relationships with the use of one and the same dataset. Future research could extend the current study by using these multi-causal relationships in order to find support for the idea of the existence of "one dynamic alliance-innovation model" (as suggested by Grodal, 2004), which shows a co-evolution of R\&D alliance formation, positional embeddedness and innovation within an alliance network context. A company's network position within an alliance network in particular, and the structure of the alliance network itself in general, are sensitive for changes. It is these structural changes that seem to raise the most fundamental strategic problems for companies in competition (see also Porter, 1981). Instead of using separate analyses as in the current study, future research could analyze the different relationships within one model, thereby revealing the consequences of the systemic dynamics of the model.

Finally, we stress the importance of understanding the complexity that surrounds a firm's social embeddedness. When making any strategic decisions based upon our conclusions with respect to the effects of the different levels of social embeddedness on R\&D partnership formation, innovative performance, and vice versa, firms should take into account a joint consideration of the different levels of embeddedness instead of treating them in isolation. When comparing the results of our different studies, it becomes clear that there exist interaction effects between different levels of social embeddedness. Hagedoorn (2006) discusses the complex interaction effects between the different levels of a firm's social embeddedness, by suggesting the basic argument that different levels of embeddedness exercise a multiplicative, interacting effect on future joint partnering. This implies that country-characteristics 
(at the macro level of environmental embeddedness) and patterns of industrial interfirm partnership formation (at the meso level of environmental embeddedness), as well as the specifics of the partnering history of companies (the level of positional and relational embeddedness) jointly affect their future partnership formation.

According to Hagedoorn (2006), an important argument for the relevance of a "cross-level understanding of embeddedness" is that many firms are engaging into partnerships through a variety of partners from different (sub)sectors, possible from different countries, that each have different partnering histories. This perspective gives greater consideration to the multi-dimensional nature of R\&D partnerships. Furthermore, Hagedoorn and Frankort (2006) and Uzzi (1997) stress the fact that increasing numbers of inter-firm partnerships at different levels of social embeddedness can generate a negative effect of embeddedness that can be characterized as the gloomy side of embeddedness through over-embeddedness, i.e. a possible decreasing propensity to form partnerships. Future research could extend our study by incorporating the interaction effects between the different levels of social embeddedness when analyzing partnerships and innovation. According to Hagedoorn and Frankort (2006), under conditions of increasing social embeddedness, companies could eventually face decreasing opportunities for new partnership formation through over-embeddedness. In other words, there possibly is a gloomy side to embeddedness due to the over-entrenched nature of well-embedded inter-firm partnerships. They conclude that in particular the interaction between over-embeddedness at the relational level and over-embeddedness at the positional level could be a major cause of overembeddedness. Future research could consider the effect of over-embeddedness on partnership formation as well as on innovative performance through the interaction of different levels of over-embeddedness. 


\section{APPENDIX A}

\section{The MERIT Cooperative Agreements and Technology Indicators (CATI) Database}

The MERIT-CATI database is a relational database which contains separate data files that can be linked to each other or to other databases and provide both disaggregated and combined information from several files. For the period 1960-2003, information on around 12.000 technology-related inter-firm partnerships in various sectors, ranging from high technology sectors to low technology sectors, has been collected.

Systematic collection of inter-firm partnerships started in 1987. Many sources from earlier years are consulted to establish a retrospective view. In order to collect information on inter-firm partnerships various sources are consulted: newspaper and journal articles, books dealing with the subject, and in particular specialized journals which report on business events. Company annual reports, the financial times industrial companies yearbooks, and Dun and Bradstreet's "who owns whom" provide information about dissolved equity ventures and investments, as well as ventures that were not registered when surveying partnerships. This method of information gathering which one can refer to as "literature-based alliance counting" has its drawbacks and limitations due to the lack of publicity for certain arrangements, low profile of certain groups of companies and fields of technology. Despite these shortcomings, which are largely unsolvable, this database is able to produce a clear picture of the joint efforts of many companies. This enables researchers to perform empirical research which goes beyond case studies.

The database contains information on each agreement and some information on companies participating in these agreements. The first entity is the inter-firm cooperative agreement. Cooperative agreements are defined as common interests between independent (industrial) partners who are not connected through (majority) ownership. In the MERIT-CATI database only those inter-firm agreements are being collected that contain some arrangements for transferring technology or joint research. Joint research pacts and second-source are clear-cut examples. Information is also collected on joint ventures in which new technology is received from at least one of the partners, or joint ventures having some $R \& D$ program. Other types of agreements such as production and marketing partnerships are not included. In other words, this material is primarily related to $\mathrm{R} \& \mathrm{D}$ collaboration and technology cooperation, i.e. those agreements for which a combined innovative activity or an exchange of technology is at least part of the agreement. A large body of prior empirical research on R\&D partnerships is based on the MERIT-CATI database (see for instance, Duysters and Hagedoorn, 1996, 2000, 2002; Gulati, 1995; Gulati and Singh, 1998; Hagedoorn, 1993; Hagedoorn and Schakenraad, 1994). 


\section{APPENDIX B}

\section{The United States Patent and Trademark Office (USPTO) Database}

The USPTO is an intellectual property organization of the US Department \& Commerce who registers patent applications from all over the world. The database we used is the USPTO (PATSIC-CONAME) database, which includes full-text information for all patents applied for in the USA. The attributes included in this database are: patent number, country, name of the company, patent application submission date, date patent was granted, patent classes, patent assignee code, primary classification number and the individual SIC codes for the primary classifications.

US patent data are used for both US and non-US companies. Although this US data could imply a bias in favor of US companies and against non-US companies, it is mentioned in the innovation literature that non-US companies often need to file patents in the US, given the importance of the US market, the "real" patent protection offered by US authorities, and the level of technological sophistication of the US market (Patel and Pavitt, 1991).

Patent indicators have been used in many prior studies, as indicators of innovative performance (see for instance, Ahuja, 2000a, 2000b; Hagedoorn and Duysters, 2002b; Hall, Jaffe and Trajtenberg, 2000), technological knowledge base (see for instance, Jaffe and Trajtenberg, 2002), and knowledge flows (see for instance, Mowery et al., 1996). 


\section{REFERENCES}

A

Adler, P.S. and S-W. Kwon, 2002, Social capital: prospects for a new concept, Academy of Management review, 27, pp. 17-40.

Ahuja, G., 2000a, Collaboration networks, structural holes and innovation: a longitudinal study, Administrative Science Quarterly, 45, pp. 425-455.

Ahuja, G., 2000b, The duality of collaboration: inducements and opportunities in the formation of interfirm linkages, Strategic Management Journal, 21, pp. 317343.

Ahuja G. and R. Katila, 2001, Technological acquisitions and the innovation performance of acquiring firms: a longitudinal study, Strategic Management Journal, 22, pp. 197-220.

Albert, M.B., Avery, D., Narin, F. and P. McAllister, 1991, Direct validation of citation counts as indicators of industrially important patents, Research Policy, 20, pp. 251-259.

Allen, P.M., 1988, Evolution, innovation and economics, in: Dosi, G., Freeman, C., Nelson, R., Silverberg, G. and L. Soete (eds.), Technical change and economic theory, London, Pinter, pp. 95-120.

Auster, E.R., 1987, International corporate linkages: dynamic forms in changing environments, Columbia Journal of World Business, 22, pp. 3-13.

B

Balakrishnan, S. and M.P. Koza, 1993, Information asymmetry, adverse selection and joint ventures: theory and evidence, Journal of Economic Behavior and Organization, 20, pp. 99-117.

Barkema, H., Shenkar, O., Vermeulen, F. and J. Bell, 1997, Working abroad, working with others: how firms learn to operate international joint ventures, Academy of Management Journal, 40, pp. 426-442.

Barkema, H.G. and F. Vermeulen, 1998, International expansion through start-up or acquisition: a learning perspective, Academy of Management Journal, 41, pp. 726.

Baum, J.A.C., Calabrese, T. and B.S. Silverman, 2000, Don't go it alone: alliance network composition and startups' performance in Canadian biotechnology, Strategic Management Journal, 21, pp. 267-294.

Belderbos, R., Carree, M. and B. Lokshin, 2004, Cooperative R\&D and firm performance, Research Policy, 33, pp. 1477-1492.

Bell, G.G., 2005, Research notes and commentaries: clusters, networks, and firm innovativeness, Strategic Management Journal, 26, pp. 287-295.

Berg, S.V, J. Duncan and P. Friedman, 1982, Joint venture strategies and corporate innovation, Oelgeschlager, Cambridge (MA). 
Borgatti, S.P., Everett, M.G. and L.C. Freeman, 2002, Ucinet for Windows version 6.29: Software for social network analysis, Harvard (MA): Analytic Technologies.

Bound, J., Cummins, C., Griliches, Z., Hall, B.H. and A. Jaffe, 1984, Who does R\&D and who patents?, in: Griliches, Z. (ed.), R\&D, patents, and productivity, University of Chicago Press, Chicago, pp. 21-54.

Brass, D.J., Butterfield, D.D. and B.C. Skaggs, 1998, Relationships and unethical behavior: a social network perspective, Academy of Management Review, 23, pp. 14-31.

Bruederl, J. and P. Preisendoerfer, 1998, Network support and the success of newly founded businesses, Small Business Economics, 10, pp. 213-225.

Buckley P.J. and M. Casson, 2002, A theory of cooperation in international business, in: Contractor, F.J. and P. Lorange (eds.), Cooperative strategies and alliances in international business, Elsevier Science, Amsterdam, pp. 31-53.

Burt, R.S., 1992, Structural holes: the social structure of competition, Harvard University Press, Cambridge (MA).

Buskens, V. and W. Raub, 2002, Embedded trust: control and learning, Advances in group processes, 19, pp. 167-202.

C

Cameron, A.C. and P.K. Trivedi, 1986, Econometric models based on count data: comparisons and applications of some estimators and tests, Journal of Applied Econometrics, 1, pp. 29-53.

Chesbrough, H. and D. Teece, 1996, When is virtual virtuous: organizing for innovation, Harvard Business Review, January-February, pp. 65-74.

Chesnais, F., 1988, Technical cooperation agreements between firms, STI Review, 4, pp. 51-120.

Chi T. and T.W. Roehl, 1997, The structure of inter-firm exchanges in business knowhow: evidence from international collaborative ventures, Managerial and Decision Economics, 18, pp. 279-294.

Chung, S., Singh, H. and K. Lee, 2000, Complementarity, status similarity and social capital as drivers of alliance formation, Strategic Management Journal, 21, pp. $1-22$.

Ciborra, C., 1991, Alliances as learning experiments: cooperation, competition and change in high-tech industries, in: Mytelka, L.K. (ed.), Strategic partnerships and the world economy, Pinter, London, pp. 51-77.

Cincera, M., 1997, Patents, R\&D, and technological spillovers at the firm level: some evidence from econometric count models for panel data, Journal of Applied Econometrics, 12, pp. 265-280.

Cohen, W.M. and R.C. Levin, 1989, Empirical studies of innovation and market structure, in: Schmalensee, R. and R. Willig (eds.), Handbook of industrial organization, Elsevier, Amsterdam, 2, pp. 1059-1107. 
Cohen, W.M. and D.A. Levinthal, 1989, Innovation and learning: the two faces of R\&D, The Economic Journal, 99, pp. 569-596.

Cohen, W.M. and D.A. Levinthal, 1990, Absorptive capacity: a new perspective on learning and innovation, Administrative Science Quarterly, 35, pp. 128-152.

Cohen, W.M., Nelson R.R. and J. P. Walsh, 2000, Protecting their intellectual assets: appropriability conditions and why U.S. manufacturing firms patent (or not), Cambridge (MA), National Bureau of Economic Research, working paper 7552.

Coleman, J.S., 1990, Rational action, social networks, and the emergence of norms, in: Calhoun, C., Meyer, M.W. and W.R. Scott (eds.), Structures of power and constraint, The Cambridge University Press, New York, pp. 91-112.

Conner, K. and C.K. Prahalad, 1996, A resource-based theory of the firm: knowledge versus opportunism, Organization Science, 7, pp. 477-501.

Contractor, F.J., Kim, C. and S, Beldona, 2002, Interfirm learning in alliances and technology networks: an empirical study in the global pharmaceutical and chemical industries, in: Contractor, F.J. and P. Lorange (eds.), Cooperative strategies in international business, Elsevier Science, Amsterdam, pp. 493-516.

Contractor, F.J., and P. Lorange, 1988, Why should firms cooperate? The strategy and economics basis for cooperative ventures, in: Contractor, F.J. and P. Lorange (eds.), Cooperative strategies in international business, Lexington Books, Lexington (MA), pp. 3-30.

Contractor, F.J. and P. Lorange (eds.), 2002, Cooperative strategies and alliances in international business, Elsevier Science, Amsterdam, pp. 493-516.

D

Dacin, M.T., Ventresca, M.J. and B.D. Beal, 1999, The embeddedness of organizations: dialogue and directions, Journal of Management, 25, pp. 317356.

Das, S., Sen, P.K. and S. Sengupta, 1998, Impact of strategic alliances on firm valuation, Academy of Management Journal, 41, pp. 27-41.

De Man, A.-P., 2004, The network economy: strategy, structure and management, Edward Elgar, Northampton (MA), USA.

De Man, A.-P. and G. Duysters, 2005, Collaboration and innovation: a review of the effects of mergers, acquisitions and alliances on innovation, Technovation, 25, pp. 1377-1387.

De Woot, P., 1990, High technology Europe: strategic issues for global competitiveness, Blackwell, Oxford.

Dodgson, M., 1993, Organizational learning: a review of some literatures, Organization Studies, 14, pp. 375-394.

Dunning, J., 1993, Multinational enterprises and the global economy, AddisonWesley, London.

Dussauge, P, and B. Garrette, 1999, Cooperative strategy: competing successfully through strategic alliances, Wiley, Chichester. 
Duysters, G. and J. Hagedoorn, 1996, Internationalization of corporate technology through strategic partnering: an empirical investigation, Research Policy, 25, pp. 1-12.

Duysters, G. and J. Hagedoorn, 2000, International technology collaboration: implications for NIEs, in: Kim, L. and R.R. Nelson (eds.), Technology, learning \& innovation: experiences of newly industrializing economies, The Cambridge University Press, Cambridge, pp. 193-215.

Dyer, J. and H. Singh, 1998, The relational view: cooperative strategy and sources of inter-organizational competitive advantage, Academy of Management Review, 23 , pp. 660-679.

E

Eisenhardt, K.M. and J.A. Martin, 2000, Dynamic capabilities: what are they?, Strategic Management Journal, 21, pp. 1105-1121.

Eisenhardt, K.M. and C.B. Schoonhoven, 1996, Resource-based view of strategic alliance formation: strategic and social effects in entrepreneurial firms, Organization Science, 7, pp. 136-150.

F

Feldman, M.P. and D.B. Audretsch, 1999, Innovation in cities: science-based diversity, specialization, and localized competition, European Economic Review, 43, pp. 409-429.

Ferrantino, M., 1993, The effect of intellectual property rights on international trade and investment, Weltwirtschaftliches Archiv, 129, pp. 300-331.

Fink, C. and C.A. Primo Braga, 1999, How stronger protection of intellectual property rights affects international trade flows, Policy research working paper 2051, The World Bank, Washington DC.

Freeman, L.C., 1979, Centrality in social networks: conceptual clarification, Social Networks, 1, pp. 215-239.

Freeman, C. and J. Hagedoorn, 1994, Catching up or falling behind: patterns in international interfirm technology partnering, World Development, 22, pp. 771780.

Freeman, C. and L. Soete, 1997, The economics of industrial innovation, Pinter, London.

\section{G}

George, G., Zahra, S.A. and D.R. Wood, 2002, The effects of business-university alliances on innovative output and financial performance: a study of publicly traded biotechnology companies, Journal of Business Venturing, 17, pp. 577609.

Ghoshal, S., 1987, Global strategy: an organizing framework, Strategic Management Journal, 8, pp. 425-440. 
Ginarte, J.C. and W.G. Park, 1997, Determinants of patent rights: a cross-national study, Research Policy, 26, pp. 283-301.

Godoe, H., 2000, Innovation regimes, R\&D and radical innovations in telecommunications, Research Policy, 29, pp. 1033-1046.

Gomes-Casseres, B., 1996, The alliance revolution: the new shape of business rivalry, Harvard University Press, Cambridge (MA).

Gourieroux, C., Montfort, A. and A. Trognon, 1984a, Psuedo maximum likelihood methods: theory, Econometrica, 52, pp. 681-700.

Gourieroux, C., Montfort, A. and A. Trognon, 1984b, Psuedo maximum likelihood methods: applications to Poisson models, Econometrica, 52, pp. 701-720.

Granovetter, M., 1973, The strength of weak ties, American Journal of Sociology, 78, pp. $1360-1380$.

Granovetter, M.S., 1982, The strength of weak ties: a network theory revisited, in: Marsden, P.V. and N. Lin (eds.), Social structure and network analysis, Sage, Beverly Hills (CA), pp. 105-130.

Granovetter, M., 1985, Economic actions and social structure: the problem of embeddedness. American Journal of Sociology, 91, pp. 481-510.

Granovetter, M., 1992, Economic action and social structure: the problem of embeddedness, in: Granovetter, M. and R. Swedberg (eds.), The sociology of economic life, Westview Press, Boulder (CO), pp. 53-81.

Grant, R.M., 1996, Toward a knowledge-based theory of the firm, Strategic Management Journal, 17 (Winter Special Issue), pp. 109-122.

Griliches, Z., 1984, Market value, $R \& D$ and patents, University of Chicago Press, Chicago.

Griliches, Z., 1990, Patent statistics as economic indicators: a survey, Journal of Economic Literature, 28, pp. 1661-1707.

Griliches, Z., 1998, $R \& D$ and productivity: the econometric evidence, University of Chicago Press, Chicago.

Grodal, S., 2004, Towards a dynamic model of networks and innovation, paper presented at the DRUID Summer Conference 2004.

Gulati, R., 1995, Social structure and alliance formation patterns: a longitudinal analysis, Administrative Science Quarterly, 40, pp. 619-652.

Gulati, R., 1997, Which firms enter into alliances? An empirical assessment of financial and social capital explanations, working paper, J.L. Kellogg Graduate School of Management, Northwestern University.

Gulati, R., 1998, Alliances and networks, Strategic Management Journal, 19, pp. 293317.

Gulati, R., 1999, Network location and learning: the influence of network resources and firm capabilities on alliance formation, Strategic Management Journal, 20, pp. 397-420.

Gulati, R. and M. Gargiulo, 1999, Where do interorganizational networks come from? American Journal of Sociology, 104, pp. 1439-1493. 
Gulati, R. and H. Singh, 1998, The architecture of cooperation: managing coordination costs and appropriation concerns in strategic alliances. Administrative Science Quarterly, 43, pp. 781-814.

Gulati, R., Nohria, N. and A. Zaheer, 2000, Strategic networks, Strategic Management Journal, 21, pp. 203-215.

$\mathbf{H}$

Hagedoorn, J., 1993, Understanding the rationale of strategic technology partnering: inter-organizational modes of cooperation and sectoral differences, Strategic Management Journal, 14, pp. 371-385.

Hagedoorn, J., 1996, Trends and patterns in strategic technology partnering since the early seventies, Review of Industrial Organization, 11, pp. 601-616.

Hagedoorn, J., 2002, Inter-firm R\&D partnerships: an overview of major trends and patterns since 1960, Research Policy, 31, pp. 477-492.

Hagedoorn, J., 2006, Understanding the cross-level embeddedness of inter-firm partnership formation, Academy of Management Review, 31, pp. 670-680.

Hagedoorn, J. and M. Cloodt, 2003, Measuring innovative performance: is there an advantage in using multiple indicators?, Research Policy, 32, pp. 1365-1379.

Hagedoorn, J., Cloodt, D., and H. van Kranenburg, 2005, Intellectual property rights protection and the governance of international R\&D partnerships, Journal of International Business Studies, 36, pp. 175-186.

Hagedoorn, J. and G.M. Duysters, 2002a, Learning in dynamic inter-firm networks the efficacy of multiple contacts, Organization Studies, 23, pp. 525-548.

Hagedoorn, J. and G. Duysters, 2002b, External sources of innovative capabilities: the preference for strategic alliances or mergers and acquisitions, Journal of Management Studies, 39, pp. 167- 188.

Hagedoorn, J. and H. Frankort, 2006, The gloomy side of embeddedness: the effect of over-embeddedness on partnership formation, in: Baum, J.A.C. and T.J. Rowley (eds.), Network Strategy - Advances in Strategic Management, 25, Elsevier.

Hagedoorn, J., Link, A.L., and N. Vonortas, 2000, Research partnerships, Research Policy, 29, pp. 567-586.

Hagedoorn, J. and R. Narula, 1996, Choosing organizational modes of strategic technology partnering: international and sectoral differences, Journal of International Business Studies, 27, pp. 265-284.

Hagedoorn, J., Roijakkers, N. and H. van Kranenburg, 2006, Inter-firm R\&D networks: the importance of strategic network capabilities for high-tech partnership formation, British Journal of Management, 17, pp. 39-53.

Hagedoorn, J. and J. Schakenraad, 1993, A comparison of private and subsidized interfirm linkages in the European IT industry, Journal of Common Market Studies, 31, pp. 373-390.

Hagedoorn, J. and J. Schakenraad, 1994, The effect of strategic technology alliances on company performance, Strategic Management Journal, 15, pp. 291-311.

Hagedoorn, J. and H. van Kranenburg, 2003, Growth patterns in R\&D partnerships: an 
exploratory statistical study, International Journal of Industrial Organization, 21, pp. 517-531.

Hair, J.F., Anderson, R.E., Tatham, R.L. and W.C. Black, 1995, Multivariate data analysis with readings, Prentice-Hall, $4^{\text {th }}$ edition, New Jersey, USA.

Haklisch, C.S., 1986, Technical alliances in the semiconductor industry, Mimeo, New York University.

Haklisch, C.S., 1989, Technical alliances in the semiconductor industry: effects on corporate strategy and R\&D, in: Background Papers for Conference on Changing Global Patterns of Industrial Research and Development, Stockholm, June 20-22.

Hall, B.H., Jaffe, A.B. and M. Trajtenberg, 2000, Market value and patent citations: a first look, http://elsa.berkeley.edu/ bhhall/papers/HallJaffeTrajtenberg_RJEjan 04.pdf.

Hall, B.H., Griliches, Z. and J. Hausman, 1986, Patents and R\&D, is there a lag?, International Economic Review, 27, pp. 265-283.

Hamel, G., 2000, Leading the revolution, Harvard Business School Press, Boston.

Hanneman, R.A., 2001, Introduction to social network methods, Department of Sociology, University of California, Riverside.

Hansen, M.T., 1999, The search-transfer problem: the role of weak ties in sharing knowledge across organization subunits, Administrative Science Quarterly, 44, pp. 82-111.

Harrigan, K.R., 1985, Strategies for joint ventures, Lexington Books, Lexington (MA).

Harrigan, K.R., 1988, Joint ventures and competitive strategy, Strategic Management Journal, 9, pp. 141-158.

Harrigan, K.R. and W.H. Newman, 1990, Bases of interorganization co-operation: propensity, power, persistence, Journal of Management Studies, 27, pp. 417434.

Hausman, J., Hall B.H. and Z. Griliches, 1984, Econometric models for count data with an application to the patents-R\&D relationship, Econometrica, 52, pp. 909938.

Hergert, M., and D. Morris, 1988, Trends in international collaborative agreements, in: Contractor, F.J., and P. Lorange (eds.), Cooperative strategies in international business, Lexington Books, Lexington (MA).

Hite, J.M., 2003, Patterns of multi-dimensionality among embedded network ties: a typology of relational embeddedness in emerging entrepreneurial firms, Strategic Organization, 1, pp. 9-49.

Hite, J.M. and W.S. Hesterly, 2001, The evolution of firm networks: from emergence to early growth of the firm, Strategic Management Journal, 22, pp. 275-286.

Hitt, M.A., Hoskisson, R.E., Johnson R.A. and D.D. Moesel, 1996, The market for corporate control and firm innovation, Academy of Management Journal, 39, pp. 1084-1119.

Hladik, K.J., 1985, International joint ventures, Lexington Books, Lexington (MA). 
Hladik, K.J., 1988, R\&D and international joint ventures, in: Contracor, L. and P. Lorange (eds.), Cooperative strategies in international business, Lexington Books, Lexington (MA), pp. 187-207.

Hoang, H. and B. Antoncic, 2003, Network-based research in entrepreneurship: a critical review, Journal of Business Venturing, 18, pp. 495-527.

Hoang, H. and F.T. Rothaermel, 2005, The effect of general and partner-specific alliance experience on joint R\&D project performance, Academy of Management Journal, 48, pp. 332-345.

Hoecklin, J., 1995, Managing cultural differences: strategies for competitive advantage, Sage Publications, Workingham.

Hofstede, G.H., 1980, Culture's consequences: international differences in workrelated values, Sage Publications, Beverly Hills (CA).

Hoskisson, R.E., and M.A. Hitt, 1994, Downscoping: how to tame the diversified firm, Oxford University Press, Oxford.

\section{$\mathbf{J}$}

Jack, S.L., 2005, The role, use and activation of strong and weak network ties: a qualitative analysis, Journal of Management Studies, 42, pp. 1233-1259.

Jaffe, A. and M. Trajtenberg, 2002, Patents, citations and innovations: a window on the knowledge economy, The MIT press, Cambridge.

Jansen, D., 2004, Networks, social capital and knowledge production, Forschungsinstitut für Öffentliche Verwalting (FÖV) discussion papers, 8.

Jenssen J.I. and H.F. Koenig, 2002, The effect of social networks on resource access and business start-ups, European Planning Studies, 10, pp. 1039-1046.

\section{K}

Kale, P., Singh, H. and H. Perlmutter, 2000, Learning and protection of proprietary assets in strategic alliances: building relational-specific capital, Strategic Management Journal, Special Issue, 21, pp. 217-237.

Kamien, M.I. and N.L. Schwartz, 1982, Market structure and innovation, The Cambridge University Press, Cambridge.

Knoke, D. and R.S. Burt, 1983, Prominence, in: Burt, R.S. and M. Minor (eds.), Applied network analysis: a methodological introduction, Sage, Beverly Hills (CA), pp. 195-222.

Knoke, D. and J.H. Kuklinsky, 1982, Network analysis, Sage Publications, Series: Quantitative Applications in the Social Sciences, Beverly Hills: Sage University Paper 28.

Kogut, B., 1988, Joint ventures: theoretical and empirical perspectives, Strategic Management Journal, 9, pp. 319-332.

Kogut, B., 2000, The network as knowledge: generative rules and the emergence of structure, Strategic Management Journal, 21, pp. 405-425.

Kogut, B., Shan, W. and G. Walker, 1992, The make-or-cooperate decision in the context of an industry network, in: Nohria, N. and R. Eccles (eds.), Networks 
and organizations, Harvard Business School Press, Cambridge (MA), pp. 348365.

Kogut, B. and H. Singh, 1988, The effect of national culture on the choice of entry mode, Journal of International Business Studies, 19, pp. 411-432.

Kogut, B. and U. Zander, 1992, Knowledge of the firm, combinative capabilities, and the replication of technology, Organization Science, 3, pp. 383-397.

Koka, B.R. and J.E. Prescott, 2002, Strategic alliances as social capital: a multidimensional view, Strategic Management Journal, 23, pp. 795-816.

Kraatz, M.S., 1998, Learning by association? Interorganizational; networks and adaptation to environmental change, Academy of Management Journal, 41, pp. 621-643.

Krackhardt, D., 1992, The strength of strong ties: the importance of philos in organization, in: Nohria, N. and R.C. Eccles (eds.), Networks and organizations: structure, form, and action, Harvard Business School Press, Boston (MA), pp. 216-239.

$\mathbf{L}$

Lam, A., 1997, Embedded firms, embedded knowledge: problems of collaboration and knowledge transfer in global cooperative ventures, Organization Studies, 18, pp. 973-996.

Lane, P.J. and M. Lubatkin, 1998, Relative absorptive capacity and interorganizational learning, Strategic Management Journal, 19, pp. 461-477.

Larson, A., 1992, Network dyads in entrepreneurial settings: a study of the governance of exchange processes, Administrative Science Quarterly, 37, pp. 76-104.

Lazega, E., 2000, Teaming up and out? Getting durable cooperation in a collegial organization, European Sociological Review, 16, pp. 245-266.

Lazzarini, S.G., 2005, From alliance networks to multilateral alliances: understanding the organization of multiple-firm linkages in the context of the global airline industry, Working Paper, March 2005.

Lechner, C. and M. Dowling, 2003, Firm networks: external relationships as sources for the growth and competitiveness of entrepreneurial firms, Entrepreneurship and Regional Development, 15, pp. 1-26.

Lee J. and E. Mansfield, 1996, intellectual property protection and US foreign direct investment, Review of Economics and Statistics, 77, pp. 181-186.

Leun-Kwong Wong, P. and P. Ellis, 2002, Social ties and partner identification in Sino-Hong Kong international joint ventures, Journal of International Business Studies, 33, pp. 267-289.

Levitt, T., 1983, The globalization of markets, Harvard Business Review, 61, pp. 92102.

Liebeskind, J., Oliver, A., Zucker, L. and M. Brewer, 1996, Social networks, learning, and flexibility: sourcing scientific knowledge in new biotechnology firms, Organization Science, 7, pp. 428-443. 
Link, A.N. and L.L. Bauer, 1989, Cooperative research in U.S. manufacturing: assessing policy initiatives and corporate strategies, Lexington Books, Lexington (MA).

Lorenzoni, G., and A. Lipparini, 1999, The leveraging of interfirm relationships as a distinctive organizational capability: a longitudinal study, Strategic Management Journal, 20, pp. 317-338.

Lundan S. and J. Hagedoorn, 2001, Alliances, acquisitions and multinational advantage, International Journal of the Economics of Business, 8, pp. 229-242.

M

Mairesse, J. and P. Mohnen, 2005, The importance of R\&D for innovation: a reassessment using French survey data, Journal of Technology Transfer, 30, pp. 183-197.

Mansfield, E., 1986, Patents and innovation: an empirical study, Management Science, 32, pp. 173-181.

March, J., 1991, Exploration and exploitation in organizational learning, Organization Science, 2, pp. 71-87.

Mariti, P. and R.H. Smiley, 1983, Co-operative agreements and the organization of industry, Journal of Industrial Economics, 31, pp. 3437-3451.

Marsden, P. and K. Campbell., 1984, Measuring tie strength, Social Forces, 63, pp. 482-501.

Marron, D.B. and D.G. Steel, 2000, Which countries protect intellectual property? The case of software piracy, Economic Inquiry, 38, pp. 159-174.

McEvily B. and A. Zaheer, 1999, Bridging ties: a source of firm heterogeneity in competitive capabilities, Strategic Management Journal, 20, pp. 1133-1156.

Meagher, K. and M. Rogers, 2004, Network density and R\&D spillovers, Journal of Economic Behavior and Organization, 53, pp. 237-260.

Merton, R.K., 1968, The Matthew effect in science: the reward and communication systems of science are considered, Science, 159, pp. 56-63.

Mille A., 1997, Copyright in the cyberspace era, European Intellectual Property Review, 19, pp. 570-577.

Miller, D., 1996, The embeddedness of corporate strategy: isomorphism vs. differentiation, Advances in Strategic Management, 13, pp. 283-291.

Mody, A., 1993, Learning through alliances, Journal of Economic Behavior and Organization, 20, pp. 151-170.

Mohr, L.B., 1982, Explaining organizational behavior, Jossey-Bass, San Fransisco (CA).

Mowery, D.C., 1983, The relationship between intrafirm and contractual forms of industrial research in American manufacturing, 1900-1940, Explorations in Economic History, 20, pp. 351-374.

Mowery, D.C., 1988, International collaborative ventures in US manufacturing, Ballinger, Cambridge (MA). 
Mowery, D.C., Oxley, J.E., and B.S. Silverman, 1996, Strategic alliances and interfirm knowledge transfer, Strategic Management Journal, 17 (Winter Special Issue), pp. 77-91.

Mowery, D.C., Oxley, J.E., and B.S. Silverman, 1998, Technological overlap and interfirm cooperation: implications for the resource-based view of the firm, Research Policy, 27, pp. 507-523.

Mueller, D.C., 1986, The modern corporation-profits, power, growth and performance, Wheatsheaf Books, Brighton.

Muralidharan R. and A. Phatak, 1999, International R\&D activity of US MNCs: an empirical study with implications for host government policy, Multinational Business Review, 7(2), pp. 97-105.

Mytelka, L.K., 1991, Strategic partnerships and the world economy, Pinter, London.

$\mathbf{N}$

Narula, R., 1996, Forms of international cooperation between corporations, in: Jepma, C. and A. Rhoen (eds.), International trade: a business perspective, Longman, Harlow, pp. 98-122.

Narula, R. and J. Hagedoorn, 1999, Innovating through strategic alliances: moving towards international partnerships and contractual agreements, Technovation, 19, pp. 283-294.

Nelson, R.R., 1990, US technological leadership: where did it come from and where did it go, Research Policy, 79, pp. 119-132.

Nohria, N. and C. Garcia-Pont, 1991, Global strategic linkages and industry structure, Strategic Management Journal, 12, pp. 105-124.

Nonaka, I., 1991, The knowledge creating company, Harvard Business Review, 69, pp. 96-104.

Nonaka, I. and H. Takeuchi, 1995, The knowledge creating company: how Japanese companies create the dynamics of innovation, Oxford University Press.

Nooteboom, B., 1999, Inter-firm alliances: analysis and design, Routledge, London.

$\mathbf{O}$

OECD, 1986, Technical cooperation agreements between firms: some initial data and analysis, OECD, Paris.

OECD, 1992, Technology and the economy, OECD, Paris.

OECD, 1997, Revision of the high technology sector and product classification, OECD, Paris.

Ohmae, K., 1985, TRIAD power, Free Press, New York.

Ohmae, K., 1990, The borderless world, Harper, New York.

Osborn, R.N., and C.C. Baughn, 1990, Forms of interorganizational governance for multinational alliances, Academy of Management Journal, 33, pp. 503-519.

Oster, S.M., 1992, Modern competitive analysis, Oxford University Press, New York.

Ostergard, R.L., 2000, The measurement of intellectual property rights protection, Journal of International Business Studies, 31, pp. 349-360. 
Oxley, J.E., 1997, Appropriability hazards and governance in strategic alliances: a transaction cost approach, Journal of Law, Economics, and Organization, 13, pp. 387-409.

Oxley, J.E., 1999, Institutional environment and the mechanism of governance: the impact of intellectual property protection on the structure of inter-firm alliances, Journal of Economic Behavior and Organization, 38, pp. 283-309.

$\mathbf{P}$

Pakes, A. and Z. Griliches, 1984, Patents and R\&D at the firm level; a first look, in: Griliches, Z. (ed), R\&D, patents and productivity, The University of Chicago Press, Chicago, pp. 55-72.

Patel, P. and K. Pavitt, 1991, Large firms in the production of the world's technology: an important case of non-globalization, Journal of International Business Studies, 22, pp. 1-21.

Pennings, J.M. and F. Harianto, 1992, Technological networking and innovation implementation, Organization Science, 3, pp. 356-382.

Penrose, E.T, 1959, The theory of the growth of the firm, Basil Blackwell Publisher, London.

Perry-Smith, J.E. and C.E. Shalley, 2003, The social side of creativity: a static and dynamic social network perspective, Academy of Management Review, 28, pp. 89-106.

Pisano, G.P., 1989, Using equity participation to support exchange: evidence from the biotechnology industry, Journal of Law, Economics, and Organization, 5, pp. 109-126.

Plasschaert, S. and D. van den Bulcke, 1992, Changing dynamics of international production: globalisation and collaborative schemes in multinational enterprises, in: Broeck, Van den J. and D. van den Bulcke (eds.), Changing economic order, Wolters-Noordhoff Publishers, Groningen.

Podolny, J.M. and T.E. Stuart, 1995, A role-based ecology of technological change, American Journal of Sociology, 100, pp. 1224-1260.

Podolny, J.M., Stuart, T.E., and M.T. Hannan, 1996, Networks, knowledge, and niches: competition in the worldwide semiconductor industry, 1984-1991, American Journal of Sociology, 102, pp. 659-689.

Porter, M.E., 1981, The contributions of industrial organization to strategic management, Academy of Management Review, 6, pp. 609-620.

Porter, M.E., 1987, From competitive advantage to corporate strategy, Harvard Business Review, May-June, pp. 43-59.

Powell, W.W., Koput, K.W. and L. Smith-Doerr, 1996, Interorganizational collaboration and the locus of innovation: Networks of learning in biotechnology, Administrative Science Quarterly, 41, pp. 116-145.

Powell, W.W., Koput, K.W., Smith-Doerr, L. and J. Owen-Smith, 1999, Network position and firm performance: organizational returns to collaboration in the biotechnology industry, in: Andrews, S.B. and D. Knoke (eds.), Networks in 
and around organizations, research in the sociology of organizations, JAI Press, Greenwich (CT), pp. 129-159.

Primo Braga, C.A., Fink, C. and C. Paz Sepulveda, 2000, Intellectual property rights and economic development, World Bank discussion paper no. 412, The World Bank, Washington DC.

\section{$\mathbf{R}$}

Rao, H., Davis, G.F. and A. Ward, 2000, Embeddedness, social identity, and mobility: why firms leave the NASDAQ and join the New York Stock Exchange, Administrative Science Quarterly, 45, pp. 268-292.

Rapp, R.T. and R.P. Rozek, 1990, Benefits and costs of intellectual property rights protection in developing countries, Journal of World Trade, 24, pp. 75-102.

Ring, P. and A. van de Ven, 1992, Structuring cooperative relationships between organizations, Strategic Management Journal, 13, pp. 483-498.

Ring, P.S. and A.H. van de Ven, 1994, Developmental processes of cooperative interorganizational relationships, Academy of Management Review, 19, pp. 90-118.

Rosenkopf, L. and A. Nerkar, 2001, Beyond local search: boundary-spanning, exploration, and impact in the optical disk industry, Strategic Management Journal, 22, pp. 287-306.

Rowley, T., Behrens, D. and D. Krackhardt, 2000, Redundant governance structures: an analysis of structural and relational embeddedness in the steel and semiconductor industries, Strategic Management Journal, 21, pp. 369-386.

Ruef, M., 2002, Strong ties, weak ties and islands: structural and cultural predictors of organizational innovation, Industrial and Corporate Change, 11, pp. 427-449.

\section{$\mathbf{S}$}

Saggi, K., 2000, Trade, foreign direct investment, and international technology transfer, Policy research working paper 2349, The World Bank, Washington DC.

Sampson, R.C., 2004, The cost of misaligned governance in R\&D alliances, Journal of Law, Economics and Organization, 20, pp. 484-526.

Saxton, T., 1997, The effects of partner and relationship characteristics on alliance outcomes, Academy of Management Journal, 40, pp. 443-461.

Scherer, F.M., 1984, Using linked patent and R\&D data to measure interindustry technology flows, in Griliches, Z. (ed.), R\&D, patents and productivity, University of Chicago Press, Chicago, pp. 417-464.

Scherer, F.M., and D. Ross, 1990, Industrial market structure and economic performance, Houghton Mifflin Company, Boston.

Schilling, M.A. and H.K. Steensma, 2001, The use of modular organizational forms: an industry-wide analysis, Academy of Management Journal, 44, pp. 11491169.

Seyoum, B., 1996, The impact of intellectual property rights on foreign direct investment, Colombia Journal of World Business, 31, pp. 50-59. 
Shan, W., Walker, G. and B. Kogut, 1994, Interfirm cooperation and startup innovation in the biotechnology industry, Strategic Management Journal, 15, pp. 387-394.

Simsek, Z., Lubatkin, M.H. and S.W. Floyd, 2003, Inter-firm networks and entrepreneurial behaviour: a structural embeddedness perspective, Journal of Management, 29, pp. 427-442.

Smarzynska, B.K., 2002, The composition of foreign direct investment and protection of intellectual property rights, Policy research working paper 2786, The World Bank, Washington DC.

Soh, P.H., 2003, The role of networking alliances in information acquisition and its implication for new product performance, Journal of Business Venturing, 18, pp. 727-744.

Spence, A.M., 1984, Cost reduction, competition, and industry performance. Econometrica, 52, pp. 101-121.

Stuart, T.E., 1998, Network positions and propensities to collaborate: an investigation of strategic alliance formation in a high-technology industry, Administrative Science Quarterly, 43, pp. 668-698.

Stuart, T.E., 1999, Technological prestige and the accumulation of alliance capital, in: Leenders, R. Th. A.J. and S. Gabbay (eds.), Corporate social capital and liability, Kluwer, Boston, pp. 376-389.

Stuart, T.E., 2000, Interorganizational alliances and the performance of firms: a study of growth and innovation rates in a high-technology industry, Strategic Management Journal, 21, pp. 791-811.

Stuart, T.E. and J.M. Podolny, 1996, Local search and the evolution of technological capabilities, Strategic Management Journal, 17, pp. 21-38.

Summers, R. and A. Heston, 1991, The Penn world table (mark 5): an expanded set of international comparisons, 1950-1988, Quarterly Journal of Economics, 106, pp. 327-368.

$\mathbf{T}$

Teece, D.J., 1986, Profiting from technological innovation: implications for integration, collaboration, licensing and public policy, Research Policy, 15, pp. 285-305.

Teece, D.J., 1987, Profiting from technological innovation: the implications for integration, collaboration, and public policy, in Teece, D.J. (ed.), The competitive challenge, Ballinger, Cambridge (MA).

Teece, D.J., 1992, Competition, cooperation, and innovation: organizational arrangements for regimes of rapid technological progress, Journal of Economic Behavior and Organization, 18, pp. 1-25.

Teece, D.J., 1996, Capturing value form technological innovation: integration, strategic partnering, and licensing decisions, in: Tushman, M.L. and P. Anderson (eds), Managing Strategic Innovation and Change, Oxford University Press, New York, pp. 287-306. 
Teece, D.J., Pisano, G., and Shuen, A., 1997, Dynamic capabilities and strategic management. Strategic Management Journal, 18, pp. 509-533.

Tsai, W., 2001, Knowledge transfer in intra-organizational networks: effects of network position and absorptive capacity on business unit innovation and performance, Academy of Management Journal, 44, pp. 996-1004.

$\mathbf{U}$

Uzzi, B., 1996, The sources and consequences of embeddedness for the economic performance of organizations: the network effect, American Sociological Review, 61, pp. 674-698.

Uzzi, B., 1997, Social structure and competition in interfirm networks: the paradox of embeddedness, Administrative Science Quarterly, 42, pp. 35-67.

V

Van de Ven, A.H., 1986, Central problems in the management of innovation, Management Science, 32, pp. 590-607.

Varsakelis, N.C., 2001, The impact of patent protection, economic openness and national culture on R\&D investment: a cross-country empirical investigation, Research Policy, 30, pp. 1059-1068.

W

Walker, G., Kogut, B. and W. Shan, 1997, Social capital, structural holes, and the formation of an industry network, Organization Science, 8, pp. 109-125.

Wasserman, S. and K. Faust, 1994, Social network analysis: methods and applications, The Cambridge University Press, Cambridge.

Weimann, G., 1983, The strength of weak conversational ties in the flow of information and influence, Social Networks, 5, pp. 245-267.

Williamson, O.E., 1996, The mechanisms of governance, Oxford University Press, New York.

Winter, S.G., 1987, Knowledge and competence as strategic assets, in Teece, D.J. (ed.), The competitive challenge, Cambridge (MA), Ballinger.

Wooldridge, J.M., 2002, Econometric analysis of cross section and panel data, The MIT press, Cambridge.

$\mathbf{Y}$

Yu, C-M. J. and M-J. Tang, 1992, International joint ventures: theoretical considerations, Managerial and decision economics, 13, pp. 331-342.

$\mathbf{Z}$

Zaheer, A. and G.G. Bell, 2005, Benefiting from network position: firm capabilities, structural holes and performance, Strategic Management Journal, 26, pp. 809-825.

Zaheer, A. and S. Zaheer, 1997, Catching the waver: alertness, responsiveness and market influence in global electronic networks, Management Science, 43, pp. 1493-1509. 


\title{
Nederlandse samenvatting (summary in Dutch)
}

\section{De relatie tussen de vorming van onderzoek \& ontwikkeling (O\&O) allianties, sociale inbedding en innovatievermogen}

\author{
Een benadering van sociale inbedding op verschillende niveaus
}

\section{Introductie}

De verbetering van innovatie is een belangrijk onderdeel van de strategie van een (hoogtechnologisch) bedrijf en is nauw verbonden met haar alliantievorming op het gebied van onderzoek \& ontwikkeling (O\&O) en haar sociale inbedding (dat wil zeggen haar sociaal-economische context). Een belangrijke doelstelling van dit proefschrift is om het debat betreffende de verbanden tussen de vorming van O\&O allianties van een bedrijf, haar sociale inbedding en haar innovatievermogen te verbreden en te verrijken door de lange termijn effecten te analyseren.

De strategische management literatuur benadrukt het belang van kennis voor het creëren van een langdurig concurrentievoordeel. Kennis neemt een steeds belangrijkere rol in binnen het innovatieproces van (met name hoogtechnologische) bedrijven. Het is voor bedrijven moeilijker en kostbaarder geworden om zelfstandig kennis te ontwikkelen en uit te blinken op verschillende terreinen. Om te kunnen blijven inspelen op veranderende omstandigheden in de markt en nieuwe technologische mogelijkheden, en daarmee een concurrentievoordeel te creëren en te behouden, gaan bedrijven vaak hun kennis extern verwerven. Verwerving van externe kennis door middel van O\&O allianties is steeds belangrijker geworden in de afgelopen decennia. Door gebruik te maken van O\&O allianties kunnen bedrijven van elkaars verschillen leren, nieuwe ideeën en toepassingen verwerven, en nieuwe kennis en creatieve aansporingen voor innovatief gedrag verwerven.

In overeenstemming met de sociale netwerktheorie maakt dit proefschrift gebruik van een benadering van sociale inbedding op verschillende niveaus door een onderscheid te maken tussen omgevingsinbedding (op macro niveau in termen van het specifieke land en op meso niveau in termen van de industriële achtergrond), positionele inbedding (in termen van de historische achtergrond van het alliantienetwerk) en relationele inbedding (in termen van concrete één-op-één allianties). Deze benadering op verschillende niveaus zou ons kunnen helpen om een beter inzicht te verkrijgen in de mechanismen die O\&O allianties en het innovatievermogen van ondernemingen aansturen. De algemene onderzoeksvraag die aan dit proefschrift ten grondslag ligt luidt dan ook:

Wat is het verband tussen de vorming van $O \& O$ allianties van een bedrijf, haar sociale inbedding en haar innovatievermogen? 
Dit proefschrift tracht een antwoord te geven op de bovenstaande vraag door middel van kwantitatief onderzoek dat gebaseerd is op empirische analyses van de MERITCATI database (zie Appendix A). Echter, voordat we de algemene onderzoeksvraag kunnen beantwoorden is het van belang dat we een goed beeld krijgen van de verschillende niveaus van sociale inbedding. Hiertoe formuleren we de volgende onderzoeksvragen:

1. Wat is het effect van het macro niveau van omgevingsinbedding (in termen van de bescherming van intellectuele eigendomsrechten) en het meso niveau van omgevingsinbedding (in termen van de mate van technologische verandering in de industrie) op de voorkeur van bedrijven voor hiërarchische beheersing in een internationale $\mathrm{O} \& \mathrm{O}$ alliantie?

2. Wat zijn de effecten van de vorming van O\&O allianties, positionele inbedding en innovatievermogen op elkaar?

3. Wat is het effect van relationele inbedding (in termen van sterke en zwakke netwerkbanden van bedrijven) op het innovatievermogen van bedrijven?

Het onderscheid tussen omgevingsinbedding (op macro en meso niveau), positionele inbedding en relationele inbedding duidt op verschillende niveaus van sociale inbedding van bedrijven die zowel het gedrag als de prestaties van de bedrijven beïnvloeden. Meer in het bijzonder, spelen de verschillende niveaus van sociale inbedding een rol bij het verklaren van het gedrag van bedrijven in termen van hun voorkeur voor een bepaalde bestuursstructuur van internationale $\mathrm{O} \& \mathrm{O}$ allianties alsook in termen van de mogelijkheid om nieuwe $\mathrm{O} \& \mathrm{O}$ allianties te gaan vormen in de toekomst. Daarnaast spelen de verschillende niveaus van sociale inbedding ook een rol bij het verklaren van de prestaties van bedrijven in termen van hun innovatievermogen. In de volgende paragrafen wordt de rol van omgevingsinbedding, positionele inbedding en relationele inbedding onderzocht om een antwoord te geven op de algemene onderzoeksvraag.

\section{De rol van omgevingsinbedding}

Het eerste deel van het proefschrift gaat in op het effect van omgevingsinbedding op de voorkeur van een bedrijf voor hiërarchische sturing in een internationale O\&O alliantie. De strategisch management literatuur met betrekking tot de bestuursstructuur van gezamenlijke activiteiten, zoals gezamenlijke ondernemingen aan de ene kant en contractuele overeenkomsten aan de andere kant, legt de nadruk op drie hoofd onderwerpen: het toezicht op de daadwerkelijke samenwerking, de handhaving van contractuele voorwaarden, en de adequate specificatie van eigendomsrechten. De aspecten van besluitvorming met betrekking tot de wijze van bestuur voor samenwerking lijken zeer relevant voor het begrijpen van internationale O\&O allianties. Gezamenlijk O\&O, dat voornamelijk een belangrijke rol speelt binnen hoogtechnologische industrieën, is per definitie een onzekere activiteit waarvoor het 
zeer moeilijk, als niet onmogelijk is om ex ante zowel de volledige resultaten alsook de implicaties voor toekomstige activiteiten te bepalen.

Bovendien is het zo dat in het geval van internationale O\&O allianties de internationale aard van de samenwerking de onzekere aard van de activiteit alleen maar vergroot als gevolg van een gebrek aan vertrouwdheid met de omstandigheden in andere landen en omdat de handhaving van de contractuele voorwaarden voor internationale $\mathrm{O} \& \mathrm{O}$ samenwerking grotendeels van het specifieke rechtssysteem afhangt dat zulke samenwerking regelt. Het is alom bekend dat er grote internationale verschillen bestaan in overeenkomstenrecht, terwijl de daadwerkelijke handhaving van dit recht in vele landen zelfs helemaal niet bestaat. Voor dit onderzoek zijn de internationale verschillen in de bescherming van intellectuele eigendomsrechten het meest relevant. Volgens de literatuur is het zo dat hoe meer economisch ontwikkeld landen zijn, hoe vaker ze een rechtssysteem hebben opgezet dat overeenkomstenrecht handhaaft en hoe sterker hun bescherming van intellectuele eigendomsrechten is. Het bovenstaande wijst op een aantal belangrijke aspecten met betrekking tot de voorkeur van bedrijven voor internationale gezamenlijke ondernemingen en internationale contractuele overeenkomsten op het gebied van O\&O, in de context van internationale verschillen in de bescherming van intellectuele eigendomsrechten en de rol van technologische verandering in hun concurrerende omgeving.

Ten eerste, kan op basis van de literatuur verwacht worden dat, op het macro niveau van omgevingsinbedding, de sterkte van de bescherming van intellectuele eigendomsrechten in bepaalde landen zowel een belangrijke institutionele factor als een belangrijke omgevingsfactor zou moeten zijn in de keuzen die bedrijven maken wanneer ze internationale $\mathrm{O} \& \mathrm{O}$ allianties vormen. Bedrijven in landen die gekenmerkt worden door aanzienlijke bescherming van intellectuele eigendomsrechten worden geconfronteerd met hogere "appropriability gevaren" en eventueel daaropvolgende kosten als ze contractuele allianties aangaan met bedrijven in landen met relatief slechtere voorwaarden voor de bescherming van intellectuele eigendomsrechten. De verwachting is dat bedrijven in omstandigheden met dergelijke grotere "appropriability gevaren" kiezen voor internationale gezamenlijke ondernemingen omdat ze beheersing bieden op bestuurlijk en organisatorisch gebied, alsook mogelijkheden bieden voor adequate handhaving en toezicht. Ten tweede, mag volgens de literatuur verwacht worden dat, op het meso niveau van omgevingsinbedding, de mate van technologische verandering in industrieën van invloed kan zijn op de voorkeur voor een bepaalde bestuursstructuur van samenwerking door bedrijven. Snelle technologische veranderingen, technologische instabiliteit en technologische geavanceerdheid leiden tot de vorming van informele vormen van $\mathrm{O} \& \mathrm{O}$ samenwerkingsverbanden zoals contractuele overeenkomsten.

De uitkomsten van dit onderzoek (zie hoofdstuk 3) tonen aan dat de voorkeur van bedrijven voor hiërarchische sturing, door middel van een gezamenlijke ondernemingswijze voor internationale $\mathrm{O} \& \mathrm{O}$ samenwerking, omgekeerd verwant is met de sterkte van de intellectuele eigendomsrechtenbescherming in het land van herkomst van het partner bedrijf. Bovendien wijzen onze resultaten er op dat het 
vormen van internationale $\mathrm{O} \& \mathrm{O}$ allianties in industrieën die gekenmerkt worden door een grote mate van technologische verandering, de kans verlagen dat die samenwerkingsverbanden de vorm aannemen van internationale gezamenlijke ondernemingen.

\section{De rol van positionele inbedding}

Het tweede deel van het proefschrift gaat in op de onderlinge verbanden tussen de vorming van $\mathrm{O} \& \mathrm{O}$ allianties, positionele inbedding en innovatievermogen van bedrijven. Verwerving van externe kennis door middel van allianties is steeds belangrijker geworden in de afgelopen decennia. Door gebruik te maken van O\&O allianties kunnen bedrijven van elkaars verschillen leren, nieuwe ideeën en toepassingen verwerven, evenals nieuwe kennis en creatieve aansporingen voor innovatief gedrag verwerven. Naast de toename van één-op-één allianties zijn bedrijven ook in toenemende mate ingebed in netwerken van allianties. Netwerken zijn voor ondernemingen niet alleen van belang tijdens de start van de onderneming, de groei en de concurrentiepositie, maar zijn ook van belang bij innovatie en het vormen van nieuwe O\&O allianties. Een belangrijk kenmerk in dit opzicht is de centrale positie die een bedrijf inneemt binnen het alliantienetwerk aangezien dit de toegang tot informatie en daardoor de toegang tot externe kennis bepaalt. Bedrijven die een centrale positie innemen in een alliantienetwerk worden blootgesteld aan kennis van een groter aantal partner bedrijven alsook van een grotere verscheidenheid aan bedrijven, waardoor ze eerder in staat zullen zijn om hun innovatievermogen te verhogen. Bovendien hebben bedrijven in een centrale positie meer informatievoordelen die de mogelijkheid om nieuwe O\&O allianties te vormen zal verhogen. Deze informatievoordelen verminderen ook problemen met informatieasymmetrie die optreden bij het selecteren van partners, en maken het eenvoudiger om met nieuwe betrouwbare partners in contact te komen.

Op het niveau van positionele inbedding heeft de strategisch management literatuur de verschillende verbanden tussen allianties, positionele inbedding en innovatie bestudeerd, alhoewel de meeste studies de nadruk leggen op enkelvoudige oorzakelijke verbanden en daarvoor een specifieke dataset gebruiken. In hoofdstuk 4 hebben we empirisch de veelvoudige oorzakelijke verbanden tussen de vorming van $\mathrm{O} \& \mathrm{O}$ allianties, positionele inbedding en innovatievermogen geanalyseerd met behulp van één en dezelfde dataset. Ten eerste hebben we gekeken naar het effect van nieuwe O\&O allianties op het innovatievermogen van bedrijven. Vervolgens hebben we gekeken naar het effect van innovatie op het vormen van nieuwe O\&O allianties. Daarna hebben we gekeken naar het effect dat positionele inbedding heeft op innovatievermogen en de vorming van nieuwe O\&O allianties. Ten slotte hebben we gekeken naar het effect van het vormen van nieuwe O\&O allianties op de positionele inbedding van bedrijven. 
De uitkomsten van dit onderzoek (hoofdstuk 4) tonen aan dat de vorming van $\mathrm{O} \& \mathrm{O}$ allianties, positionele inbedding en innovatievermogen allen een positief effect op elkaar hebben. Niet alleen leidt de vorming van O\&O allianties tot hogere innovatie, die op haar beurt weer een stimulans is voor het aangaan van nieuwe O\&O allianties, maar de vorming van O\&O allianties zorgt ook voor een meer centrale samenhangendheid binnen een alliantienetwerk, die op haar beurt weer leidt tot het vormen van nieuwe $\mathrm{O} \& \mathrm{O}$ allianties alsook tot een beter innovatievermogen. Onze bevindingen ondersteunen het zogenoemde Matthew effect, dat verwijst naar een situatie waarin reeds innovatieve bedrijven constant hun innovatievermogen verder verbeteren door het vergroten van het aantal $\mathrm{O} \& \mathrm{O}$ allianties en hun positionele inbedding.

\section{De rol van relationele inbedding}

Op het niveau van relationele inbedding legt de strategisch management literatuur de nadruk op de rol die de sterkte van sociale banden speelt bij innovatie. Een gedeelte van de strategisch management literatuur verwacht dat zwakke netwerkbanden van bedrijven door middel van toegang tot diverse lokale netwerken en tot niet-overtollige informatie een meer divers informatieverzamelingproces zou kunnen vergemakkelijken. Blootstelling aan verschillende benaderingen en nieuwe perspectieven zou een bedrijf kunnen stimuleren om veranderingen in routines aan te brengen en te experimenteren met nieuwe mogelijkheden die haar bekwaamheden aanpassen en haar innovatievermogen verbeteren. Een ander gedeelte van de strategisch management literatuur daarentegen verwacht dat de sterke netwerkbanden van bedrijven betere resultaten opleveren dan de zwakke netwerkbanden van bedrijven. Sterke banden kunnen voordeel opleveren doordat ze netwerkspelers voorzien van een sterke sociale omgeving en wederzijdse steun. Bedrijven kunnen gebruik maken van hun sterke banden om voordeel te halen uit gezamenlijk leren en de overloopeffecten van kennis om op die manier hun innovatievermogen te verbeteren terwijl de verdubbeling van innovatieve inspanningen vermeden wordt.

In hoofdstuk 5 hebben we het effect van de sterkte van netwerkbanden op innovatievermogen onderzocht met behulp van een multidimensioneel perspectief bestaande uit drie factoren: de factor "omvang" (bestaande uit de dimensies "historische duur van de samenwerkingsverbanden van een bedrijf" en "aantal samenwerkingsverbanden van een bedrijf"), de factor "diepte" (bestaande uit de dimensies "intimiteit en wederkerigheid binnen een samenwerkingsverband" en "de overeenkomst in de sociale kringen van partners"), en de factor "culturele nabijheid" (bestaande uit de dimensies "binnenlandse vorming van samenwerkingsverbanden" en "internationale culturele nabijheid").

Onze resultaten (hoofdstuk 5) geven aan dat de factoren "omvang" en (vooral) "diepte" allebei een positief effect hebben op de innovatieve prestaties van bedrijven, dit komt overeen met een voorkeur voor sterke banden. De factor "culturele nabijheid" 
heeft een negatief effect op het innovatievermogen van bedrijven, wat het perspectief dat zwakke banden aanhangt ondersteunt. Bedrijven kunnen dus het beste een combinatie van sterke (in termen van omvang en diepte) en zwakke (in termen van cultureel, internationaal van afstand zijnde) banden vormen met hun partners.

\section{Antwoord op de algemene onderzoeksvraag}

In dit proefschrift onderstrepen we het belang van een geïntegreerde beschouwing van de verschillende niveaus van sociale inbedding bij het verklaren van zowel het gedrag van bedrijven als de prestaties van bedrijven. Met betrekking tot het gedrag van bedrijven kunnen we concluderen dat omgevingsinbedding (zowel op macro als op meso niveau), alsook positionele inbedding een belangrijke rol spelen in de keuze van de bestuursstructuur van nieuwe internationale $O \& O$ allianties alsook in termen van de mogelijkheid om nieuwe $\mathrm{O} \& \mathrm{O}$ allianties te gaan vormen in de toekomst. Op het macro niveau van omgevingsinbedding kan gezegd worden dat hoe groter de verschillen zijn in de bescherming van intellectuele eigendomsrechten tussen het land van herkomst van het bedrijf zelf en dat van haar partner, hoe eerder bedrijven een voorkeur hebben voor internationale gezamenlijke ondernemingen. Op het meso niveau van omgevingsinbedding zien we dat hoe hoger de mate van technologische verandering is in de industrie waarbinnen de alliantie plaatsvindt, hoe eerder bedrijven een voorkeur hebben voor internationale contractuele overeenkomsten. Op het niveau van positionele inbedding kan geconcludeerd worden dat hoe centraler de positie is die bedrijven innemen in een alliantienetwerk, hoe eerder deze bedrijven nieuwe O\&O allianties zullen aangaan.

Daarnaast is het zo dat we kunnen concluderen dat zowel positionele inbedding alsook relationele inbedding een belangrijke rol spelen bij de verklaring van de prestaties van bedrijven in termen van innovatievermogen. Op het niveau van positionele inbedding kan gezegd worden dat de vorming van O\&O allianties niet alleen leidt tot hogere innovatie, die op haar beurt weer een stimulans is voor het aangaan van nieuwe $\mathrm{O} \& \mathrm{O}$ allianties, maar dat de vorming van $\mathrm{O} \& \mathrm{O}$ allianties ook zorgt voor een meer centrale samenhangendheid binnen een alliantienetwerk, dat op haar beurt weer leidt tot het vormen van nieuwe O\&O allianties alsook tot een beter innovatievermogen. Op het niveau van relationele inbedding kunnen we concluderen dat sommige aspecten van sterke netwerkbanden een positief effect hebben op innovatie, aangezien de daadwerkelijke sterkte van omvang- en diepte gerelateerde dimensies het innovatievermogen van bedrijven bevorderen. Echter, sommige aspecten van zwakke netwerkbanden hebben ook een positief effect op het innovatievermogen van bedrijven, aangezien zwakke, cultureel en internationaal op een afstand zijnde, netwerkbanden het organisatorisch leren tussen bedrijven en daarmee het innovatievermogen van bedrijven bevorderen.

Concluderend kunnen we stellen dat bedrijven bij het maken van strategische beslissingen moeten zorgen voor een geïntegreerde beschouwing van de verschillende 
niveaus van sociale inbedding, aangezien deze een rol spelen bij het verklaren van het gedrag van bedrijven in termen van hun voorkeur voor een bepaalde bestuursstructuur van internationale $\mathrm{O} \& \mathrm{O}$ allianties alsook in termen van de mogelijkheid om nieuwe O\&O allianties te gaan vormen in de toekomst. Daarnaast is het zo dat de verschillende niveaus van sociale inbedding ook een rol spelen bij het verklaren van de prestaties van bedrijven in termen van innovatievermogen. 


\section{Curriculum Vitae}

Daniëlle (Anna Maria) Cloodt was born on November $20^{\text {th }}, 1976$ in Heerlen, the Netherlands. She attended grammar school at the Sintermeerten College in Heerlen, where she graduated in 1995. In the same year she started her study Economics at the Faculty of Economics and Business Administration at Maastricht University. She specialized in Money and Banking and obtained her Master's Degree in 2000. During her study she worked as a mathematics tutor at the department of Quantitative Economics and as a student assistant of prof. dr. J.G.A. van Mierlo at the department of Economics. After her graduation, she started working as a lecturer at the department of Economics. In September 2002, she started her Ph.D. research at the Maastricht research school of Economics of Technology and Organizations (METEOR) at the department of Organization \& Strategy. Since the $1^{\text {st }}$ of September 2006 she is working as an Assistant Professor at the department of Strategy \& Marketing at the Nijmegen School of Management at the Radboud University Nijmegen. Her main research interests include social embeddedness of firms, network analysis, strategic technology alliances, international strategy, technological change and innovation.

Daniëlle (Anna Maria) Cloodt werd geboren op 20 november 1976 te Heerlen. Zij doorliep het Lyceum aan het Sintermeerten College in Heerlen en behaalde in 1995 haar diploma. In hetzelfde jaar begon zij met haar studie Algemene Economie aan de Faculteit der Economische Wetenschappen en Bedrijfskunde van de Universiteit Maastricht. Zij specialiseerde zich in het Geld- en Bankwezen en behaalde haar Doctoraal examen in 2000. Tijdens haar studie werkte ze tevens als wiskunde-tutor bij de afdeling Kwantitatieve Economie en als student-assistent van prof. dr. J.G.A. van Mierlo bij de afdeling Algemene Economie. Na het behalen van haar diploma werkte ze als docent bij de afdeling Algemene Economie. In september 2002, begon zij als assistent-in-opleiding, verbonden aan de facultaire onderzoeksschool METEOR, bij de afdeling Organisatie \& Strategie. Sinds 1 september 2006 is zij werkzaam als universitair docent bij de afdeling Strategie \& Marketing aan de Faculteit der Managementwetenschappen van de Radboud Universiteit Nijmegen. Haar onderzoeksinteresses liggen op het gebied van sociale inbedding van bedrijven, netwerkanalyse, strategische technologische allianties, internationale strategie, technologische verandering en innovatie. 